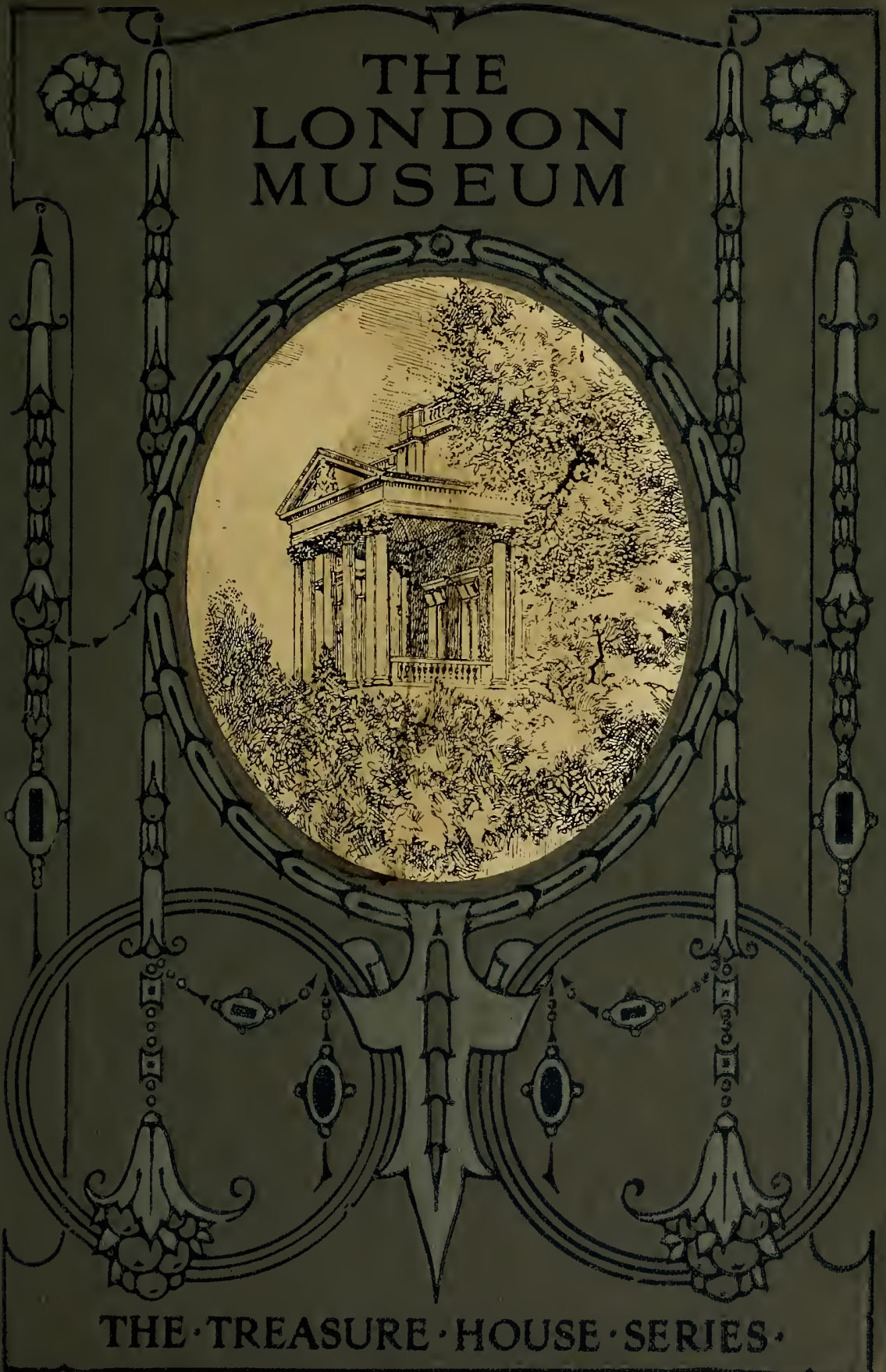






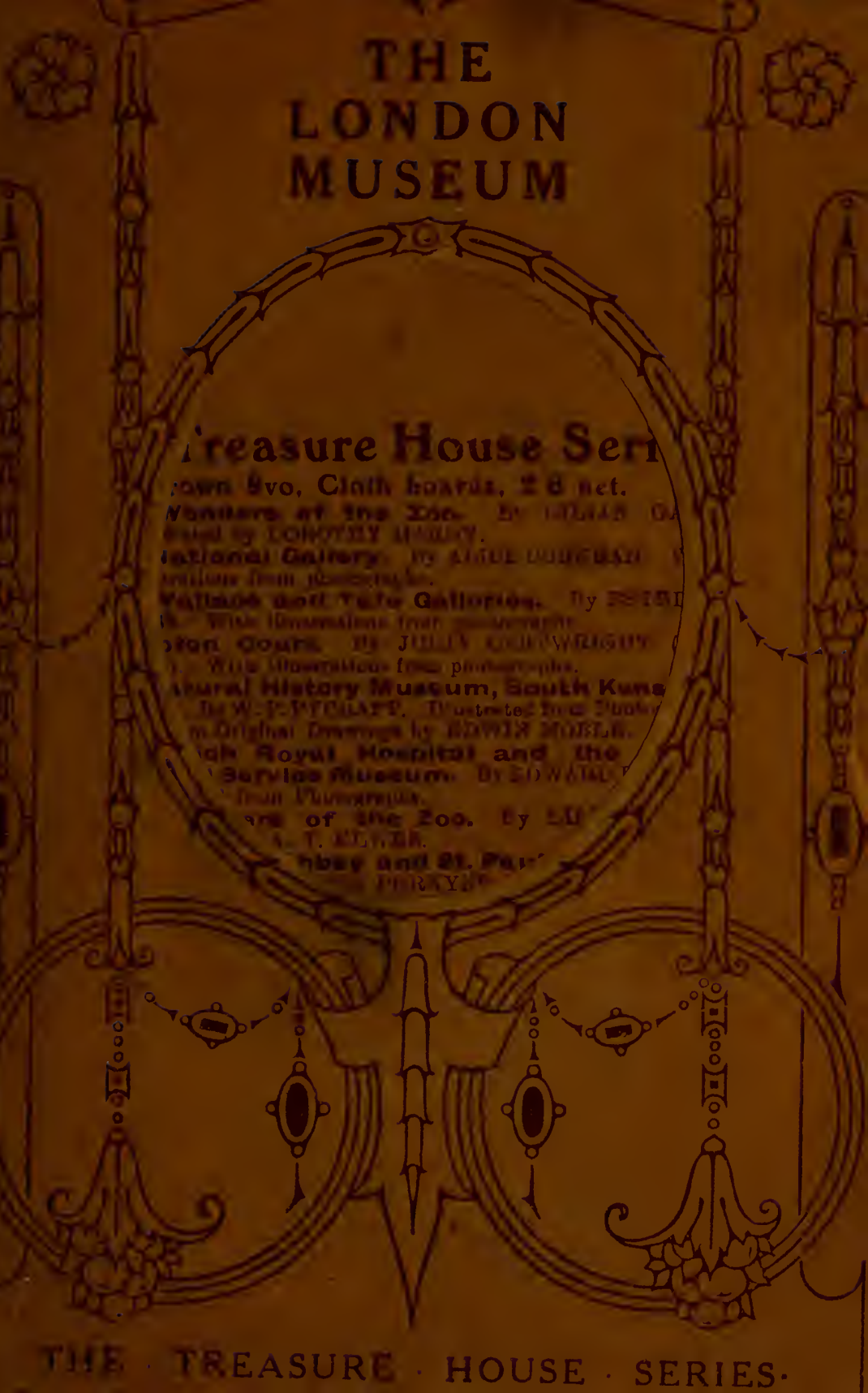




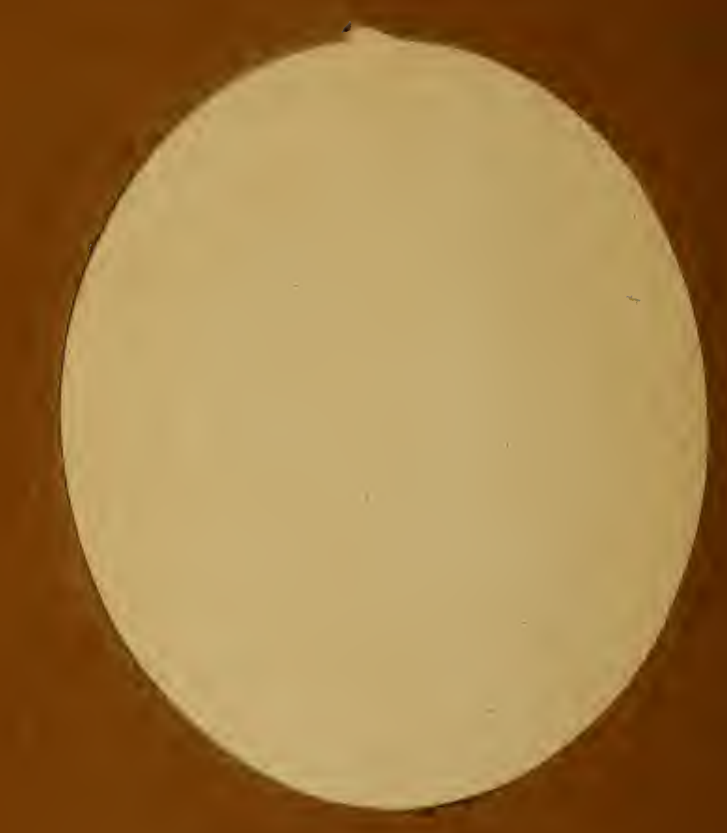


The Treasure House Series.

Erawe 0re, Cindi bosmil, 2 is net.

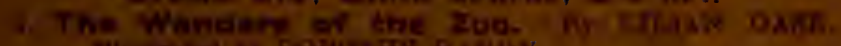

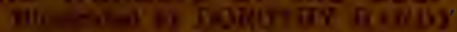

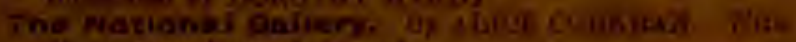

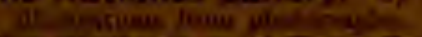

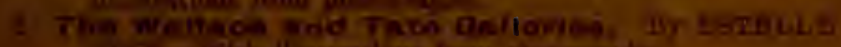

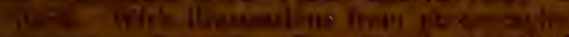

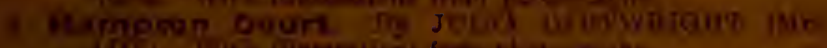

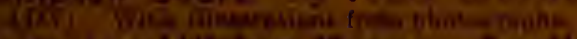

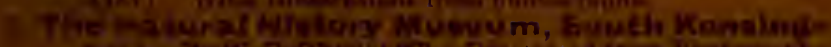

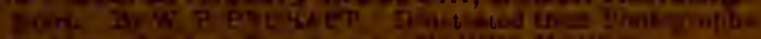

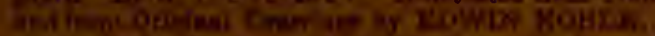

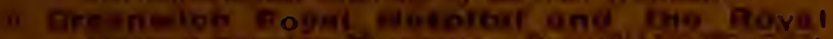

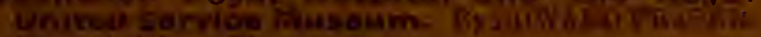

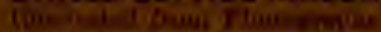

fint wowose of the zoo. IY LDLAN EAas.

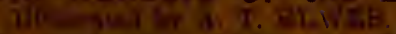

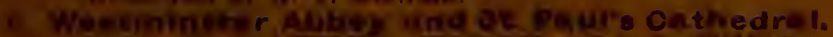

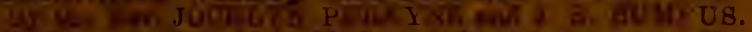

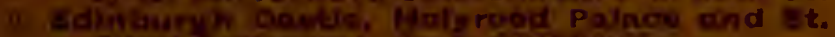

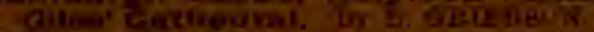

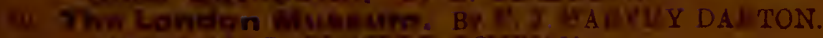
110, 
1 




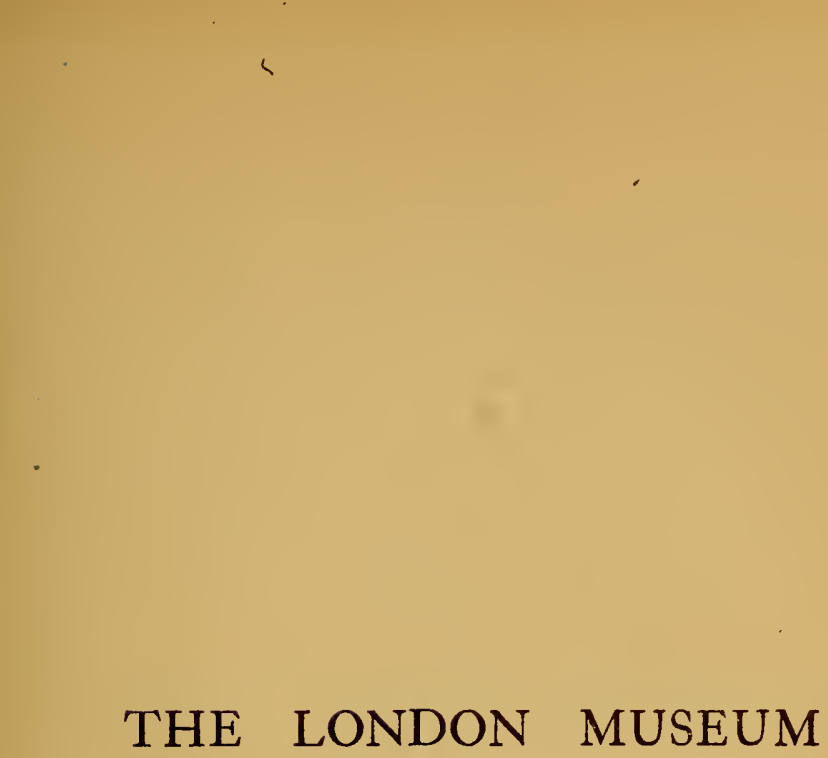

$+2$

\section{THE LONDON MUSEUM}






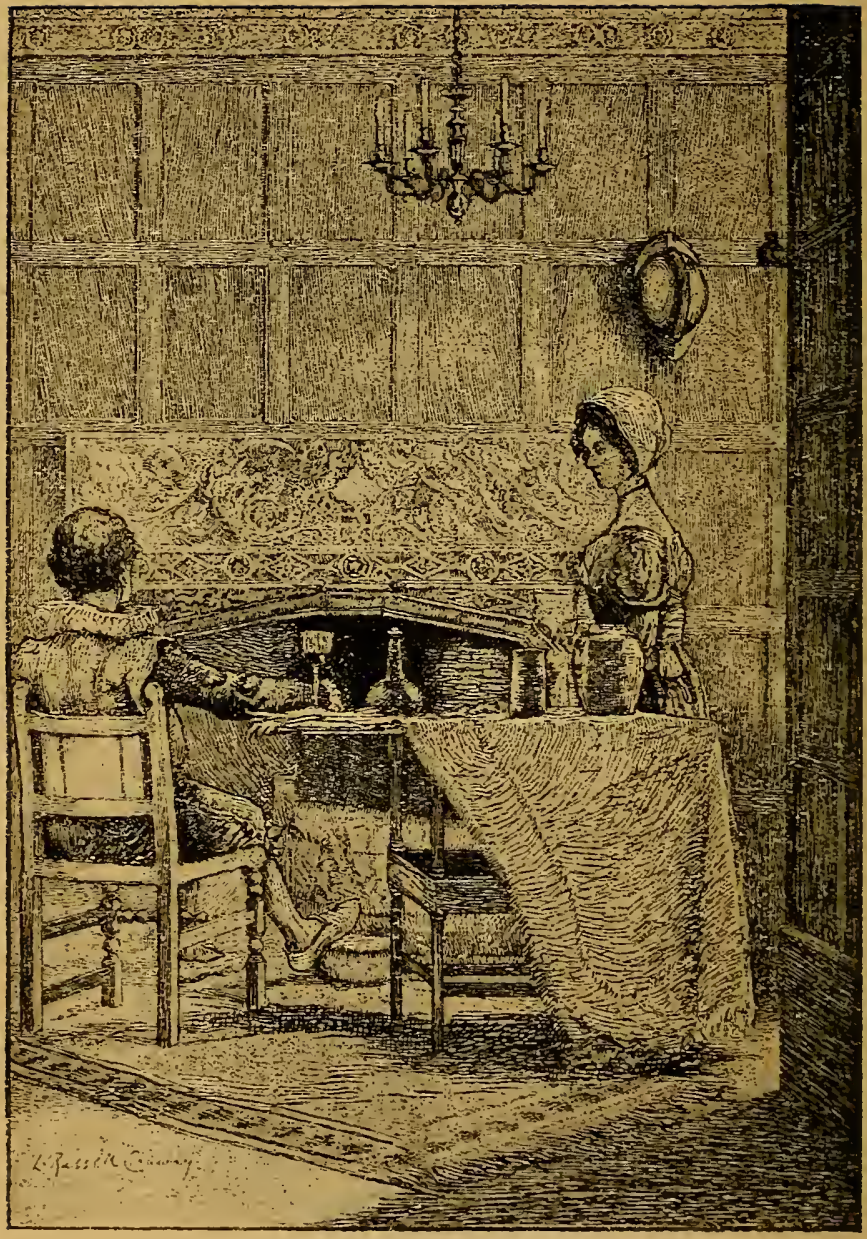

The Stuart Parlour 


\section{THE}

\section{LONDON MUSEUM}

BY

F. J. HARVEY DARTON

ILLUSTRATED BY L. RUSSELL CONWAY

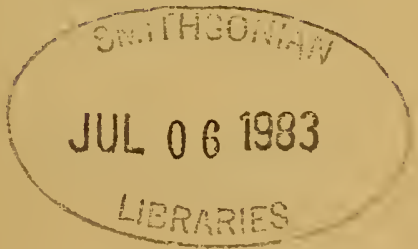

- LONDON

WELLS GARDNER, DARTON \& CO. LTD.

3 \& 4, PATERNOSTER BUILDINGS, E.C. . AND 44, VICTORIA STREET, S.W. 


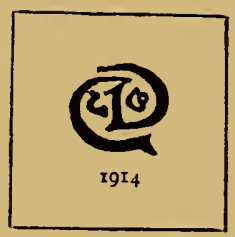




\section{INTRODUCTION}

LANCASTER House was opened as the London Museum in the spring of rgr4. It is situated at the western end of Pall Mall, past St. James's Palace and St. James's Street and Cleveland Row, in the direction of Buckingham Palace and the Green Park, to which there is a footpath from the square in front of the house. This square, named Stable Yard, is really part of the grounds of St. James's Palace; and Lancaster House itself is on the site of a former royal building, the Queen's Library, erected in the reign of George I.

Until it became the London Museum, Lancaster House was known as Stafford House, by which name it was famous for half a century as the most magnificent private house in London. It is, perhaps, gorgeous rather than beautiful in its internal decorations; but as a building suited to great receptions and imposing social functions it was unique. It is said that when Queen Victoria came to it from Buckingham Palace, she remarked to her hostess, the Duchess of Sutherland, "I have come from my house to your palace." The outside portico, the spacious entrance hall and staircase, and the fine suite of communicating rooms on the first floor, vii 
in which the collections of china and costume are now exhibited, are the most striking features.

Stafford House was built for the Duke of York, the second son of George III, by Benjamin Wyatt (the architect of Drury Lane Theatre); but the Duke died before it was fully completed, and in I84I the house was sold to the second Duke of Sutherland, in whose family's possession it remained till I9I2. Sir Charles Barry was employed to add the upper storey to it, and he also designed the internal arrangements. It is said that over $£ 250,000$ was spent on it.

In I9I2, Sir William Lever, the well-known soap manufacturer, and founder of the model village of Port Sunlight, purchased the house, and in June I9I3 presented it to the nation as a home for the London Museum, the collections of which had hitherto (from April I9I2) been on view in the State apartments of Kensington Palace. The collections, partly the results of munificent private gifts, and partly purchased by official funds vested in trustees, were first got together in IgII, but have been immensely enlarged since then. The foundation of the Museum was chiefly due to the Rt. Hon. Lewis Harcourt, in IgII First Commissioner of Works ; and to the first and present Keeper, Sir Guy Laking, Bart., C.B., M.V.O., its comprehensiveness and excellent organisation are largely to be attributed.

Lancaster House is splendidly adapted to the needs of a museum, and the collections are displayed with a thoroughness, clearness, and skill unsurpassed in 
any public exhibition of the kind. The Museum is, for all practical purposes, arranged in chronological order (which this book follows); it begins with prehistoric man, and ends, at present, with the Coronation robes of King George V. That simple statement shows at once what a good museum should be, and what a story London can tell. A museum contains dead things : but if we use it rightly, they are no more dead than a man is dead when his mortal life is ended. Everything in Lancaster House, every stone, every garment, every tool and weapon, even the forlorn little toys of other ages, represents some ideal, some hope or some passing thought, of our forefathers. They made this out of vanity, or that out of love; they did this to earn a living, or that to fight for one unlawfully. Some were kings, some rebelled against kings ; some were just ordinary men going about their business cheerfully, or unhappily, or lazily, as we do : of the greater part not so much as their name is known. But high or low, humble or ambitious, they lived and worked in a city the like of which is not to be found in the whole world to-day, nor has been seen in all the history of mankind. They made London-all of them, not the great ones only. We in our turn have to make the London of to-morrow. When. we look back here on the past, and see how its life has changed and grown from generation to generation, we can try to understand how, centuries hence, other men will look back on what we have achieved and what we have left undone ; and with humility and yet with pride we can strive to make it sure 
that they look back on nothing unworthy of the capital of England.

The aim of this book, then, is to provide a " guide, philosopher, and friend" to persons who do not always know, or want to know, everything in the minutest and most exact detail; to interpret, rather than to catalogue, a museum which is designed to re-create the immemorial life of a great city: though it is hoped that the enumeration of particular objects has omitted nothing of value or interest from any other point of view. It is not intended to record sale-prices or the rarity of "antiques" ; nor is it meant to encourage the misuse of the words "quaint" and "old-world," by the disappearance of which English popular history would be vastly enriched. It is, in a sense, an outline of the story of London; and yet, since the Museum has certain natural limitations, it is not an entirely complete story (the Museum, for instance, contains no relic of the "commune," or of Charles I's quarrel with the City). In the same way, it is not, and could not be, an encyclopædia of all the multitudinous subjects suggested or covered by the Museum. It can only select types and indicate tendencies.

There is very little difficulty of grasping the arrangement of the collection. On the left of the central hall is a passage running right and left, 


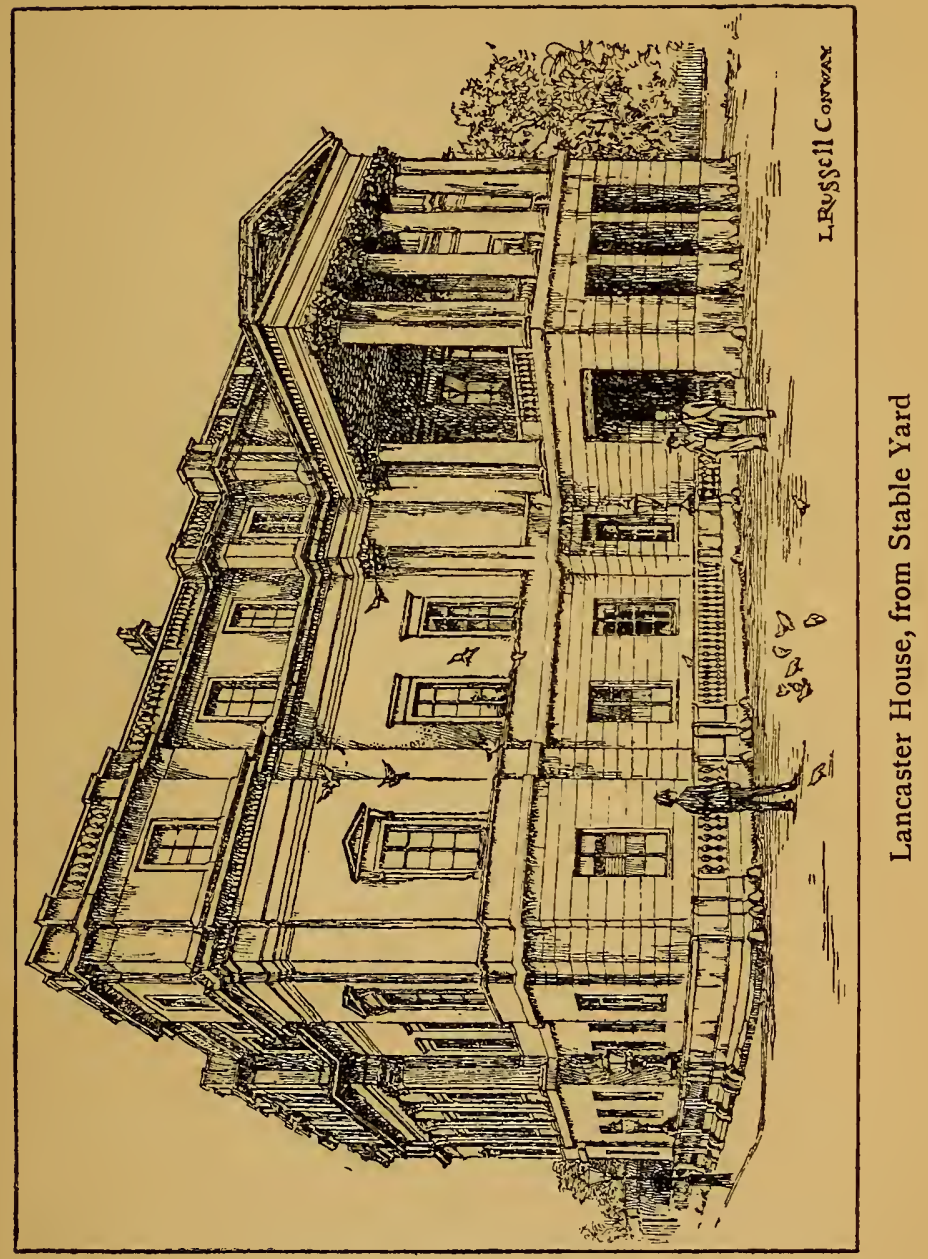



into which visitors are first directed by the attendants. On the right of this passage, on the ground floor, lie the rooms illustrating the earlier periods of London history. The first is the Palæolithic or Prehistoric Room, dealt with in Chapter I of this book. Opening out of it on the left is the Roman Room (Chapter II). This is a blind alley, and visitors must return and cross the Palæolithic Room to reach the Saxon and Early Norman Gallery or Corridor (Chapter III) - which is really part of a spacious room boarded off by screens. These three sections are illustrated also by certain objects shown in the Basement, which can be visited either first of all or last-or better still, both-because it contains exhibits bearing on the domestic life of London, and a large number of prints, which are an excellent introduction to the Museum and can at the same time be appreciated even more fully after the other sections have been seen. The chief objects of the periods up to I700 there displayed are mentioned in this book in the chapters dealing with their separate periods, with a note that they are to be found in the Basement: the eighteenth and nineteenth century objects, which are in a large majority, are treated in the chapter on the Basement.

The Saxon Gallery leads into a Mediæval Room (Chapter IV), and from this another "blind-alley" room opens, corresponding to the Roman Room. In it is grouped a wonderful collection of jewellery and plate, kept separate thus, out of chronological order, for obvious reasons of convenience. This, 
and a case of nineteenth-century jewellery on the first floor, are dealt with in Chapter V. Costumes (with a few small exceptions) are isolated in a similar manner, in a single group, on the first floor, and are also dealt with separately in Chapter XI.

From the Jewellery Room the visitor has to reenter the Mediæval Room, and leave it by a door that leads again to the Central Hall, and so up the right-hand half of the main staircase. From here till the long Gallery of Costumes is reached the rooms are arranged in clearly divided periods, beginning with the Tudor; each period is treated successively in Chapters VI to X.

The Basement, as has been said, contains objects illustrating, chiefly, London's domestic life, especially in the eighteenth century. It also contains certain things for which some special provision of space had to be made, like the Roman boat, Wellington's carriage, the Stuart parlour, and the prison cells. The last chapter (Chapter XIII) deals with these, so far as they have not been mentioned in earlier portions of the book.

The writer is very greatly indebted to the Keeper of the London Museum and his assistants for their courtesy and kindness in affording both artist and author facilities for this work, especially at a time when for public reasons the Museum was temporarily closed. 


\section{CONTENTS}

CHAP.

INTRODUCTION . . . . . . . vii

I. LONDON BEFORE THE ROMANS . . . ; I

II. The Roman Room • • . . . . $\quad$ I6

III. The Saxon and Norman Corridor $\quad$ - 32

IV. The Mediæval Room . . . . $\quad .48$

V. The Jewellery Room • • • • . 65

VI. The TUdor Room $\cdot \quad \cdot \quad \cdot \quad \cdot \quad \cdot \quad \cdot \quad 87$

VII. The Early Seventeenth Century and ComMONWEALTH ROOMS . . . . . IO6

VIII. The Late Seventeenth Century Room • - I2I

IX. The Joicey and other Collections of China r45

X. The Late Eighteenth and Nineteenth

Century Room . . . . . . 166

XI. The Costume Gallery $\underset{x v}{\operatorname{~}} \cdot \cdot_{b} \cdot \mathrm{I} 80$ 
CHAP.

XIII. The Basement . . . . . . . 2 2 I3

INDEX . . . . . . . . 247

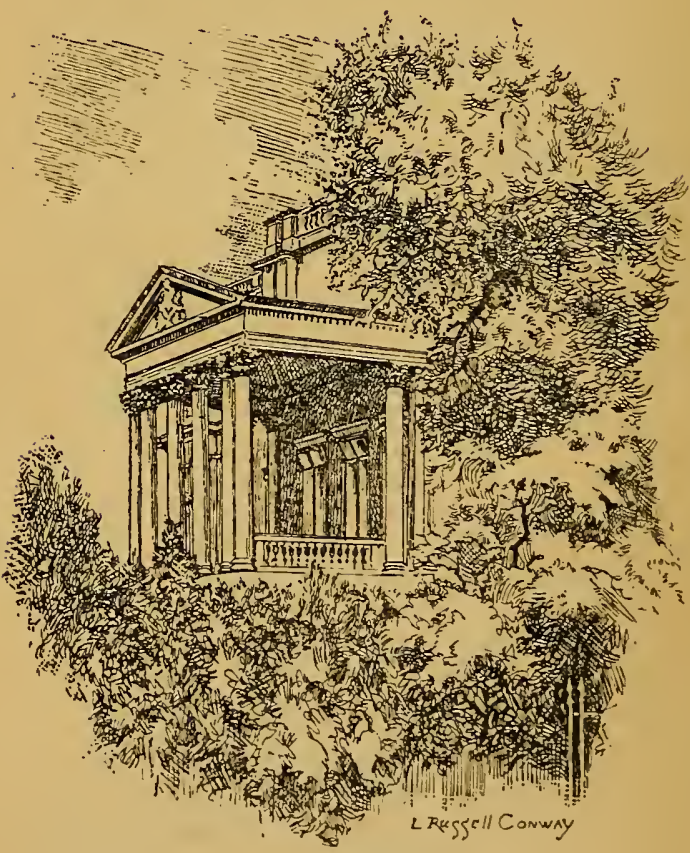

Lancaster HoUse, From the GReEN PARK 


\section{ILLUSTRATIONS}

The Stuart Parlour $\cdot$. $\quad . \quad$ Frontispiece

Lancaster House, from Stable Yard . . . xi

Lancaster House, from the Green Park • . xvi

Prehistoric "Dug-out" or Tree-trunk Canoe . I3

The Roman Bott . . . . . . . $2 \mathrm{I}$

Weapons of the Early Periods, and other Objects 49

Fifteen Centuries of Shoes . • • . . . 57

Jewellery of the Seventeenth and Nineteenth

Centuries • . . . . . . . . $8 \mathrm{I}$

Pedlar's Pack, Sixteenth Century - . . 9r

A Roman Glass Bottle, a Leather Jug, and Earth-

ENWARE JARS • • • • • • . 93

Oliver Cromwell's Gun · • . . . . . 119

The Seventeenth Century Rocking Horse . . I 30

Hats and Helmets of Four Centuries . . . I 33

"The Dancing Lesson" • . . . . E 150

The Georgian Doli's House • • . . . I6I 
OFFICER'S UNIFORM WORN AT THE BATTLE OF

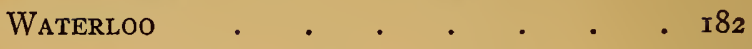
The Duke of Wellington's Post-chaise - . $\mathrm{I}_{3}$ The Georgian Toy-Shop • • . . • . 215 NEW INN DOORWAY . . . . . . . 2 I9 A London Grocer's Sign . . . . . . 219 PRISON RELICS . . . . . . . . 239 


\section{THE LONDON MUSEUM}

\section{CHAPTER I}

\section{LONDON BEFORE THE ROMANS}

THE oldest objects in the London Museum are two little yellow flints, roughly chipped to a more or less flat point, shown in a small framework of wood in the case on the right hand as the Palæolithic or Prehistoric Room is entered. They look as if they were just stones picked up by chance. As a matter of fact, they are the weapons of the first Londoners ; they were found deep in the ground; and they imply the whole story of how a city is born and grows.

If you leave a stone like one of these lying on the ground in the open air, in some place where the soil is not likely to be washed away by rains or streams, it will gradually be covered up, and become, as it were, part of the soil on which it rests. This burial of the stone will be due to various causes. First of all, there is always a certain amount of dust falling from the air, even if we cannot see it so plainly as when it is raised in a cloud on a road by a motor-car. The dust may be merely from the 
earth itself, blown into the air by some local wind. Or it may be, as it often is in London, minute particles of carbon, contained in the smoke of chimneys: if you catch some London rain-water in a clean bowl, you can see this carbon in it-the rain washes the air and carries the carbon to the ground. Or the dust may be "cosmic"-that is to say, the fine powder to which fragments of other stars, whirled violently through space, are reduced in their journey through our atmosphere to the surface of the earth.

The stone, then, may be slowly covered by dust : and thus the air does its part in burying it. Again, seeds borne by the wind, or dropped by the birds, may alight near it ; and when they take root and grow, they act as a sort of breakwater for the soil. They hold it and bind it together, and it silts up against them. The plants themselves, besides storing up earth by the stone, may cling to it with their roots, or grow over it. Thus the vegetable kingdom helps to build up the world over the stone.

Then there is the earth-worm always at work, casting up soil from beneath as he wriggles along on his underground journeys. And then there are insects-digger beetles and others-whose great work in life is to bury things they find lying on the ground. In country districts there are rabbits and moles as well to alter the surface. And so the animal kingdom covers the stone too.

Lastly, there is man, who cannot build his houses, of whatever material, without in some way marking 
and altering, however slightly, the soil upon which he dwells.

Now since the surface of the earth is being raised in this way, the oldest things that have formerly lain on the surface will be found now deepest beneath it. This room contains some of the oldest things in London ; and they (like a very large number of the objects shown in this Museum) have nearly all been found by digging, underneath the streets and houses of to-day; one little pointed implement in the right-hand case, for instance, was found beneath Piccadilly Circus. Roman London, to which we shall come in the next chapter, shows some of the most curious examples of this: in many places we are literally walking to-day upon the roofs of former men's houses.

That, then, is one way in which " our valiant dust builds upon dust." London has grown layer by layer. But the process is so long that it goes back more years than anyone can calculate exactly. The label on this case says that one scientist believes that the race of men who used these early stone weapons lasted 700,000 years; another, that they lasted a mere 139,000 years. When eolithic and palæolithic man-man, that is, of the dawning or earliest Stone Age, and of the Old Stone Age-when he made these instruments, London, of course, did not exist: there were no towns anywhere upon earth. England was not an island. It was joined to Europe, and where the North Sea and the English Channel now are, ran two enormous rivers: the Thames was a tributary of the North Sea River, 
which was a continuation of the present Seine and Rhone, and issued in a Northern Ocean far up towards Iceland and the North Cape. The other huge river ran westwards into the Atlantic beyond Cornwall.

Man was a very little creature in that strange world : very defenceless, very weak and miserable from our point of view, and yet very wonderful. These little chipped flints were his only weapons. On the wall on the left hand you can see how they could be mounted on stout sticks so as to become axes and hammers. It was probably long before that idea occurred to Stone Age man. In this righthand case are the remains of what the users of such weapons had to face-the skulls and other bones of huge beasts now extinct: and also the skull and the cast of a skull of palæolithic man himself. On the walls is a picture of a man encountering a mammoth: in the case are fragments of a mammoth, dug up in London. The mammoth was the terrible ancestor of the elephant. Near by are the skull and bones of Bos primigenius, the Father of Bulls: he was more like a bison or buffalo than our English bull of to-day. There was another kind of bull also, Bos priscus, the Ancient Bull: you can guess from his bones 'too' how powerful he was. There was a formidable rhinoceros whose bones lie here too. There were other beasts not showncave-lions, cave-bears, a monstrous tiger with long, curved, sword-like teeth projecting from his awful jaws, hippopotami, hyænas, and gentler creatures like deer. Man fished and hunted for a living (a wonderful little harpoon shows how he did his fish- 
spearing) : many a time he must have been hunted, in turn, for his life. He could not spin nor weave : he wore skins. He could not make even the roughest pottery. Till very late in the generations of palæolithic life, if at all, he could not make fire. He had no domestic animals: he knew the horse (or the horse's ancestor), but he did not ride or use horses for work: he ate them, seeming to prefer their flesh, very often, to that of other animals. The hyæna and whatever dog-like beasts there were were his enemies, not his friends or dependents. $\mathrm{He}$ was lower than the lowest savage known to-day, hardly better than the beasts he fought. But he was man : he could use weapons and tools: and these flints that look so feeble and useless are in one sense the most striking things in the history of mankind: they are the earliest sign that man could use means to ends, and raise himself above all other living things.

It is worth while mentioning here that the first flint implement ever dug up and recognised as a weapon was found in London, in Gray's Inn Lane, at the end of the seventeenth century. When, a hundred years later, scientists began to examine such finds more carefully, they realised that this weapon (now in the British Museum) was the first evidence of a previously unknown chapter in the history of mankind.

Now there is another point about many of the older objects in this room; and this concerns London in particular, as well as primitive man. London, as has been said, has grown higher and higher: but its shape and situation have been 
influenced in another way. When the Thames flowed into the North Sea River, and indeed much later, when it was an independent river flowing into the present North Sea, it must have looked very like the picture on the left-hand wall. It was a great marshy expanse, with a broad stream moving through it, constantly changing its course. It had many " drifts "- -little silted-up creeks and half-dry patches of land. Palæolithic man lived either in caves or in river drifts, whichever happened to be on the spot. In the case of London, he lived in river drifts. So the first association of man with the spot where afterwards the greatest city in the world was to arise, was with the river that, throughout history, has given that city its chief importance -London River, as sailors still call the Thames; and this river, bringing down earth and sand and stones from its source at higher levels, helped to build up the swampy land of London. In those swamps, with flints for weapons, the first Londoners fought for existence. They lived, apparently, in rough huts of wattle and skins. They must have been few and lonely, with little to bind them together-no laws, no commerce, no roads, nor other means of communication, no belongings or treasures other than what they could get (with great difficulty) for themselves.

They did not live only in huts. At the end of this Prehistoric Room, on the wall between the windows, are a few shrunken stakes, that look like worn-out fence palings. Their exact age is not known: but whether they themselves are of this 
oldest Stone Age, or much later, of the Celtic Bronze Age, they are examples of a kind of dwelling which was built very far back in the history of mankind. They are the stakes or supports of a pile-dwelling, or lake-village, sometimes called a crannog. They were found at Walthamstow. In the left-hand case is a flint axe found in the same place. Primitive man drove these palings into the river or marsh, and made a sort of mound with their aid: between he put any solid material, gravel or earth, which was available; and on top of the mound he set up his huts. Thus he made a kind of island fort, which could not be easily taken by surprise, and gave a look-out over the flat stretches of river. A picture on the wall shows what such a house was, though perhaps the people drawn are a little more picturesque than they really should be (whatever else he was, however brave and wonderful, prehistoric man would soon disgust his descendants if they could meet him alive) : and there is also a diagram of the structure of a lake village. Buildings like this are found in many parts of Europe, particularly in Switzerland. The finest in England is near Glastonbury, in Somerset, where many families must have lived till as late as Roman times.

So far we have considered only palæolithic man, our very oldest ancestor. $\mathrm{He}$ is not peculiar to England, and it cannot be said that he was of any particular race. So little is known about him that, though it can be proved (from skulls and weapons dug up in England, France, and elsewhere) that he gradually became more and more "civilised" (in 
a very rude sense), it is not possible to say much more about him than that he was man. Whether he came into " England " (which, it must be remembered, was not yet England, not yet an island) from east or south, why he disappeared, whether he died out altogether, or simply went away and came back later, cannot as yet be definitely settled. All that can be said for certain is that before England was an island, palæolithic man, whose pathetic weapons we can here look upon with pity and reverence, was living upon the Thames: that when, or before, the North Sea and the English Channel were joined, he apparently vanished: that after that tremendous alteration of the shape of Europe, another race of men, with different habits of life, was in England. The connection between the first and second races, if there was any, is not yet known. It may some day be discovered by those who dig up the deep-buried relics of the past : only a hint, very often, is needed to show that such and such a find is a sign of some great change - a new thing that yet is closely related to the old.

This second race is called neolithic man-man of the New Stone Age. The case on the left-hand side of the room is filled with remains of his period: and there is a whole row of flint implements which tells his story more plainly than words can. They run from left to right, and from a mere chipped stone to a most perfectly rounded and polished weapon. There is as great a gap between the worst and the best of them as there is between palæolithic and neolithic man. If you think out the processes by 
which an utterly ignorant man, with no books and very scanty inherited knowledge, would perfect a flint weapon, you will realise that the progress to perfection is infinitely long. Try to make one, even without polishing it : then think of the experiments and failures a savage must have had.

Neolithic man was much more advanced than his palæolithic forerunner. He lived on higher ground, not in caves or drifts. He built, at a late stage in his existence, huge earthen forts on the tops of hills : there was one once at Barking. He could weave, and make simple pottery: there are examples of his pottery in the left-hand case. He cultivated crops (corn and similar cereals), and he had domesticated animals; most of the more dangerous beasts, like the mammoth and the sabre-toothed tiger, were extinct in England by this time. $\mathrm{He}$ could use the bow and arrow, which shows an intelligence far higher than that of the man who used only hand- or striking weapons.

It cannot be said, even within a thousand years, when the second of the Stone Ages began. But it can be asserted that it ended, in England, roughly about I80o B.C.' It ended because man had made a great discovery-a discovery as important as his first use of weapons. He found out how to work in metals-how to mix tin and copper, so as to make bronze. The middle case in this room, and a case over the fireplace, show what his work was like. They show, too, what an enormous difference

1 This is the date, more or less generally accepted, given by the British Museum Guide to the Antiquities of the Bronze Agre. 
the new tools and the new methods must have made. Imagine a man with a flint axe lashed to a staff fighting a man with a keen, strong, cutting sword : imagine the change from cutting up your meat with a sharp stone: imagine the saving of time in making the implements when you had simply to pour molten metal into moulds (the moulds themselves have been discovered in some parts of England).

If you look more closely at the objects in the middle case you will notice several important points. (I) There is a hoard of copper ingots, and below it some currency bars-bars of metal (which, of course, was valuable) used as money. (2) Some of the objects are labelled as " of the Hallstatt type "Hallstatt is in the Austrian Alps, and a great find of early implements and similar objects was made there in $x 846$. Hallstatt objects are both of bronze and of iron, and very finely worked : they belong to a period when iron had partly but not quite entirely superseded bronze as the best metal for tools and weapons. (3) Some of the objects are called Celtic, and there are also pictures of a splendid Celtic shield and helmet, the originals of which are in the British Museum. One was found at Battersea, the other at Waterloo Bridge.

When you have noticed these three points, look at a group of objects on the wall near the left-hand door : it consists of stone, bronze, and iron weapons. All three stages have been found together at once.

Now consider what these facts mean. If stone, bronze, and iron were all in use at once, man must have been developing much more quickly than 
before. The old things had not got out of date, but the new inventions crowded in upon them: there was no longer one stolid, unchanging pattern, nor one universal material. If objects like those found at Hallstatt are also found in London (and in many other places), this new civilisation must have been widespread. If there was a currency, there must have been means of communicationthere must have been trade, for money is of no use except to exchange for valuable objects you do not already possess. If iron and bronze and copper were used in London, again, still more must there have been trade: iron and tin and copper ores are not found in London, and the metal has to be fetched from a distance. Trade means civilisation -a recognition of other people, an agreement as to the methods of trading, some means of understanding one another. In fact, mankind was no longer a collection of scattered savage families getting a hard living haphazard: it was becoming a collection of races or nations. The race which became dominant in England was the Celtic. We have at last reached the "ancient Britons."

There are a great many details to be learnt about the early history of the Celts, the founders of London (London is a pure Celtic name). Much is known about their movements before they reached Britain (Britain also is a Celtic name), and about their tribal organisation. Such matters, however, belong to larger subjects than the London Museum. The chief thing that concerns us now is that the civilisation of London, when first it comes into written 
history (the history of Rome, that is), was Celtic. When Cæsar landed in 55 B.C., the Celts had been here for many generations. Crossing from Europe into England with their better weapons, they had conquered the earlier (late stone age) race usually called Iberians : they had not necessarily driven them out or exterminated them, but they had apparently overrun them altogether. They were in every way a superior race. The swords and kelts (socketed axe-heads), pins, and other objects in the bronze and iron age cases are not merely good tools, well adapted for their purpose. They are beautiful. No one to-day could invent more beautiful shapes. If we could see them as they originally were, before rust and age ate into them, we should be surprised to find that not only had the Celts nothing to learn about the shape of their instruments, but that we have learnt from them and cannot better the teaching.

What their way of life was will be better treated when we reach the next invaders of Britain, in the Roman Room. We shall get there another contrast between old and new, another long stage in the growth of London. In this first room we have seen the people who dwelt on the banks of the Thames developing from half-animal savages, with a weak hold on life, into a civilised nation, secure against the struggle for bare existence, and fairly skilled in the arts of living.

There is an object of this early period not shown in this room. It is in the Basement. It is a "dugout " or canoe made of the trunk of a tree hollowed 
out (see illustration): savages in other parts of the world have used such boats almost until to-day. The exact age of this canoe is not known : but it

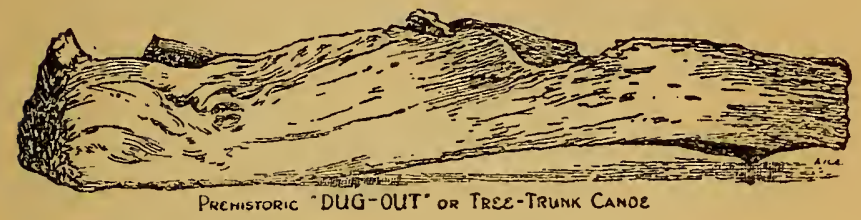

belongs to the period before the Romans came.

Do not leave this Prehistoric Room too quickly. It is easy to go on to objects which seem to be nearer the life of to-day. Men in later ages of history made things not very unlike what we make ourselves, but primitive man and his implements were utterly unlike anything of to-day. Yet those stones which seem, perhaps, so uninteresting and so unromantic are just what we should have shaped and used if we had lived then. Try, with only one very rough tool, and no experience, and no model, to make, say, a wooden box-try to make it in great discomfort, with interruptions. The result will not be much like a box turned out by a first-class carpenter. If you look at it in detail you will probably find it is utterly and ridiculously unlike a perfect box. You are a primitive box-maker. Primitive man had to face difficulties we simply cannot realise: his handicap was infinitely more arduous than that of a novice making a box to-day. $\mathrm{He}$ overcame the difficulties, and his victory is a thousand times greater than the failures we, countless 
centuries later, think we can see in his work. $\mathrm{He}$ is our forefather, whose labour made the world habitable for us: we shall be judged by later men, as he is judged, by victories over what we have to face, not by failures to achieve things not known to us.

This London of pre-Roman times, then, was a collection of islands in a marsh-islands that grew stronger by fortification and embankment, and forced the river into narrower and more regular channels. It is impossible to say what its boundaries were, or what its centre : probably the region now between Leadenhall Market and Ludgate Circus was the most populous and important district.

The Thames, by the time the Romans came, was very nearly the river we know, but probably broader. It had some tributaries which no longer exist-at least as rivers. The West-bourne (west river) ran from Hampstead along the course of the present Serpentine-which is the result of damming it : its course from the Serpentine onwards is now a drain. Tybourne also rose at Hampstead, and came down towards the Marble Arch (where Tyburn Tree, the place of execution, once stood), through the Green Park, where its valley can still be seen, and so to the Thames : the lake in St. James's Park is dammed from it. The Holbourne ran from Highgate to Blackfriars : it was called the Fleet in its later stages : it too is now a drain. Walbrook (a Saxon word-the brook of the Welsh, or Celts) ran along 
the street so named to-day, by the Mansion House. There were others, but these alone will concern us here.

Over the door of this Stone Age Room is an ornament which has a curious significance. It belongs to the great days of Stafford House as a private residence. It is a relief of Garibaldi, with an inscription in Italian saying that it commemorates his visit to the third Duke of Sutherland, in April 1864. Garibaldi was one of the greatest men of the nineteenth century: he, with other famous patriots, led his countrymen to set Italy free, and make her a nation. Many Englishmen fought by his side. The story of his life is a wonderful romance. Here his bust looks down on the beginnings of mankind ; and what he did was, in a way, a supreme achievement of mankind. Man is the only creature who can form an ideal, and fight and die for it. The story of these stones is the story of man's minda mind which after countless ages could set up, as Garibaldi did, the noble ideal of freedom. 


\section{CHAPTER II}

\section{THE ROMAN ROOM}

OLD histories of England used to begin with a plain statement that Julius Cæsar invaded Britain in 55 B.c., and found there savages painted with woad : as though England had hardly existed before then. Even now many people think of the Roman government of England mainly as a matter of roads which ran in straight lines across the country, and of embankments and ditches on hills, called camps. As a matter of fact, the Roman roads are often not straight, or not entirely straight; and nine out of ten " Roman camps" are not Roman at all, but are the work of the "ancient Britons" themselves, the Celts, or of the neolithic Iberians. The Celts, as we have learnt from the Prehistoric Room, had an immensely long history behind them before even the Romans came. They were not so comfortably or so thoroughly equipped as the Romans, certainly. They had wandered far, for many generations, and had not slowly built up, as the Romans did, enduring laws and a great system of civilisation. They were a less advanced race than the Romans: their weapons and armour were not so good (though Cæsar feared their terrible 
scythed chariots): they lived in wattle and mud huts, instead of stone houses : they were more cruel and less orderly-they made human sacrifices. They were split up, apparently, into small divisions, often warring upon one another. But they were not utter savages. And they already, when Cæsar came, knew something of the Roman Empire. They had close relations with the Celtic people of Gaul (France), who had become part of that Empire ; and one reason given by Cæsar for invading Britain was that his enemies in Gaul had a habit of crossing the Channel for a refuge whenever necessary.

Look now at a few of the chief objects in the Roman Room, and think what they imply. In a case on the left of the door, over the fireplace, is a collection of pottery. Some of it is quite simple, though well made: but some of it is smooth and red, and very finely finished. This is called Samian ware, from the Greek island (Samos) where it was first made in perfection. As a matter of fact the Samian ware found in Britain was probably made at Marseilles (Massilia), a city which, though in 55 B.c. and earlier it was a part of the Roman Empire, was originally a Greek colony. All these beautiful bowls, lamps, and so on were found in London: they are some of the most precious possessions of the Museum, for such good specimens of the ware are very uncommon. Then at the end of the room is a reproduction of a Roman pavement found in London (the original is elsewhere). To the right of it is a cast of a "Mithraic" group-a relief of the Eastern god, Mithras, slaying a bull : 
the original was found in Walbrook. Nearer the windows, on the far side of the room from the door, is a reproduction of a bronze head of the Emperor Hadrian, who reigned from A.D. II7 to I38. It is a fine strong piece of work, though a little heavy in style. The original is in the British Museum : it was found in the Thames at London Bridge. Just to the right of the door is a huge Roman amphora, or wine jar (see illustration of a similar jar, p. 49). Finally, there is a Roman glass bottle, excellently made (see illustration, p. 94).

Now for what these things tell us. The Samian ware means that it was worth while to import artistic objects into Britain from abroad, in great quantities (pottery ware is easily broken and destroyed, and so if it is found in many places, even in fragments, very much more than has survived to our day must originally have been in use). The country under Roman rule, therefore, was peaceful enough, and highly enough civilised, to need and use this ware plentifully. The great wine jar is an equally certain sign of civilisation-indeed, of wealth and luxury: so is the glass-Rome used glass as much as we do, and made it almost as well. The pavement proves that houses were built in London in the solid Roman fashion, not in the hut style of the Celts : that is to say, London was Romanised, and a place of some importance. If it were merely an obscure village, these and other signs of great and settled prosperity would not occur. The Mithras relief shows that the worship of this Eastern god, common all over the Roman Empire, had 
spread to Britain. If the Britons had not given up their Celtic gods, or become Christian, they were at any rate so far Romanised as to know something of this fashionable foreign religion. Finally, the bust of Hadrian suggests that Rome was recognised as the head of British civilisation-not the conqueror, but the central point of loyalty and power. That bronze head probably had for London just the same meaning as a statue of Queen Victoria would have to-day for Bombay.

All these facts could be inferred from a few objects in the Roman Room, even if that room itself did not give plenty more evidence to prove them, and if we did not know them also from written histories of the time. Now, before examining the other objects more closely, consider a little case of coins on the end wall on the left of the Roman pavement. They begin just before the Christian era. The first Roman emperor shown on them is Tiberius, grandnephew of Julius Cæsar; his head is on a splendid little gold coin. Next comes Claudius, under whom Britain was really conquered : in his reign Boadicea burnt London and died. There is a fine silver head of Hadrian, who built the great wall across the north of England to keep the frontier tribes of Picts at bay. There are later emperors like Constantine (who probably built London wall); and the series ends with Carausius (A.D. 286-293) and Allectus (A.D. 293-496), of whom we shall speak presently. The coins cover a period of over three hundred years: almost exactly the time that has passed since Shakespeare died. In that later 
period of three centuries, the Stuarts, the Commonwealth, the Revolution, the Hanoverians, the Victorian era, the reign of Edward VII, all with their diverse ideals and changes of outlook, succeeded one another. In the earlier period, Britain was Roman without a break: and London was no mean city of the Roman Empire. This little room, in fact, contains the few remains of an epoch which lasted as long as that which provides the objects shown on the whole first floor of the London Museum.

In the Basement are two important Roman objects (it is impossible to indicate exactly where they are shown-the passage must simply be followed till they are reached), which tell the same story of that great lapse of time. The first is a thick, driedup stake, lying under a window. It comes from the Thames near Brentford, and is believed to be one of a palisade of stakes placed at the ford there to prevent Cæsar from crossing the river to attack King Cassivellaunus in his own territory. Cæsar marched from the Kent coast to London in 54 B.C., and at Brentford the men of the London district gave him battle-in vain. That is the first Roman event in the history of London.

In the same room is the famous Roman boat, found in Igro when the foundations of the County Hall, south of Westminster Bridge, were being dug. That boat is almost a story in itself. It has been set up in Lancaster House in a wonderful way, so as to appear as it had lain for sixteen hundred years in the bed of the Thames-in the old bed, that is, 
before the river was embanked or had cut its middle channel deep enough to leave the banks partly dry. It was twenty-one and a half feet below the level

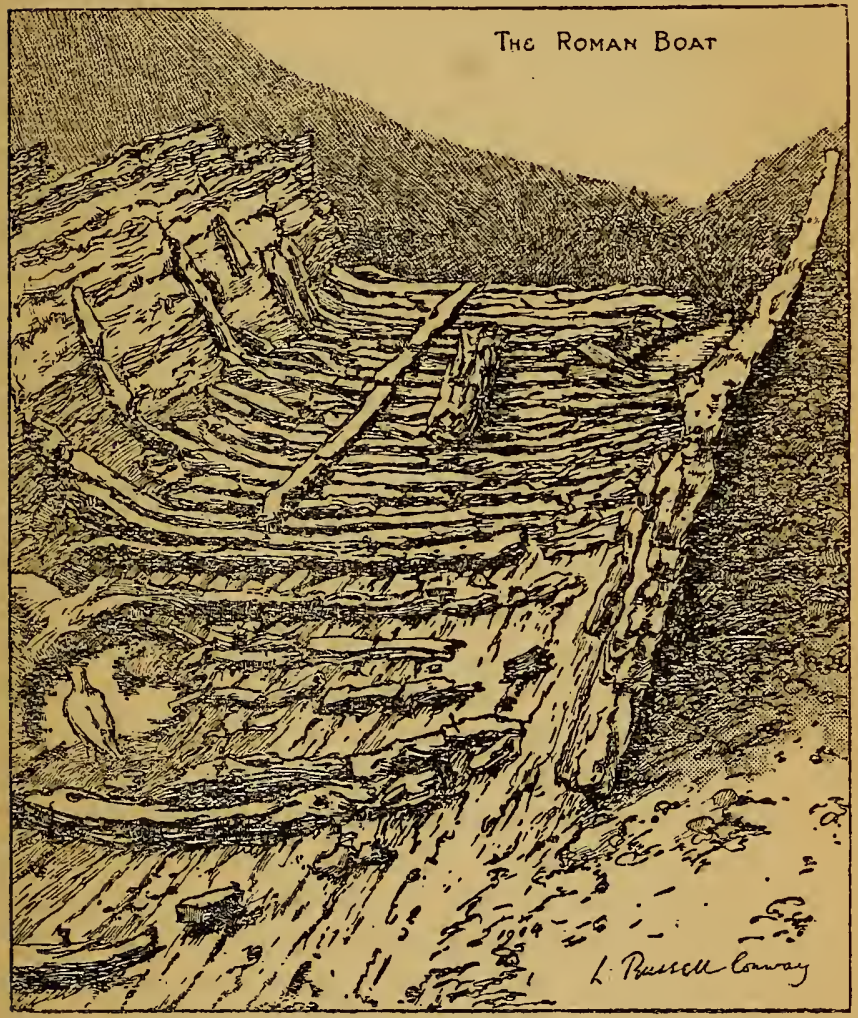

of the present roadway at the spot: most of Roman London was at least fifteen feet below the present surface--so that we are walking on top of it. 
Pictures on the walls show how the boat was dug out and packed, and how it made a triumphal progress, drawn by many horses, to the London Museum. The wall of the room in which it now rests had to be opened to accommodate it.

It is believed to be a ship of the fleet of Carausius, the first British sea-captain whose name is known to us. He was appointed, in the late years of the Roman Empire, to command a fleet which had been raised to repel the Saxon pirates, who even then were beginning to ravage the English coasts. Carausius was successful, and seems to have roused suspicion and jealousy of his power : at any rate, he rebelled against Rome, and proclaimed himself Emperor. He was welcomed as ruler in Britain. Coins were issued in his name, as has been seen : some were found in this very boat-they are in a small case at the end of the same room. The jointemperors of Rome, Maximian and Diocletian, were unable to suppress him, and finally they recognised him for a time as sovereign in England. He was murdered in A.D. 293 by one of his officers, Allectus, one of whose coins was also found in the boat. Allectus was not a very capable person, and a general sent against him by the Roman emperors defeated and killed him in 296. Allectus' beaten army (mercenaries from Germany) fled to London, and plundered it: but they were overtaken and slaughtered by the victorious Roman general, Constantius Chlorus, to the joy of the Londoners. So London had a close connection with Carausius and his successor, and the Roman boat is a sign of 
how the city must have grown in importance since it resisted Cæsar three hundred and fifty years before. It is a relic of England's first admirala man great enough to set himself against the might of Rome.

Before returning to the Roman Room upstairs, there are one or two other Roman remains in this boat room to be looked at. There are the objects found in the boat itself-coins, horse-shoes, nails very like nails of to-day, a piece of a sandal, fragments of pottery. The boat itself was probably about sixty feet long by eighteen feet wide, when perfect : a picture on the wall shows what it looked like. The remains of another boat, a few stout ribs, are just inside the entrance door to this room, on the right. In a case of domestic implements just past these timbers are a few Roman objects-a rushlight holder, and an iron "strike a light," for use like a steel, to strike sparks, before matches were invented; and some discs or counters for use in a game. They are little things, easily overlooked : but once they gave pleasure to living men, who had no thought that their whole social order must pass away like themselves, and be no more seen.

Now to consider some of the individual objects in the Roman Room itself. Think what a gap, not only in years, but in the condition of London, lies between the Brentford palisade and the fleet of Carausius. It was Celtic when it fought Julius Cæsar: it was Roman when Carausius claimed a share in the power of Cæsar's successors. This room shows the difference. In the case of pottery 
over the fireplace, besides the Samian ware, there is some New Forest ware: dark, well-moulded pots with a very beautiful spiral design. It is better than the early Celtic pottery: it is finished work of which any potter might be proud. The New Forest was then the "Five Towns" of Englanda chief centre of pottery-making: under Rome in Southern England there was peace and law, to let quiet industries thrive. There is a little earthenware lamp-a flattish hollow saucer, with a hole in the middle of the top surface, through which a wick was thrust into the oil beneath. In the case in the middle is an example of what perfection the Roman civilisation of London could achieve in the making of lamps : it is a splendid work in bronze, graceful and finished in every detail. The difference between it and the earthenware one is not less than there is between a huge gilt candelabra, fitted with electric light, like those in the Cost ume Gallery at Lancaster House, and the ugly little straight brass gas-pipes of a poor London tenement house. It is the difference between the barest necessity and the adornment of life.

Round the room are various other objects which emphasize what has already been said as to the Romanisation of London: three more wine jars in fine preservation at the end of the room: a piece of pavement showing an interesting green monster of unknown breed: a cast of a group of goddesses (Deæ Matres) found in Crutched Friars -another branch of Roman religion: and, in a glass case in the further corner of the room, a little 
stone tombstone that speaks to us intimately across the centuries. The inscription is in GreekGreek to Rome was as French to us, " only more so": it was the language of fashionable culture. It runs, "Dexios, son of Diotimus, excellent, farewell" (Distimus in the label seems to be a misprint). It may commemorate a child: Dexios and Diotimus are alike lost from the annals of time : in any case, someone loved Dexios, and thought well of him, and was grieved at his death: and if we win no worse epitaph than that, it will not matter if not so much as our name is told to people centuries later.

In this case, too, are the remains of a flute, dumb for a thousand years and more; some slender pins ; and the beautiful little glass bottle: things that mattered once to people we can never know.

A label on the left-hand wall has been passed over for the moment : it will suit better the last exhibit in the room to be dealt with. The central cases may be mentioned here : they contain (besides the lamp already referred to) more pottery, some of it very good, and a few other objects, the most striking of which is perhaps a little weight shaped, and very well shaped, in the form of a head. There is also a " cinerary" urn. The Romans as a rule practised cremation (as did the later Celts: the prehistoric room contains Celtic cinerary urns). The ashes of the dead were put into urns like this : there are some in this specimen.

Under the central cases from the door are stone mortars for crushing wheat. That is perhaps the 
oldest business in the world. Neolithic man used exactly the same kind of implement : it was only superseded when windmills came into use in the Middle Ages (perhaps about the thirteenth century): and now windmills are dying out, and the simplest and most necessary of crafts has taken another step in its long, slow life. Britain in Roman days was a great corn-growing country : to-day we must live on bread from regions no Cæsar ever knew.

But it is at the case nearest the window, opposite the door, that we get nearest to the everyday life of Roman London. It is filled with objects showing the high state of civilisation in domestic life. (Remember that metal, when corroded by long years of burial in the earth, loses all its delicate finish and polish, so that these rough-seeming things were once smooth and bright " as a new pin.") On the top shelf are sandals, one a child's. The lacing is very complicated-it belongs to the end of a civilisation, not the beginning (see illustration, p. 57). In later rooms, just the same thing will be seen in the shoes of other periods: they were simple at first, and afterwards intricately wrought. Probably this complicated sandal had not to be fully unlaced before being put on: it was simply a net-work into which the foot could be easily thrust. It was netted, not solid-partly because the Roman pattern came from Italy, where the climate makes the open work more comfortable. The English slipper-like shoes of later periods, when the Roman rule and fashions were forgotten, were solid, to suit the wetter, colder English weather. 
Other finely finished objects in this case are the spoons and pins, some of them with very delicate carved patterns. Perhaps the most beautifully made thing of all is what is called a bronze altar : it is like a doll's house table of to-day (it may possibly have been a toy), and the workmanship is perfect. Look also at a bronze balance, for weighing light objects : it is very simple, but it is also very perfect for its purpose. There is another balance or "steelyard" upstairs which will be mentioned later.

The horseshoes in this case are exactly like horseshoes of to-day. So are the nails and tools at the window-end of the case. In things like these, meant for solid use rather than for ornament, there is no great change to be made when once the principle has been mastered : the workmanship may grow better and may be made more easy by new methods, but there is little else to alter. Roman civilisation had been in existence long enough, when it reached London, to have perfected even the workmanship, though of course the methods and machinery of eighteen hundred years later allow of greater ease of production to-day.

Lastly, beyond this case, on the wall, is a picture of Roman London, as it probably was; and here look again at the tablet on the other wall which has been passed over. It says that in the time of Boadicea (Boudicca is the form of the name given by Roman historians) London was perhaps surrounded by a stockade. Boadicea died in A.D. 59 . London Wall itself, an immensely strong work of rubble, brick, tiles, and mortar, was itself built a 
good deal later, perhaps nearly three centuries later. It ran, as the picture shows, right round the city, with gates at the main roads, and bastions or round towers at intervals. Many fragments of it are still standing to-day: one is visible just off Cripplegate, and under the General Post Office yard, between Newgate Street and St. Bartholomew's Hospital, there is a whole bastion, in wonderful preservation : the mail vans roll over its head. There is a picture of it on the right hand of the door. A city so stoutly walled must have been important.

What is known from other sources than the remains dug up shows how London grew till it was like the London of this picture. It was, as has been said, in a position of natural importance even before the Romans. In the period between Casar's invasion and the real conquest of Britain by Rome nearly a century later (by Aulus Plautius, A.D. 43). Roman civilisation and trade generally must have spread to London markedly, for though Camulodunum (Colchester) was perhaps the chief town of the south-east, there was probably, by A.D. 43 , a bridge at London; and Plautius fought a battle there. Bridges, in early days, meant towns to build and hold them. A little later, in A.D. 60, came the rising of Boadicea. The Romans from Camulodunum fled to London, and when the Roman general, Suetonius Paulinus, reached the city with his troops, he had to decide that for the moment he must abandon it: it can hardly have been strongly enough fortified for defence. Boadicea sacked it. 
It must have been worth sacking, even though it was not officially incorporated as a borough, so to speak : the first written reference to it in history, by the Roman historian Tacitus, says that it was "a town which, though not honoured with the title of a Colony, was very celebrated for the number of its inhabitants and the abundance of its resources."

Soon after that period, probably, the great Roman roads of England were made; and London was a chief junction of them. Watling Street, the road from Europe, there met other roads, and the famous London Stone, in Cannon Street (of which there is a photograph in the basement) was perhaps a central milestone of London. ${ }^{1}$

So from A.D. 60 onwards London, the old Celtic town, had a bridge, some sort of defensive wall, roads, and a settled and wealthy trading community. From that date until the outbreak by the defeated troops of Allectus (see p. 22) it enjoyed peace : and in peace there grew up that comfort, and that interest in the comfortable arts of living, that this room largely represents. The city had its religions. It had its bishops, for it was probably one of the earliest towns of Western Europe to harbour the Christian faith: and Restitutus, Bishop of London, was present at the important European Council of Arles in A.D. 3I4. A little later one Augulus, also a bishop, was martyred in London: in the turbulent times in which the

1 "Watling Street," near St. Paul's, is not the real Roman Watling Street. The name is a corruption of Atheling Street. 
Roman Empire was broken up, even Christianity sometimes suffered adversity. London coins were stamped with Christian emblems before those of many French towns : for Roman London was so prosperous that it had its own mint. It was perhaps most prosperous of all under the Emperor Constantine the Great, who made Christianity the established religion of the Empire. So important, in fact, did London become that it was given the honourable title of Colonia Augusta, which it bore from about A.D. 340 to 4 IO. But that period almost belongs to the next rooms to be visited, the rooms which show how London lost, for a time, its position of pride and security.

So the Roman Room has added a long chapter to the story of London : the chapter in which London first grew great-in which, perhaps, as Sir Laurence Gomme points out, it began to be aware of its own greatness, and proud of being London. And London was London, we have seen, for precisely the same cause as made it the home of palæolithic man: because it is on a great river. A river meant and still means traffic and intercourse with other people : all the towns which have for any long period stood high in the history of the world have been either upon a river or at a natural harbour.

The chief place in Roman London was almost certainly the temple and citadel on the site of Leadenhall Market. The city stretched from the Tower to Blackfriars Bridge, along the Thames, 
with a settlement across the water in Southwark, at the other end of London Bridge : the northern boundary ran from Liverpool Street Station, roughly, to Aldersgate Street Station (the Barbican was a tower in the wall near here, built later). 


\section{CHAPTER III}

THE SAXON AND NORMAN CORRIDOR

IT has been seen, in the two first rooms of the Museum, how long it took to build up a civilisation in London, and yet how fully that civilisation was developed. When the Roman Empire fell, history, in a way, repeated itself. Just as the Stone Age men had been superseded by the Bronze Age Celts, and just as the Celts had in turn been superseded by the Romans who used iron and steel, so the mixed race thus produced in England was to be overwhelmed by new invaders with utterly different customs and weapons. They were the people whom we call collectively, for convenience, the Saxons. In London the division of them known as the East Saxons (the name remains in Essex) were to prevail : the Middle Saxons (of Middlesex) were apparently only a part of the whole East Saxons.

The Saxon and Norman Corridor leads out of the Stone Age Room, on the right hand, opposite the entrance to the Roman Room. It is a passage (part of a larger room) looking out upon the green garden of Lancaster House. It does not contain very much at present, nor is it likely that it will 
ever contain so many objects as other periods furnish ; and that in itself tells us a great deal. If a particular period has not left many remains below the surface to be dug up by later generations, one of two things must have happened: either what was left was very perishable or else there was not much to be left. So far as we know, Saxon utensils were strong enough: probably, therefore, there was not much to be left. Why?

Any history of England gives the answer. A notice near the entrance to this corridor hints at it : it says that when England was finally abandoned by the Roman Empire (not entirely through Rome's fault, by any means), London was left desolate at the approach of Saxon invaders. It is not quite certain that that was the case; but at any rate London, even then the richest city in England, must have been in terror of these fierce pagan pirates, who, about A.D. 420, began to cross the North Sea and the English Channel not merely as casual raiders, but as organised invading armies, bent on conquest and on settlement. But, apart from London, England itself was no less troubled. From 420 to I066 there were hardly thirty years (one generation) of consecutive peace anywhere in the country. First the Saxons fought with the Romanised Britons : then they fought among themselves ; then they fought against the Danes: and last of all they fought against the Normans.

Now London, as its river presupposes, is by nature a trading city, and it was always inhabited by traders. Tacitus, already quoted, spoke of its 
commerce, and almost all the relics in the Roman Room are relics of peaceful life, not of war. But almost all the Saxon relics are relics of war: that is to say, Saxon London must have been unable to grow so quickly as it did later, because it had to fight for its existence, and could not follow, without interruption, its natural life of trade: and therefore there is not much to show of the life of that period-it was too uncomfortable for domestic ease. The Saxons, in fact, were not a trading nation. They were first of all fighters; though, when they established themselves fully, they were also, in a sense, politicians-they had strong and powerful institutions, which indeed were of great service to London.

The first wall case (on the right hand) shows the Saxon weapon-the saex, or scramasax, a hand knife. It is just the sort of weapon to terrify hand-to-hand fighters, to say nothing of peaceful citizens. The size of a sword, it should be remembered, is not necessarily its chief virtue : while a man is swinging a great two-handed weapon, his enemy with a scramasax may have wounded him to death. Those weapons, then, tell of savagery and battle coming very close to a peaceful, prosperous city.

The exact steps by which Roman-British London became a great town of Saxon England are not quite clear, nor does the London Museum contain objects which suggest the change in any striking way : except perhaps a bell " of Celtic type," found in the Thames at Mortlake, and ascribed to the 
eighth century after Christ. But before that date many things had happened. When Hengist defeated the Britons at Crayford in 457 they fled to London: London was a considerable city then, clearly. It was an important city in 898 , when Alfred the Great "restored" it (perhaps fortified it more strongly, or repaired it after the Danish raidsthe Danes plundered it in 85I). Between those two dates, 457 and $85 \mathrm{I}$, little is known, except the very striking thing that in 604 a Bishop of London was consecrated by St. Augustine, soon after Southeastern England in general had become Christian again, and that in 6ro the first cathedral of St. Paul's was built by Ethelbert. A little later, in 6r6, the Londoners turned out their bishop-so that they were strong enough then to be independent, if wrong-headed. They were strong enough, in fact, to reject for a time the Christian belief held by the powerful kingdom of Kent close at hand.

The one object in this first case in the Saxon corridor which suggests a comment upon this patchwork history, as has been said, is the "Celtic" bell. If the date and the workmanship are correctly given, it implies that in at least one striking instance the Celtic spirit, the racial genius of England that was older even than the Roman Conquest, still survived. The Roman Conquest, it should be remembered, was quite different from the Saxon Conquest : it was not the blotting out of a nation, and the incoming of a whole new race: it was the taking over of the government by an outside race, only a small portion of whose people actually settled in the 
country. In this it resembled the Norman Conquest more nearly than the Saxon; and nothing is more likely (more certain, indeed, in many respects) than that the conquered Celts kept much of their old spirit and nationality under their new governors, just as the conquered Saxons eventually grew strong again under the governing Normans. The bell is a little sign tending to prove that fact. Many historians, indeed, believe that London, with its prosperous Roman-British or half-Celtic population, never became really Saxon, and was never really conquered: that the Saxons stayed outside its walls, at the places with Saxon names, like Chelsea (Chelchith), Rotherhithe and Lambeth (Lambhithe): and that they accepted London as an independent fact-they tolerated it, and let it live, so that London alone in England kept its ancient British individuality. This view may not be proved beyond dispute: but there is more evidence for it than for any other explanation of London's continued existence during those centuries of war.

However, that is not a matter which the London Museum illustrates in detail, though it is a chapter in London's story which the Celtic bell helps to suggest.

Not less full of meaning is the reproduction of the famous "Alfred's Jewel "- $\mathrm{a}$ beautiful little pendant of gold, the original of which is in the Ashmolean museum at Oxford. "Alfred made me," is the inscription on it : and the jewel was found in the marshes of Athelney in Somerset. That is to say, Alfred had for his.kingdom a country which 
could produce work so fine as this : and yet, though his capital was at Winchester, he was in hiding in Athelney. The next great change in the history of England and of London had come. The Danes, burning, murdering, plundering, as the Saxons had before them, were all over southern and eastern England, and the great King of Wessex was a refugee in the farthest corner of his dominions. Yet Alfred had a coinage, minted in London (there are specimens in this case); and the Saxons, as their weapons show, and as we know from history, were a sturdy race; and they eventually beat off the invaders. But it was not until London had been many times attacked, and until a great Danish king, Canute, had ruled both in London and in England that London stood out again triumphantly as the chief city of Britain.

The Alfred Jewel, apart from its historical interest, is a well-known example of a particular branch of handicraft. It is ornamented by cloisonné, or cellenamel-enamel in little nests or cells of very thin metal. That is a very ancient art : it came to Western Europe, probably from the East, by way of Constantinople and the "barbarian" peoples who broke up the empire of Rome. So a little relic like this joins England, a lonely island fighting for its bare existence, to centuries of old civilisations and races of whom no Englishman of Alfred's day had ever heard.

There is another object close to this case which shows how real was the Danish invasion. It is a cast of a Danish monumental stone (the original, 
found in St. Paul's Churchyard, is in the Guildhall Museum). The inscription on it reads: "Konal and Tuki caused this stone to be made." The Danes had a camp at Fulham; and they settled in Aldwych: this stone means a long settlement. Turn to the next case : here is a tremendous Danish sword found in the Thames at Wandsworth : and here also is a grimmer relic-a drinking-cup made out of the skull of a fallen enemy. And this is what the Anglo-Saxon Chronicle, the chief record of those terrible days, says of the worst period of the invasion, A.D. IoI8: "In this year tribute [to the Danes] was paid over all England: it was in all $f 72,000$, exclusive of what the townsmen of London paid, which was fIo,500 pounds." All England was subject to the fierce pirates; even London, which in many battles before IoI8 had resisted them successfully; and London, in spite of sieges and the interruption of its trade, could afford to pay oneeighth of the whole tribute of England.

Perhaps that history seems a little far away from the few weapons shown in these cases. Yet it is really very near them. That skull is the skull of a London man who fought in those days for all that was precious to him : by men like him the spirit of London was kept alive, and the London of after years made possible. This very case in which the drinking-cup lies shows how quickly the life of the great city could revive, for it contains relics also of unwarlike days.

But before looking at them something must be said of London Bridge, about which there are many 
details to be seen later. It was highly important in Saxon times, for, like very many other things of importance in the history of London, it goes back into the most distant past. We have seen that it existed in some form in the earliest Roman times. The Thames led the Saxons into the very heart of England, and when the Saxons had conquered England, it led the next invaders, the Danes. But London by then knew its strength. The Londoners fortified the wooden bridge strongly, and when Canute besieged the city in IoI6 he had to cut a trench south of the Bridge through Southwark, to get his ships above the Bridge, and so keep up the siege strictly. The river, in fact, so long as London Bridge was not broken down, was a strong fourth wall for the city, as well as the channel up which trade and wealth flowed into it in times of peace.

The Bridge is mentioned here to show the continuity of the main element in London's life. The London Museum has drawn many of its treasures from the bed of the Thames. In later rooms are evidences of the Bridge's history, which, so far as this Saxon Corridor is concerned, lies only in books, not in the objects exhibited.

In the same case with the skull-cup are the less dreadful things, which show that some time at least in those centuries of war men loved peace and lived in quiet happiness. There is a little toy axe which never went into battle for harm : it may be a toy, or an ornament, or a charm. There are counters or pieces of some unknown game; a 
little forlorn bead: a beautifully finished bone comb and its neat case, from Threadneedle Street. Someone once was proud of these possessions. Where now the Bank of England guards the gold of the world's capital, some nameless, forgotten Saxon or Dane once made himself a fine figure of a man, or some woman eagerly awaited the return of her husband from his battle in her behalf.

In this case also is a chapter in the history of warfare-an explanation of how a particular kind of sword handle, with a "lobated pommel," arose. A relic-a piece of some sacred thing, or something blessed by a holy man-was bound on top of the hilt ; it gave the hilt a kind of knobbed appearance, and presently hilts were made all in one piece of this shape, the original purpose of the "knob" or lobe being forgotten or neglected. Another point to remember is that these relics had a religious origin : men therefore fought in the name of God, or trusting in His aid. The Roman-Britons, mainly Christians, had hated the pagan Saxon; the Saxon, converted to Christianity, hated no less the pagan Dane.

This little piece of history deserves more than passing notice. It is an excellent instance of the way in which observation and deduction reveal the mind of the past generations, and give life to dead things. It is the belief that everything has a human meaning, and the endeavour to find out the meaning, which makes a museum a real thing. It is a curious fact that some of the most important discoveries in prehistoric history arose from the 
careful study of weapons in this way. General Pitt-Rivers, who perhaps did more than any other man for the study of the Stone Age, had a great collection of modern and fairly modern arms, and was also in charge (and virtually founder) of the Hythe Musketry School. He noticed that even in such new weapons as muskets many details in a modern gun seemed to have no purpose, until he discovered the stages by which those details had assumed their final shape, and saw what the original purpose was. He applied this idea to his study of stone weapons, and so was able to trace, more surely than ever before, the way in which prehistoric man had progressed. So in these lobated hilts we see how a device formed by a religious hope ended in a mere conventional knob, and we can work backward from this meaningless knob to the very minds of the men who first used such swords.

The game counters are said to be of the eleventh century; and so we reach the Normans, the last race to overflow into England by way of war (racemovements are still going on-at present, for example, from Eastern and Central Europe to America -but they are no longer warlike, though in the long run they may have as lasting an effect as a war). The third case in this corridor contains Norman or " early mediæval" objects. They have a full meaning. The spurs, for example, are made more varied than in earlier times: they are the spurs of men who had seen other nations, and had not been shut off from Europe in an island struggle. There is a bronze vessel of much more individual and 
ambitious shape than anything but the best RomanBritish vessels in earlier days. There is a bronze Christ, with traces of Limoges enamel-a moderate but well-preserved example of the rich and beautiful work which was already being done on the Continent for religious purposes. There is (on the wall close by) a facsimile of a reliquary, or case for relics: the original is in the Guildhall Museum. All these things show a great advance in civilisation : it is no longer barbaric, no longer dominated by the needs of war: the Christian religion is reasserting its hold on everyday life. And there are also in this case various pieces of pottery.

Those are two subjects (very dissimilar, and very unlike, of course, in real importance) which are of great value to those who study the history of London. Religion, apart from whatever men believed personally at any time, has had an immense influence in shaping the very stones of London all through the centuries; while pottery reflects the history of private life.

The Christian religion in London-and London, as has been said, was one of the earliest and most steadfast of Christian towns in Western Europe-has had two centres, St. Paul's Cathedral and Westminster Abbey. ${ }^{1}$ St. Paul's was first founded, it is said, by Ethelbert, in A.D. 6ro-6I4. But it was to the Normans (a race of great builders) that the fame of St. Paul's was chiefly due: the old cathedral was burnt down in 1087: the cathedral

1 For their history in detail, see the volume in this series dealing with them, by Jocelyn Perkins and J. S. Bumpus. 
which lasted till the Great Fire of London, five and a half centuries later, was then begun. Westminster Abbey has an even more ancient history, but its greatness really begins with Edward the Confessor. The first Christian king of Essex, Sebert, is said to be buried on its site, where he had in $6 \mathrm{I} 6$ built a like Christian church. Saxon kings later made grants of land to the church there. Edward, however, began, in I050, the far more glorious building in the Norman style which stood till the thirteenth century, when Henry III set up the Abbey which we see to-day, enlarged and made more beautiful in almost every century since his day.

Under the Normans then, there was such faith and such prosperity, at any rate among the richer people, that these great houses of God could be built with good hope of their endurance. It was, however, full of importance to Londoners that under the Normans also the Tower of London was begunthe only one of these three splendid buildings which remains almost in its original form. The Keep, or White Tower, was begun in 1078 at the request of the Conqueror, by Gundulf, Bishop of Rochester: it was intended to overawe the men of London. Great buildings in the Middle Ages were very often the sign of a rich and even tyrannical nobility.

There is in the Basement a model of the Tower of London which may be mentioned here. It is in the room opening out of the Roman Boat Room. It shows the Tower practically as it is to-day-a collection of buildings of all periods, the story of 
which would involve two other stories-that of architecture and that of England. The keep is the central square "tower"-the Tower. The later Norman kings added the walls.

Pottery also is a subject which needs a special study. The points to be remembered here are that native pottery, in England, was as a rule very, simple ware; and ornamental pottery - " china" or porcelain-was produced, comparatively late in history, in imitation of foreign fashions. The beautiful wares of later times, therefore, belong to a period when England and London could turn their attention to outside affairs, and could cater for luxurious tastes, as well as for the necessities of everyday life. In Norman times, only the necessities were supplied.

Pottery, pure and simple, is a very obvious business. It consists of moulding wet clay into any desired shape, and letting it dry. By drying it in a great heat, strength is obtained. Glaze is added in the same way-a metallic or saline material is put on wet, in the form of a thin paste called slip, and cooked at a great heat till it is dried. Up to about A.D. I60o, the glaze in England was of the plainest kind, and the Saxons apparently used none : they simply made clay pots, like the Celts before them. A green glaze begins to appear on vessels made about the thirteenth century-just after the end of the period covered by this Saxon-Norman Corridor, in fact. The Saxons and Normans, then, to judge by their pottery, were not greatly concerned with making the smaller details of life 
beautiful. They turned their attention to larger matters.

So we have reached the foundations of the London whose vestiges have lingered into our own day in active use-the glorious churches and the beginnings of a continuous domestic life. There were to be no more invasions, no more large changes in the rulers or inhabitants of London : and every son was to succeed his father as king succeeded king, and without even the change of dynasty or race that sometimes came into the monarchy. But if the new London was that which continued right down to our own time, it yet had also, even then, a past which it has never since given up. It did not become Norman London: it remained London. Every Londoner ought to know the simple charter given to his ancestors by William the Conqueror:

"William the King salutes friendly William the Bishop, and Godfrey the Portreeve, and all the burgesses within London, French and English. And I declare that I grant you to be all law-worthy as you were in the days of King Edward [the Confessor]; and I grant that every child shall be his father's heir, after his father's days; and I will not suffer any person to do you wrong. God keep you."

That is a unique charter-a recognition by a great conqueror of the greatness of a city which it was in his power to conquer, but which he did not conquer. William made this special treaty with London: he did not force it to make terms. He allowed London 
of the infinite past to keep its old privileges and its old character; and his successors, though some of them tried to take away the powers of the city, in the end acknowledged its unique and splendid position. Londoners could almost make and unmake kings. They had elected Edmund Ironside King of England in IO2I, when all the rest of England chose Canute. They called in the Empress Matilda against Stephen in II4I, and then drove her out when she sought to abuse their liberties. They rebelled in IIgI against William Longchamps (the Chancellor left in charge of England when Richard Cœur de Lion went crusading), and set up their own "commune "-a picture on the wall shows the expulsion of Longchamps. Truly, as an old historian said, "it is a good city indeed when it has a good master" ; but it would have no master whom it distrusted.

The peaceful charter, however, did not prevent an unfortunate occurrence at William's coronation, when the citizens, acclaiming the king according to their ancient custom, were thought to be rioting and rebelling, and were attacked by the Norman guards. A picture of this incident is shown on the screen wall.

Except for the Danish settlement at Aldwych, the memory of which still lives in the church of St. Clement Danes, London in Saxon times must have been in extent almost the same as Roman London. Under Edward the Confessor and the Normans, 
Westminster began to have a steadily increasing importance : the Court lay inside the city. Henry I, however, gave, or rather leased in a perpetuity which has never really been broken, Middlesex to London as a " farm." 


\section{CHAPTER IV}

\section{THE MEDIAVAL ROOM}

THE Saxon-Norman Gallery leads into the Mediæval Room, which covers the period, roughly, from A.D. I 200 to I500-from John to Henry VII. At the very entrance, the two great sides of the life of the period are indicated. Immediately opposite the door is a case of weapons, and on the wall on the right hand is one of the first books printed in London or in England-The Chronicle of England, printed and published by Wynkyn de Worde in I497.

To take the swords, and the warlike events, and the affairs of state first. This was the period when great kings went warring with English troops in Europe, when the English archer overthrew the knights of the age of chivalry; when warfare, before gunpowder changed its whole aspect, attained the highest development that sword and spear and steel armour could reach. Look at the arms in the case in front of the entrance. They are not the handy murderous weapons of pirates, who wished to wound or kill with all speed, and be gone with their plunder. They are the more solid and cumbrous implements of orderly battle-of men fighting under discipline or under a code. The 


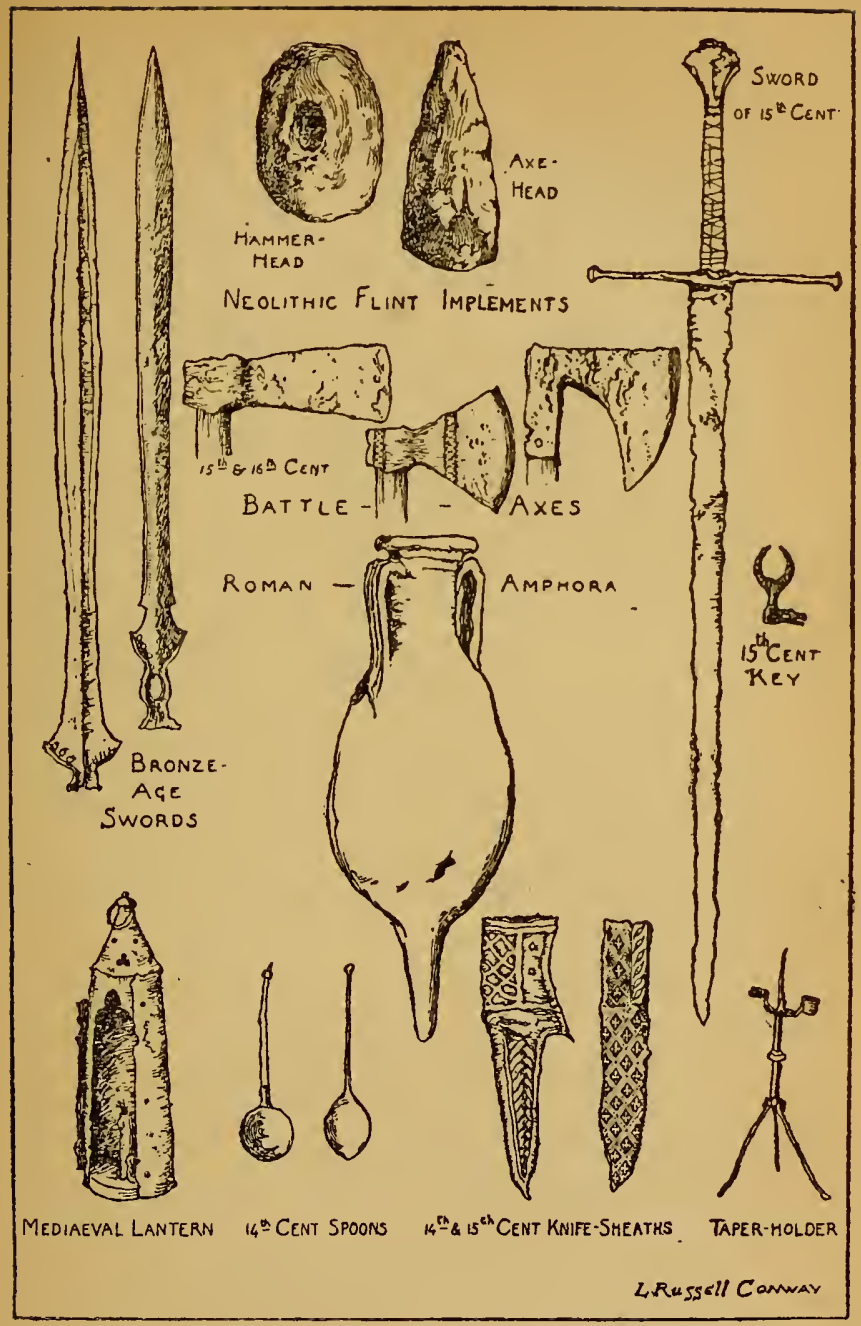

Weapons of the Early Periods, and other Objects 

huge " bastard sword," which is exactly like one on a tomb of $I 430$, is, so to speak, a full-dress weapon -a thing to be used in a set combat, where the enemy was armed equally well. The great battleaxes (and the pole-axes and mace in other cases in this room) were meant to bite through stout armour, plate or chain mail like that shown in a case on the right hand of the door (this piece of mail was, perhaps, on view at Don Saltero's coffee-house in Chelsea four hundred years later: the coffee-houses will be reached further on in the Museum).

On the back slope of this first case are many fine daggers. In the first case against the wall opposite the door are some excellently worked leather sheaths for knives or daggers. In the next case is an archer's "salade" or round helmet. In I347 the helmetmakers of London obtained a regulation of their trade to ensure that strangers or newcomers should not work at it unless they were proved to be good workmen : good workmanship, and the system of apprenticeship and orderliness which it involved, were considered to be essential. The great City Companies of to-day probably originated in combinations of this kind to maintain the standard of the trade : though this is not known with certainty.

In the central case are some pieces of plate armour, some spurs of terrible length, arrow heads, chapes (the tips of scabbards), gipciers and their mounts (a gipcier or gipsire was a pouch or wallet, of various shapes) ; all of which illustrate in various ways the warfare of the period. It is often thought, perhaps, that a knight in full armour was a splendid sight. 
So he was; and he was doubtless a very formidable enemy too. But it must not be forgotten that armour had its drawbacks. It is very unlikely that the pictures of knights dashing at full speed into battle, with fluttering pennon, the war-horse galloping wildly, are true. The war-horse was much more like our cart-horse than our thoroughbred, and few horses could really gallop with several stone of steel on their backs in addition to a man; a fully-armed man as late as $1560-$ when armour was falling into disuse-weighed twenty-five stone. If the knight was unhorsed, he could move but clumsily : if he was thrown down, he might even be unable to rise. He needed a squire for the simplest adjustment of his armour. That is why the English archer, leather-jerkined, fighting at a distance, was so terrible to mounted men ; they could not reach him, and his marksmanship found out the joints in their armour before ever their heavy swords could cut him down. The knights thought the archer unfair : later on the archer with the longbow thought the crossbowman unfair; and archers of all kinds thought gunpowder unfair.

The archer had a significance outside his importance in war. He was not nobly born, but he was just as good a man in battle as the noble. The people of England-the Briton, the Saxon, and the humbler Norman, all those races who were mixed in the Englishman-were proving that they had a place, and a very important place, in making the history of their country. In the history of London this period proved the same thing: the rebellions 
of Wat Tyler and Jack Cade fell within it. There is a curious link with the past in a famous action of Cade's. Coming to London Stone, he struck it with his sword, saying, "Now am I lord of this city." London Stone, by a very strong tradition, is said to be Roman, or even pre-Roman. It has been supposed (as has already been mentioned) to be either a central mile-stone, from which distances were measured, or the mark where the citizens met in public assembly. Whatever it was, Londoners have always held it important. It lies to-day behind a grating in the wall of St. Swithin's Church, Cannon Street : in the basement of the Museum there is a good photograph of it. The point here is that this symbolic act showed how necessary Cade thought it to be that he should be Lord of London. Neither he nor Wat Tyler was a Londoner: they stood for the common people of England, resisting what they thought to be unjust and oppressive taxes; and London was the place to obtain redress. As a matter of fact, the more substantial Londoners helped to put down the risings : the story of how Walworth, the Lord Mayor, killed Tyler is well known.

London, in fact, was now beyond all doubt the chief city of England-the freest, the wealthiest, the proudest, ready to oppose all, even kings, who dared to infringe its liberties or threaten its prosperity. Kings enlarged and strengthened the Tower of London, from which at will they could attack the City ; but the citizens would not admit that the Tower had any lawful right to control them. They 
would not even admit that the King could enter the City without leave; and the old ceremony by which to-day the sovereign, on State occasions, is met at Temple Bar by the Lord Mayor and formally given the keys of the City, is a survival (or revival) of that mediæval independence.

Above all, the King, from Norman days onwards, has been crowned in London, unless exceptional circumstances prevented. In this Mediæval Room is a reminder of a very early coronation. In a small case near the entrance to the Jewellery Room (opposite the entrance from the Saxon Corridor) is a fragment of Edward III's coronation robe. Edward was crowned at Westminster in 1327. Only the year before the citizens had revolted against his predecessor, Edward II, though five years earlier, in I32I, they had received from him a new charter, defining their constitution. They were still "good citizens when they had a good master."

It was Edward III who realised the importance of the archer. In 1365 , he wrote specially to the Sheriffs of London about training in archery, by which "honour and profit have accrued to our whole realm." He bade the sheriffs see that the young men in their leisure practised diligently with " bows and arrows, or pellets, or bolts," instead of playing football or bandy, cockfighting, or " such other like vain plays, which have no profit in them." So there is a very close connection between the archer's salade and that little piece of a great king's vestment.

But there were victories of peace no less renowned 
than Creçy and Agincourt in this period, whereof the Mediæval Room gives abundant proof. It is impossible to realise to-day what the world was like without print. By their simple inventions, Caxton and Wynkyn de Worde created a world in which men could exchange ideas without ever meeting face to face, in which news could be made known without word of mouth, in which learning and literature could be spread abroad without schools. They more than doubled the contents of men's minds.

It is a wonderful coincidence that very little before the invention of printing lived one of the greatest of English writers, whose fame, perhaps, might have been less, or at any rate far more slowly acquired, but for Caxton. Chaucer was born in London, lived in London most of his life, and wrote most of his poems in London; and London first printed his works among the earliest products of the printing press. There are many things here to remind us of him, if none directly connected with himself. In the first case against the wall opposite the entrance door are some flesh-hooks. They are of exactly the same type as is borne by the Cook in the famous illuminated Ellesmere manuscript of Chaucer's Canterbury Tales. Those hooks were used by rough, coarse, jolly, even drunken cooks like Chaucer's, who

" knew well a draught of London ale,

Could roast, and seethe, and broil, and fry, And for blancmange, he made it with the best."

In the same case is an ampulla-a little flask: just such flasks as these did the pilgrims carry 
away from Canterbury when their pilgrimage was ended-flasks said to contain a minute drop of water tinged with the blood of the martyred Thomas Becket.

In the next case on the same wall is a greenglazed costrel, or pilgrim's travelling flask. Against the right-hand wall is a pilgrim's staff. If it were not for the Canterbury Tales, we should hardly be able to realise what a pilgrimage was. We should learn from other writers that some pilgrims were noisy and riotous, making their errand but an excuse for a boisterous holiday: or that other pilgrims underwent great hardships in their pious zeal. But that great London poet, who was born in Thames Street, near Walbrook, and lived long in the Gate House at Aldgate, shows us the pilgrims as English folk like ourselves-gentle and rough, rude and courteous, hopeful, sad, affected, simple, rogues and honest men : our forefathers, and our flesh and blood, every one of them. There is hardly a word in the prologue to the Canterbury Tales which does not fit equally well the people of to-day. It was by men of like passions with ourselves that this staff and costrel were borne.

Till very recently a few of the old inns of London, like the Tabard (or Talbot, as it was mistakenly called later), where Chaucer's pilgrims first met together, were still standing. In the rich collection of London prints and photographs in the Basement of the Museum will be found pictures of some of them.

There are in the cases on the right hand of the entrance, on both sides of the room, other little 


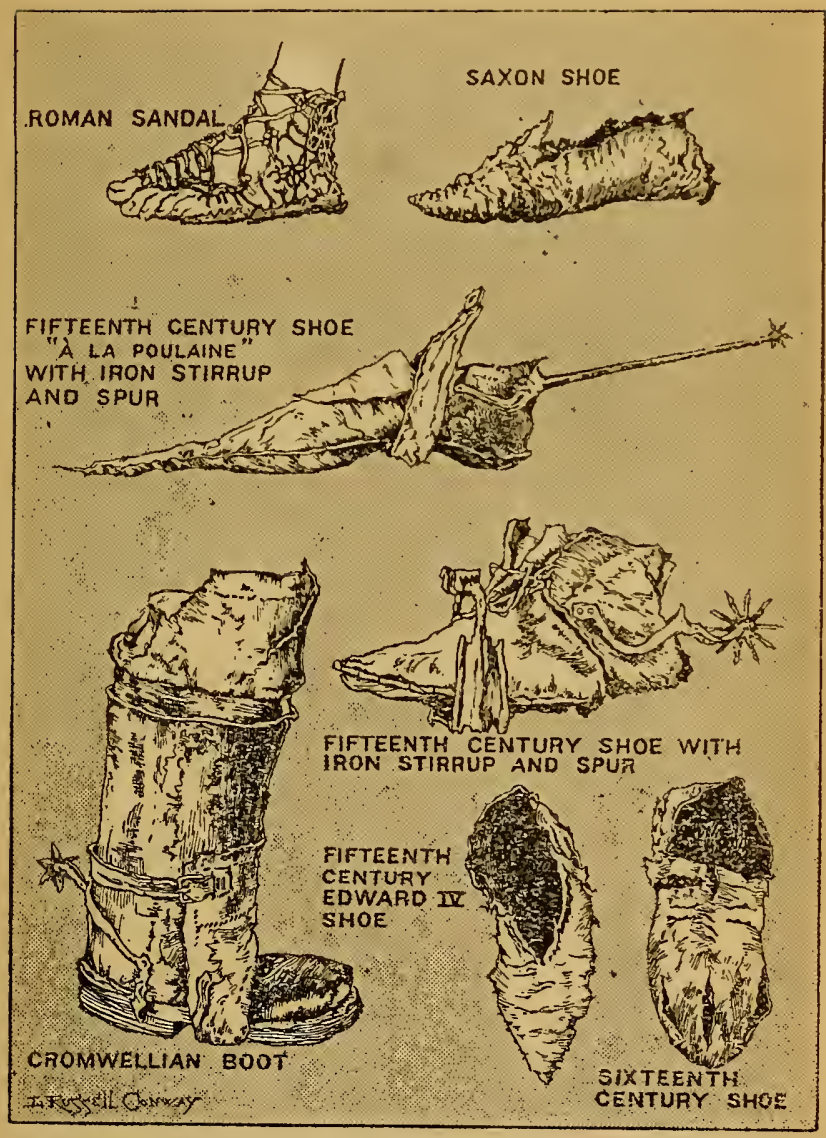

Fifteen Centuries of Shoes 

domestic objects which tell their simple story without comment: some mortuary and absolution crusses, placed upon the breast of the dead: some little ornamental discs and bosses, and a mould in which such things were cast : clogs to carry their wearers dry over the muddy London streets: shoes, some of them with the tremendous spurs already mentioned : a few keys and other pieces of metal work : a fine bronze ewer: and thrift-boxes, or moneyboxes, and other pottery. (The money-boxes were fairly safe receptacles : they could only be emptied by being broken). The pottery is important because it is glazed with green : it is in this respect a great advance on what has gone before, and shows that the makers were beginning to think a little of beauty as well as of use.

Last of all there are to be mentioned some architectural remains, and a picture, near the exit door, of London in the fifteenth century. On the righthand wall are some bosses from the Grey Friars Monastery, which stood where later Christ's Hospital, the famous "Blue Coat" School, was erected, and where now is the General Post Office (Christ's Hospital was removed to Horsham in I902). In the centre is a piece of carving from Crosby Hall, all that remains of which has now been restored and set up at Chelsea, near Battersea Bridge.

The first half-century of this period was one of great monastic activity. In I22I the Dominicans founded a house in Holborn (which then ran down to the Oldbourne or Holbourne River roughly at Holborn Viaduct, where Farringdon Street is now). 
Fifty years or so later the Dominicans moved to Baynard Castle (between the present Queen Victoria Street and Ludgate Hill-a tavern, the Baynard Castle, preserves the name of the castle which formerly guarded London Wall at that point). In I224, the Franciscans, the Grey Friars, built their monastery on the north side of Newgate Street, and in $\mathrm{I}_{24 \mathrm{I}}$ the White Friars, the Carmelites, settled south of Fleet Street. The names of Blackfriars and Whitefriars still remain: but of the great buildings and of the monks not much more is left than these bosses.

At the beginning of the period there had been two other notable pieces of building, which should be mentioned here, though they appear in this room only in the picture of fifteenth-century London. In I209 the new London Bridge was finished (sixty or seventy yards east of the present bridge). Formerly there had been only a wooden bridge: the new one was of stone, and it lasted till I83r. It was maintained in repair largely by the rents of the houses built upon it. There is in the Basement of the Museum a fine model of it as it was in I630. It must have appeared very much the same in the fifteenth century : perhaps even then the heads of the traitors were stuck up over the gate-house, as they are in the model. Stow tells some strange events in its history. Four years after it was built, there was a fire at either end, and the multitude of people on the Bridge at the time fell into a panic, so that about 3000 were drowned or burnt. In I282, "through a great frost and deep snow, five arches 
of the bridge were borne down and carried away." Later on we shall reach frost fairs upon the Thames, when the whole river was frozen over: such occurrences were largely due to the narrow and dangerous arches of London Bridge, which prevented the larger fragments of ice from the upper river escaping, and so locked the channels and allowed the river to freeze all over.

In 1395 there was a tournament on the Bridge, on St. George's Day : Lord Crawfurd of Scotland overthrew Lord Wells of England. Over the Bridge also, in I38I and I450, marched Wat Tyler and Jack Cade with their forces. The houses were from time to time burnt down and rebuilt up to the seventeenth century, when they gradually fell into disuse : the last of them was pulled down in 1757 . In the middle of the Bridge was a chapel dedicated to St. Thomas Becket.

Crosby Hall is, or rather was, an instance of the noble state maintained by the rich merchants of London: "was "- -because when, in I908, there was an opportunity of preserving the Hall intact on its original site off Bishopsgate, the rich men of London declined to subscribe enough money for the purpose, and it was pulled down, to be set up again in its present position in I9Io. From the thirteenth to the sixteenth centuries the merchants of London had a public spirit seldom equalled anywhere. They were wealthy enough to buy the royal plate of Henry III, when that spendthrift king was hard pressed for money : strong enough, as has been said, to revolt against Edward II : patriotic enough to imprison, 
in I4I5, one of their aldermen who refused to take office when elected. Of their stateliness a famous story is told.

The Mayor in $\mathrm{r}_{4} 64$ was asked to the banquet of the Sergeants of the Coif, ${ }^{1}$ but on arrival he found that the Earl of Worcester was given precedence of him. Now "within London the Mayor is next to the King, in all things." He therefore withdrew, and with him the aldermen, to whom he at once gave a rich feast. The' officers of the Sergeants' feast, however, feeling ashamed, sent him a present of "meat, bread, and wine, and divers subtleties." But when the bearer of this present saw the feast the Mayor was holding, he was himself ashamed, "for the present was not better than the service of meats before the Mayor."

That is a tale of official magnificence. Stow gives a long list of private benefactions to public causes. A large part of London was supplied with water by the gift of private citizens. In I246-7 Simon Fitzmary, Sheriff, built Bethlehem Hospital or "Bedlam" - then near where Liverpool Street Station now is : on the dissolution of the monasteries, in I547, it became a madhouse. Sir John Poultney, in I337, built three churches (his name is preserved

1 The Sergeants of the Coif were sergeants-at-law-counsel admitted to the Society of Sergeants-at-Law, and so named because of the coif, or headdress, which was part of their official robes. Serjeant's Inn, in Fleet Street, was their headquarters during the seventeenth and eighteenth centuries. It was pulled down at the end of that period, and the present houses built: but of those houses themselves the portion facing Fleet Street has just disappeared, to make way for the new offices of a great insurance company. 
in the church of St. Laurence Poultney), and gave much money to charity. In I378, John Philpot, formerly mayor, hired rooo soldiers to put down pirates, and two years later released from pawn, at his own expense, the arms of I000 English soldiers in Brittany. Thomas Falconer, mayor in I4I4, lent Henry VI I0,000 marks (about $£ 6600$ ), built the postern gate of Moorgate, and cleared the City ditches. Richard Whittington, three times mayor, built half the Guildhall library, repaired St. Bartholomew's Hospital, and built anew Newgate. John Wills, mayor in $\mathrm{r} 433$, paid for bringing water from Tyburn to Cheapside. John Colet, a citizen who became Dean of St. Paul's, founded St. Paul's school, and there are countless other rich benefactions. In fact, as an earlier chronicler says, "Above all other citizens everywhere, the citizens of London are regarded as conspicuous and noteworthy for handsomeness of manners and of dress, at table, and in way of speaking."

So in the Middle Ages, which is perhaps one of the most difficult periods of history for us to-day to imagine and realise, London was worthy of itself. It lived through war and peace with the same high spirit, a spirit based on a life then fifteen centuries old, and more, and issuing in a greatness of which the coming Tudor period was to be only the prelude.

Mediæval London saw the beginnings of great extensions outside the City walls. Almost all the religious houses were so situated. Southwark be- 
came definitely part of the City, and westwards the buildings must have stretched at least as far as the Temple (the home of the Knights Templars up to I3I3, and after that, as it still is to-day, the headquarters of the men of law). 


\section{CHAPTER V}

\section{THE JEWELLERY ROOM ${ }^{3}$}

THE Jewellery Room opens out of the Mediæval Room, and is at the western corner of the garden front of Lancaster House. It corresponds to the Roman Room at the eastern corner. In it are exhibited most of the jewellery and some of the finest pieces of plate in the Museum, together with some Nelson relics and kindred objects. For obvious reasons, it is both safer and more convenient to keep valuable articles of this kind all in one room, even if it interrupts for the moment the general chronological order of the Museum. For the sake of clearness and contrast a case of nineteenth century jewellery, shown upstairs in the long Gallery of Costumes, is treated in this chapter with the earlier objects which are in the Jewellery Room; and a few exhibits from the basement are mentioned here also.

Jewellery and plate, of course, reflect, even more closely than less valuable things, the mind and character of their original owners. They are not, strictly speaking, merely useful possessions : they

1 The author is greatly indebted, in this chapter, to the wonderfully full, clear, and concise Guide to the Medicval Room of the British Museum-a guide to a noble collection, and an encyclopædia in little. 
are made and bought to gratify the pleasure or the vanity of the possessor, who therefore cannot help showing, by his choice, what his private tastes and preferences are. They suggest also, in most cases, the state of society in which they were first produced: gold might be valuable in one place or during one period, silver at another : one generation might be more religious than another, and so incline more to ecclesiastical or sacred figures in its ornaments: another might be simply proud of wealth, and therefore anxious to make a great display of solid gold; and so on. On the other hand, there are really not very many different ways in which jewels can be used; rings, chains, bracelets, pendants, earrings, brooches, clasps, and pins-nearly all the possibilities are exhausted, in one way or another, in that list. Thus there is not a great deal of variety or progressive change in the history of jewellery. The changes are much more in the detailed workmanship than in the main purpose, or even in the general shape. It would be useless, therefore, to describe every object in this room in detail, because each visitor is capable of making his own criticism of it. It is better to select for comment those articles which are most typical or suggestive.

The first case on the left as the Jewellery Room is entered contains domestic (household) silver from I660 to I83I (Charles II to George IV). It is a fine but miscellaneous collection. Perhaps the best piece is the standing cup and cover, dated I640 (gold and silver ware bears marks which almost invariably 
fix the date exactly: each ycar has a letter to denote it, and other marks denote the reigning sovereign and the place of manufacture). It would be the possession of a wealthy household, and would be used either simply as a drinking-cup, or as a loving cup for drinking " good health " ceremonially. The ritual of drinking healths in this way is preserved in many old societies, like the Oxford and Cambridge Colleges, the City Companies, and elsewhere : or, if it is not " preserved," but rather revived or invented yearly, it at any rate commemorates the original idea of such a ceremony. The most usual form is for the person behind or at the unguarded side of the drinker to stand up as he drinks to a third person, as if to protect him from treacherous attack-for often a treaty or agreement was solemnised by drinking a pledge, and in fiercer ages treachery might seize this opportunity.

Cups of this shape (usually, as here, with a beautiful cover) have been in use for many centuries, though the oldest example known to be made in England is of the fifteenth century.

It will be noticed that practically all the gold and silver plate in the Museum is of the seventeenth century or later. Few museums in England or abroad have much that is earlier. The reason is obvious. Plate was easily melted down into plain metal which could be used for coinage. Wars and consequent taxes, civil wars and consequent sacrifices for the cause, did away with quantities of valuable possessions of this kind. At Oxford, for instance, nearly all the colleges melted down their 
rich stores of cups and flagons and tankards when King Charles needed money. Apart from that, old pieces were often melted and reshaped into new designs to suit individual fancies.

The same case contains forks with three prongs, dated $\mathrm{I}_{723}$ : in the right-hand corner case in this room are two-pronged forks. Forks earlier than the seventeenth century are very rare. One of the truest of threadbare sayings is that " fingers were made before forks." It implies a long-past chapter in the history of manners. Before forks were invented (if such a simple thing can be called an invention), fingers were forks. Mediæval literature is full of references to the need for wiping the fingers after eating. The Prioress in Chaucer's Canterbury Tales, for example, was

\section{" at meat well taught withal ;}

She let no morsel from her lips downfall, Nor wet her fingers in the sauces deep.

Well could she carry a morsel, and well keep, That never a drop would fall upon her breast."

It was a very important part of a squire's education to know how to bring his master, the knight, the washing basin at the right moment and in the polite way. In the third case (as one goes round the room from the left) is a fine example of a silver washingbowl of the time of Charles II. By that period, however, forks had come into fairly general use among the richer classes. Englishmen began to travel on the Continent with some frequency in and after Elizabeth's reign, and there they learnt the more dainty ways which were becoming fashionable 
abroad, especially in Italy. Even up to the end of the seventeenth century, however, guests usually brought their own forks to a feast : they were not quite the everyday equipment of a household. The twopronged forks were probably for fruit or sweetmeats. Four-pronged forks, such as are used to-day, are still later than the three-pronged examples here shown.

The snuffers in this case (dated $I 7 \mathrm{I} 7$ ), again, are also signs of an age of inconvenience long finished. It is hard to realise that only a hundred years ago almost all houses depended upon candles-and candles so clumsy that the wax or tallow melted away from the wick long before it was consumed, and so made snuffers necessary. But perhaps, as candlesticks and snuffers were usually given more graceful and delicate shapes than most modern gas or electric fittings have succeeded in producing, what we should regard as a disadvantage had very strong compensations. A house lit entirely by candles, in holders of beautiful design, tended by snuffers so gracious as these, must have had an air of peace and sedate harmony which might raise a feeling of envy in our noisier, more hurried life of to-day : and yet those snuffers may have kept the candles burning for many a wild gamble or drinking bout, for many a Vauxhall revel or St. James's rout no whit less gay and interminable than any festival of two hundred years later.

It is worth while here to mention certain objects shown in the Roman Boat Room in the basement. They are the corollary of these snuffers, or rather, 
the problem to which the snuffers are the corollary. The making of fire and light, as has been seen, was one of the earliest and most difficult lessons which primitive man had to learn : and yet the lesson, once learnt, never varied for thousands of years. You struck a flint, you obtained a spark, you had some very dry substance ready for the spark, and lo ! flame. In a case on the right of the door into the Roman Boat Room are flint and steel. They are, in forms differing very slightly, one of the oldest and most precious of man's possessions. Just as the Celt and Roman struck a light, so also did Londoners under the Georges and the Stuarts. There are matches here, too-strips or spikes of thin, dry wood, lightly coated with sulphur. The Romans used such matches. Englishmen used them till, roughly, Queen Victoria's accession. They did not "ignite only on the box": they were convenient additions to the supply of tinder-little torches, in fact; small models or prototypes of the torch shown in the Stuart Room upstairs. The instrument for keeping a light, after striking it, was either a torch, or a candle, or an oil lamp. Oil lamps have been seen already in the Roman Room. There was no great change in their principle until modern times. Lanterns, equally, do not change in principle: there are examples in the Museum in various rooms. Candlesticks did not change: they were either prickets-spikes, with ornamental bosses or brackets, upon which the candle was stuck-or "sticks" of the patterns with which we are familiar. Both types are shown in different rooms of the 
Museum (see illustration, p. 49). There is a good hanging pricket in the model of a Stuart parlour in the basement.

Safety and other matches, as we understand them, came into use, roughly speaking, about 1830 : so did the wax or composition candles, as distinguished from tallow. Gas was first used for lighting purposes in I807, when Pall Mall was lit by it; but it did not become general for some time. That is one of the points to be remembered when we think of London of almost any past age: the darkness or the dimness when the sun had set. For more than eighteen centuries, London after curfew-couvre feu, put out your (dangerous) fire and light-was, as far as illumination went, like a modern country lane, except that in Tudor and later times there were in the chief streets link-boys, torch-bearers, constables with cressets (see p. 132), and a certain number of lamps or lanterns on the houses. The attendants of well-to-do persons carried torches after dark, to light their masters home through the dark roads.

The second case on the left in the Jewellery Room is chiefly occupied with badges and seals. There are here the seals and badges of some of the City Companies. It would be irrelevant here to describe the origin of those famous Companies (if indeed it were possible-it is a matter of much controversy). By the fifteenth century, however, they originally arose, they controlled the trade of London and of England. They had officers, as Froude says, "whose duty was to exercise authority over all persons pro- 
fessing the business to which they belonged; who were to see that no person undertook to supply articles which he had not been educated to manufacture; who were to determine the prices at which such articles ought justly to be sold; above all, who were to take care that the common people really bought at shops and stalls what they supposed themselves to be buying; that cloth put up for sale was true cloth, of true texture and full weight ; that leather was sound and well tanned; wine pure, measures honest; flour unmixed with devil's dust ; who were generally to look to it that in all contracts between man and man for the supply of man's necessities what we call honesty of dealing should be truly and faithfully observed. An organisation for that purpose did once really exist in England, really trying to do the work which it was intended to do. ... No person was allowed to open a trade or to commence a manufacture, either in London or the provinces, unless he had first served his apprenticeship; unless he could prove to the satisfaction of the authorities that he was competent in his craft ; and unless he submitted as a matter of course to their supervision."

That explains the need for such formal seals as these, and the pride with which such badges would be worn. The Companies to-day still admit Londoners to the freedom of the City, as they did five hundred years and more ago : and still their Masters and Wardens wear badges like these on occasions of ceremony. In a few cases-notably in the case of the goldsmiths and silversmiths-they still main- 
tain some supervision of their trades. But for the most part their great wealth is devoted less directly to its object, in grants for educational and similar purposes.

The Collar of the Bath is shown here. Upstairs, in a case in one of the windows of the last room (the room containing Royal Coronation and other robes), are three other " orders "-three varieties of the insignia of the Royal Order of Victoria and Albert, lent by Queen Alexandra ; and in the Costume Room is a blue Garter of the Most Noble Order of the Garter. The Garter Order was founded in the fourteenth century by Edward III, and is perhaps the most famous and honourable order in the world. The Bath is very little less ancient, having been founded in I399; but for fifty years or so (ending in I725), it ceased to exist. The Victoria and Albert Order-a different thing from the Royal Victorian Order-was instituted by Queen Victoria in I862, for ladies; but its membership has not been added to since the Queen's death.

A very different and sadder decoration is the badge of the beadle of Bethlehem Hospital (" Bedlam," as the old conversational speech pronounced it). That famous asylum, whose name has become a common phrase for any madhouse, was founded in the thirteenth century (see p. 62), and until I8I4, when the present hospital was built in Lambeth, stood north of the Thames, first in Bishopsgate, then in Moorfields. This badge, which dates from the eighteenth century, must have seen many dreadful sights: for in that century, and both later and 
earlier, it was a species of amusement to go to see the lunatics. Pepys sent his young relations there, for a treat, when he went to his office. Evelyn once, on his way home, "stepped into Bedlam, where I saw several poor miserable creatures in chains ; one of them was mad with making verses." Another record, of $I 753$, tells of " a hundired people at least, who, having paid their twopence apiece, were suffered, unattended, to run rioting up and down the wards, making sport and diversion of the miserable inhabitants." The beadle would show the most striking patients to visitors, and the unhappy inmates, generally speaking, were treated with a harshness that seems almost incredible. Public exhibitions of this kind, however, ceased about I780.

The Bluecoat School, or Christ's Hospital, of which another badge is exhibited, was a more pleasant and enlightened place. It was founded on the dissolution of the monasteries, on the site of the Grey Friars buildings (see p. 60). Edward VI himself instituted it, and the dress, still worn by its scholars, dates from his day. In the Costume Gallery, upstairs, there is a specimen of the "Blue Coat." It has altered only in the smallest details. A flat cap was given up forty or fifty years ago, but the rest of the garb is Tudor. The school was originally a charity, and received some eight hundred orphan boys and girls. While it has not departed from its original idea, it has now developed also into a great public school for boys : the girls' school is at Hertford, the boys' at Horsham in Sussex. Among other famous "Blues" may be 
mentioned Coleridge, Lamb, and Leigh Hunt. The buildings were pulled down in I902. Till then, Londoners could often stop to watch the boys playing football in the very heart of London.

Another badge in this case is a more cheerful matter. It is an old specimen of Doggett's badge - part of the livery known as Doggett's coat and badge. These are trophies rowed for on August Ist every year, by the young watermen of London, in a race from London Bridge to Chelsea, under the terms of the will of Thomas Doggett, a jovial actor who died in I72I. Doggett was one of the most skilful, amusing, and successful comedians of his day: " he had a different look for every different kind of humour." The coat that goes with the badge is of a bright scarlet with "frogs" or loops of braid.

The other cases against the windows and the wall opposite the door contain various pieces of plate of different periods, but they do not suggest any particular comment. The largest piece is a silver-gilt wine-cooler of the time of George IV: it is distinctly heavy in design, but its massiveness is so great as to be almost impressive. A gilt cup of $\mathrm{I} 62 \mathrm{I}$, in a case of silver ranging from Elizabeth to George IV, is a very beautiful work. A presentation vessel, in a glass case by itself towards the right end of the long wall, is perhaps the least graceful object in the Museum.

The case at the right end of the room contains objects other than plate and jewellery, for the most part. In the left corner of it are Jacobite and 
other portraits and miniatures ; among them a wonderful little portrait of Prince Rupert composed entirely of the finest seed pearls. In the middle are ivory and bone theatre passes-season tickets, as it were, for the two chief theatres-the Theatre Royal, Drury Lane, and His Majesty's, in the Haymarket. The oldest theatres of Londonthose famous wooden buildings where Shakespeare first played, the Globe, the Curtain, and othershave utterly vanished, and even their sites are no longer used for the same purpose. Fire destroyed them more than once; and in addition all theatres were shut, by law, during the Commonwealth. The theatres on sites still used for the same purpose were built in and after the Restoration period. Drury Lane Theatre, the earliest of them, was opened in I663, but this first (and rather inconvenient) building was burnt down in 1672. The new one was designed by Wren, and was opened two years later. This lasted till I809, when it too was burnt down in a famous fire.

The present building was opened in 1812 . It was sometimes spoken of in early days as Covent Garden Theatre, which is geographically an accurate enough name. Covent Garden Theatre itself, on the site of the present Covent Garden Theatre or Opera House, was not built till I732. Drury Lane Theatre was also formerly known as the King's Theatre. Its most important rival at first was the Duke's Theatre, in Lincoln's Inn Fields ; but this site has not kept up its theatrical connection. The chief rivals to Drury Lane a little later were the 
Little Haymarket Theatre (opened in I72I), almost on the site of the present Haymarket Theatre (built in I82I), and the Haymarket Opera House (opened I705), which rose where His Majesty's Theatre, the fourth on the same site, now stands.

Here also are a few Nelson relics, and among them a little torn rag of the Victory's flag. Behind them is a pocket-book or handy work-case given to the great Admiral Collingwood.

The cases against the wall nearest the door contain more plate, notably some spoons, besides the two-pronged forks already mentioned. The collection of spoons in the London Museum is one of the finest in existence, and each room from here onwards contains a number of them, according to the various periods. The earliest examples have straight stems, with a simple ornament at the top and a round or nearly round bowl : in outline they were rather like a Badminton racquet. In the sixteenth century came "apostle spoons," with the figure of an apostle as an ornament at the top of the handle. Another pattern of this period, or a little later, had a seal for head. Towards the end of the seventeenth century the bowl began to be slightly more oval, and the handle was broadened out into wider patterns at its head. In the middle of the eighteenth century the " rat's tail " appeared -a raised ridge on the back of the bowl, and the handle, instead of being straight, was slightly curved -upwards, not downwards: the downward curve came a little later, and with it the more complete concavity of the bowl, so that the spoons of George 
III's time were in shape practically like our own. Spoons for special purposes, of course, varied according to the purpose.

A hundred years or so of coffee-pots are also covered by the exhibit in this room. Coffee first came into use in London in 1657 , so that coffee-pots have naturally not a very ancient history: the berry had travelled westwards across Europe from Vienna, which had learnt the use of it from the Turks, who were perpetually at war upon the borders of what is now Austria-Hungary. Naturally, as the methods of preparing and drinking coffee have not changed very greatly, the coffee-pots are very similar in design. The differences between them are in the elegance of shape and finish of workmanship.

The period they cover-I686 to I773-might almost be called the age of coffee-houses. In the reigns of Anne and the first three Georges, the coffeehouses of London ruled public opinion, and settled the standards of taste in matters of fashion, in literature, in the drama, in a dozen different ways to which, perhaps, the popular newspapers of to-day are the nearest parallel. At them the wits met to gossip over their coffee or chocolate-and the " wits" really were "witty": they were widelyread, well-educated men of the world, whose idle life took itself very seriously. They talked of everything from China to Peru: they would discuss as readily the cut of a coat or the merits of a poem, the politics of the day or the latest acrobat. The coffee-houses, in one sense, were the beginning of the modern clubs, and clubs met at them : but there 
was this difference in coffee-house discussions, that they were open to any chance visitor who happened to come for refreshment. At them the newspapers of the day could be read; and the people who frequented them were those for whom and about whom the great essayists of the day-Addison, Steele, and their imitators-produced The Spectator, The Tatler, and other famous periodicals. The life of that day will be seen in closer detail when we reach the China and Costume Rooms on the first floor; but these coffee-pots, which must have ministered to many a gay lady in hoop and wig, and many a wit in a flowered coat, must always remind us of that far-off, artificial world which thcy served.

Pope, in a famous mock-heroic passagc, describes the ceremony of coffee-drinking in a private house ; in the coffee-houses it was less formal:

"For lo! the board with cups and spoons is crowned.

The berries crackle, and the Mill goes round.

On shining altars of Japan they raise

The silver lamp, and fiery spirits blaze!

From silver spouts the grateful liquors glide;

And China's earth receives the smoking tide.

At once, they gratify their scent and taste,

While frequent cups prolong the rich repast."

The chief glory of the Jewellery Room-indeed, one of the most remarkable possessions of the London Museum-has been left till the last. It is the "hoard" of precious things which fills the case in the middle of the room. It is not known for certain why this jewellery was hidden where it was found -in the earth in Wood Street, off Cheapside, the chief centre for gold- and silver-smiths' shops in 
London till late in the seventeenth century. It is not even known, strictly speaking, that it was hidden, though the circumstance that it was buried makes that practically certain. It is probable, from the position of the box containing the articles, and from the fact that there is more than one example of several of them, that they are actually part of a seventeenth century jeweller's stock-in-trade. Why they were buried, it is to be feared, can never be discovered: some alarm of the Civil War, even some local alarm of riot or thieves, perhaps fear of fire or of the Great Fire, or flight from the Plague, caused the owner to put them into the safe keeping of the earth, to await his return, or more secure times: and he never returned, and no man knew of the buried treasure till it was dug up, by chance, in I9I2, and handed over to the London Museum by Mr. Lewis Harcourt.

The striking feature of the collection is the extraordinary delicacy of the workmanship, and the beauty of the designs. The chains and pendants far surpass, in their exquisite shapes and execution, any other pieces of jewellery in the Museum. The little ornaments fashioned like bunches of grapes, with jewels for fruit, and golden filigree for stems, are in every way perfect. The chains, of various patterns, are delightfully proportioned, and finished to the tiniest details. The small flagons or tankards, of crystal and silver gilt, have been wrought by a worker who loved and honoured his work. Examine closely everything in this noble treasure. Whenever these things were made, by whomsoever, 


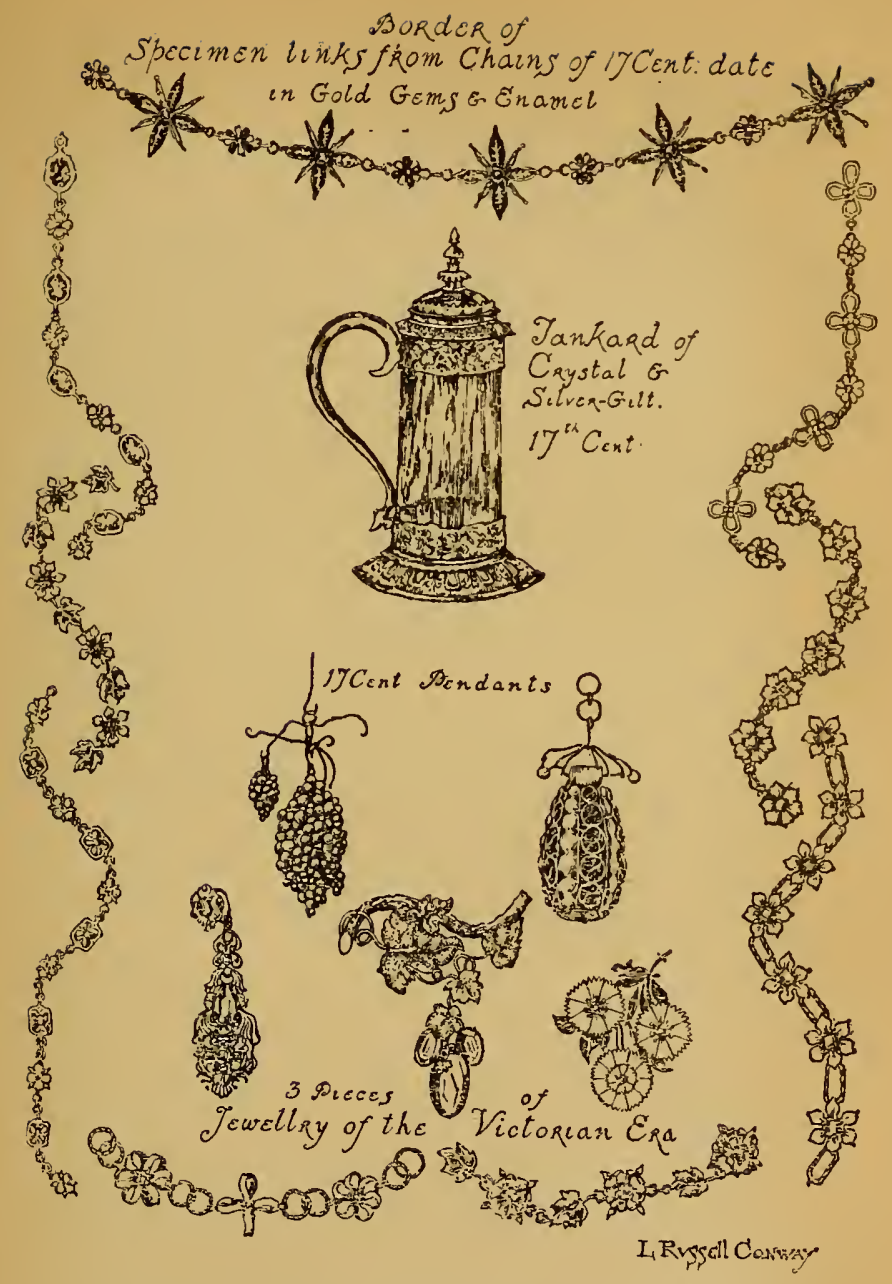

JEWELLERY OF THE SEVENTEENTH AND NINETEENTH Centuries 

they have been fashioned by one who saw in his mind's eye the loveliness of perfection-the fitness of every part, the harmony and the grace that nowhere sets too much gold or too large a jewel for the sake of display. There is a famous passage in Pepys' Diary in which the writer rather dismally estimates the worth of his two silver flagons, and concludes that they were worth five shillings an ounce for the metal, and five shillings an ounce for the "fashion "- the workmanship. The fashion of this hoard, fine though some of the jewels are, far outweighs the intrinsic value of the metal and precious stones.

It is well for the credit of the nineteenth century that a case of jewellery of that epoch exhibited (not far from the door) in the long Gallery of Costume on the first floor of the Museum is not shown side by side with this seventeenth century collection. There are indeed sufficient contrasts in the Jewellery Room itself, if one turns from the " hoard " to the Companies' insignia, or to the huge presentation vessel already mentioned. But this nineteenth century case supplies even a stronger contrast than these. Except for two or three of the smaller pieces, there is nothing in the case which is not utterly vulgar and ugly. It is well to preserve such things : they teach a harder lesson than is realised from looking at objects so perfect as to seem easy. They were made with the idea that jewellery must be valuable-that what is costly is necessarily beautiful. The inherent quality of jewellery is that it should adorn the wearer. If, of course, the wearer merely 
wishes to invest his savings in solid gold in a portable form, it is no use arguing with him-though it would be cheaper, if that was his purpose, to buy solid gold than to pay more for the workmanship. But if jewellery is not merely a way of carrying about your wealth on your person, if it is to be an ornament, not an advertisement of the amount of money you possess, then it ought to be beautiful. Ruskin, whose criticisms have not always remained so true, sums up the virtues of the most pliant of precious metals: "Goldsmiths' work is made to last, and made with the man's whole heart and soul in it. . . . Gold has been given us, among other things, that we might put beautiful work into its imperishable splendour." And he adds that so long as the buyer and the workman simply ask, "How much does it weigh?" "so long you cannot have a goldsmith's art in this country."

Thesefat and expensive nineteenth century objects, then, show us what jewellery should not be. But it is easy to condemn them too unreservedly. If they have no claim to be fitted for the true adornment of life, or to any ideal of beauty, they yet stand for something not much less necessary-for success in the struggle for existence. They were prized once, purchased once for a great sum by someone who knew the value of money: who knew, perhaps, even if in prosperity he had half forgotten the lesson, the happiness of toil and the pleasure of a dearly-bought gift. In the age when they were made, the trade of England grew into the trade of the world, and the London merchant was a mer- 
chant prince. He did not gain that position by inheritance-he made it ; and he and his craftsmen, if they had low standards of art and beauty, had high standards of honesty and conduct.

Jewellery, as has been said, is always an intimate thing-something personal, something chosen with more care than objects of daily use. These nineteenth century pieces, in their solid unloveliness, have yet the pathos of great possessions. There is a wonderful little play by Sir J. M. Barrie, The Will, which they recall in an odd way. In the first short scene a young man just married is about to make his will : he has only a few pounds to leave, but he is desperately eager to let his wife have the full benefit of what seems to their trembling happiness a great inheritance. In the second scene he is winning, in the third he has won, a fortune; and he is embittered by wealth, and remakes his will with capriciousness and sadness. These are the brooches and necklaces he would have chosen for his wife : first of all, when he was young, to show her his love by the measure of what he spent ; last of all, when he was old, to show other people, by the same standard, what they were to believe his love still was, and what they were to see his career and his wealth could achieve. Old jewels are the most human of things : there is nothing so sad-so full of dead and untold hopes and fears, of little joys and sorrows no words can ever be subtle enough to make plain.

It is pleasant to record that though London in the past has often learnt her gold- and silversmith's 
craft from abroad, to-day she can teach rather than learn. Modern English jewellery, at its best, shows little of the vulgarity and ostentation of the last century. Societies like the Art Workers' Guild and the Arts and Crafts Society have influenced the craftsmen themselves, and set a standard: while London itself has realised a high ideal in the craft schools established by the County Council, and in particular, in the work of Mr. Harold Stabler and his pupils, whose work has deservedly won high awards at foreign exhibitions. 


\section{CHAPTER VI}

THE TUDOR ROOM

ThE Jewellery Room, like the corresponding Roman Room at the other side of Lancaster House, is a " blind alley." To reach the other parts of the Museum it is necessary to re-enter the Mediæval Room and then go through it towards the left, into a spacious passage which leads into the Central Hall once more: it contains pictures of the frescoes of the House of Commons. Here it is possible to visit either the first floor or the basement: but as the chronological order is continued directly on the first floor, it is advisable to go upstairs, by way of the right-hand half of the gorgeous main staircase. The staircase ends in a landing, on the left of which is the entrance to the first floor galleries. Just outside the entrance is a valuable exhibit lent by the King-an oak cradle, probably of the fifteenth century, from Chepstow.

There are a few small prints on the walls to the right of this cradle, and then comes the opening to the Tudor Room. It is small, but crowded. On the right-hand wall is a large collection of little domestic objects-knives and scissors, combs, a piece of chain mail, an archer's gauntlet, a gipcier mount (which shows the continuity from the Medi- 
æval Room). Underneath are some books printed during the period (I500-I600, roughly); and one of the objects shown is a Bible chain. Books being still very valuable in Henry VIII's reign, it was found necessary to chain them to the bookcase or desk or lectern. Many churches still possess their chained Bibles: probably the largest collection of such books in their original state is that at Wimborne Minster.

On this wall also is a long picture of jousts held at Westminster; and now, with the domestic objects, the pageantry of the tournament, the command of Henry VIII, and the books, there is enough evidence to give some idea of what the Tudor period meant to London : it will then be possible to see how well the Museum brings out that meaning.

First of all a great deal is known about domestic life of the period. The spoons in this room, for instance, suggest a high degree of luxury and finish in the smaller details of daily life. Against the wall nearly opposite the door is a further and more vivid proof of this - two superb pieces of glass, one Italian, the other manufactured-perhaps by Italian workmen-in London, in Crutched Friars. In the sixteenth century Venetians were first brought to London to encourage the making of fine glass, in which, then as now, they excelled. The two bowls are marvels of delicate workmanship: the pattern is like lace made by a spider.

The glass, and some delft pottery close by, are examples of the way in which foreign immigrants broadened and improved London trade. Not only 
Venetians but Frenchmen made glass in London in the sixteenth century-glass infinitely better than the thick, dull, home-made article. The result was that in the succeeding century glass-making was a flourishing English industry, and still later, in the eighteenth century, flint-glass (the normal glass of to-day) was actually invented and first made in England-probably in London. The importance of delft ware will be seen later (p. I40).

In the case to the left of this are two sets of cake platters, richly ornamented. A little earlier, only the rich could afford plates, and these plates were of metal-pewter, silver, or gold: poor persons used trenchers-slabs of bread or toast baked firm, which when they were thoroughly soaked with the dregs of food could be given to the dogs-or to even poorer persons. These decorated platters show a great advance-an adaptability which is the sign of a vigorous progressive civilisation; when persons of fashion vary their possessions, less eminent people are likely to get some benefit from the changes.

In the same case are (among other things) two more notable objects-Sir Thomas Gresham's steelyard, or balance, which will be dealt with presently, and a pewter dish bearing Queen Elizabeth's cypher. The dish has a curious history: it was found, doubled up and battered, at Westminster; it had evidently been thrown away by the Queen's servants as worthless-a fact which in itself tells a tale which does not need to have its moral emphasized here.

There are in this and the neighbouring case many 
other things of interest on which it is impossible to dwell now-cups, pewter plates, shoes ("slashed" according to the fashion of the day, to match the slashed sleeves and doublets and hose : an under colour showed through the slashes), glass vessels of various kinds, much finer than any glass produced in England before that time, buckles, chessmen, (chess, an Eastern game originally, is far older than the Tudor period), pins, spurs, rosary beads, girdle chains, books, gloves, candlesticks, and all manner of objects which once were the everyday possessions of Londoners. In the right-hand window is a fabric of value for the history of child life in England: it is the earliest known "sampler." It bears the arms of Queen Elizabeth. The sampler was an elaborate method of learning fine needlework, which was practised till late in the nineteenth century: specimens older than the eighteenth century are very rare. This example shows that people were beginning to find occupation-amusement, perhaps, they called it-for children outside the teaching of the alphabet and the strict education in languages and manners which well-to-do young people had hitherto received. There were no books for children yet-nor for a century to come-and not many toys: but the sampler was at least a beginning in the way of recreation, even if it was a dull and difficult one.

In the other window is a hardly less rare treasure -a pedlar's pack. It throws light on the life of the country rather than London, though doubtless many such a pack was made up by the rich mer- 
chants of the city. It is hard to realise nowadays what a pedlar's arrival in a country village meant: but sometimes it is possible to get a faint idea. A few years ago the writer was staying in a

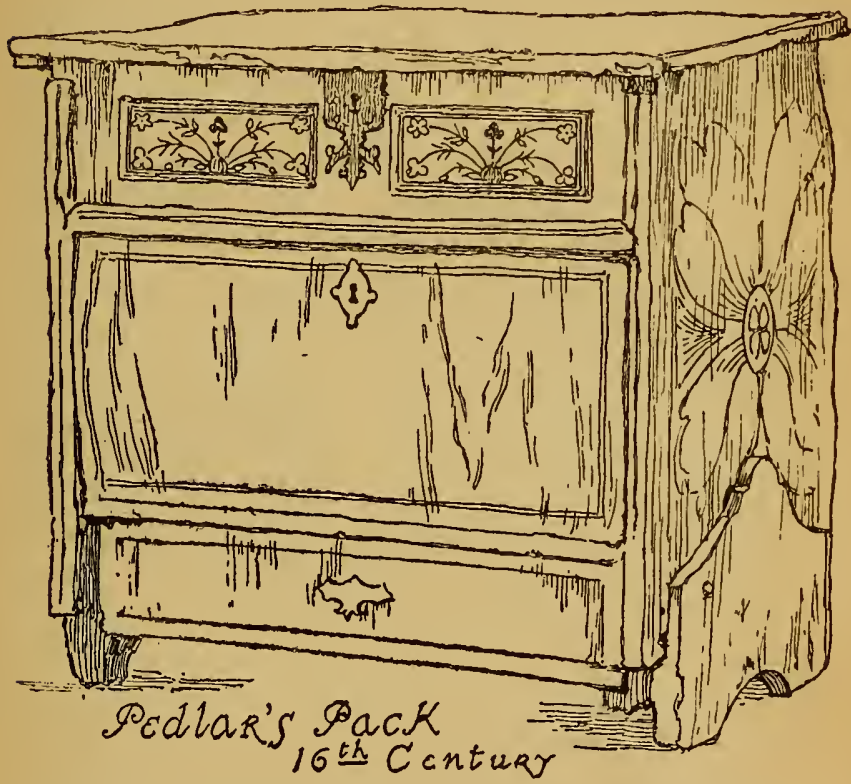

village some fifty miles from London, and five miles from a railway station. It is a village with two grocers' shops, one butcher's, one baker's, one greengrocer and dairyman's. A great railway strike broke out. Within a few days the price of everything was doubled, and certain foods could not be obtained at all. All supplies-in spite of motors and other vehicles and excellent roads-depended 
entirely upon the railways, and the local producers were so accustomed to sending their wares to London that they could not quickly change their methods and sell them nearer home. In fact, the village was for a short period thrown back four hundred years. Of course, in Elizabeth's day, food supplies were well managed locally: but manufactured articles had usually to come from afar, and the state of affairs must often have been similar to that just described. What is more, there was in this Sussex village a further example of the pedlar's difficulties. A few hundred yards from the main road to London runs the old pack-horse road. It is a grass-grown lane some ten feet or so wide, on an average; very muddy when there is the least rain, unpaved, a mere track between hedges. That was the high road in Elizabeth's time-an inferior lane of to-day. Along it stumbled pedlars with those great wooden boxes bowing them down and making their footsteps heavy.

The reproduction of a stained glass window shows how the pack was borne. Practice doubtless would make such a burden easier; but it is probable that in some ways the Elizabethans were stronger than we. They bore pain as no one could bear it now : they fought sometimes with a demoniac fury which few could feel to-day: they lived in perhaps the cruellest age in history. That they endured hardships thus does not mean that we are degenerate: we are not: but in many directions we enjoy greater ease, and so have lost, to a certain extent, their insensibility to discomfort. 
The pottery in this room is significant. The shapes of the vessels are beginning to change, and the glaze is becoming much finer and more varied. The Tudor period, in fact, shows the beginning of English pottery as a fine art, not merely as a trade which supplied bare necessities. The politics of the Tudors led to a good deal of intercourse-social rather than warlike-with foreign nations, and especially with the Netherlands and Flanders, re-

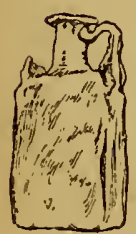

Romard Glass Bottle

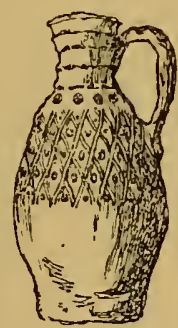

$14^{\text {" }} \mathrm{C}_{\text {Ent: Earthenhare }}$ JAR

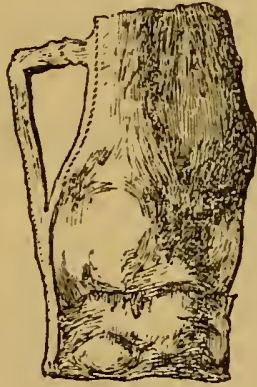

Leather Jug of COMMGNWEALTH TIME

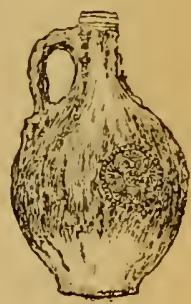

BeLLARMINE V/ARE $17^{\circ} \mathrm{C} E N T$

gions in which pottery was flourishing. Two Flemings, in 1570 , settled at Norwich and set up pottery workshops there, producing fine wares in their native manner, and so benefiting the English craftsmen by their example. The numerous examples of "Bellarmines" or "Greybeards," in this and the next two rooms are instances of this foreign influence. These jugs receive their names from Cardinal Bellarmine, a famous anti-Protestant writer of Rome, who died in I62I : the jugs were not necessarily first made with a likeness of the Cardinal_ it 
is possible that an old pattern happened to resemble his features. The pattern became a standard one even for potters who might never have heard of the dignitary whose portrait they tried to model.

A strong substitute for pottery, used especially for "jacks" (huge jugs) and small barrels with handles, was leather, waxed and tarred. In the case opposite the door is a leather black jack; the next two rooms contain even larger specimens.

Near the exit door is another exotic producta Nonsuch chest. Nonsuch Palace stood a little way out of London, in Surrey. It was very wonderfully and lavishly decorated in the most ornate Continental manner. Pepys saw it-" all the house on the outside filled with figures of stories . . . most of the house is covered with lead, and gilded." It became a byword for magnificence, and so struck the English fancy that all kinds of objects were manufactured with similar diffuse ornament, and labelled "Nonsuch." There was a Nonsuch House on Old London Bridge : the model in the Basement, already referred to, shows it. We in our own day have not lost this trick of imitation, in a small way: when the Eiffel Tower in Paris was built, English shops were full of Eiffel Tower wares-inkpots, paper-weights, ornaments, and so on. The Nonsuch Chest is the same in idea, but more beautiful in execution. Nonsuch Palace was eventually given by Charles II to one of his favourites, Lady Castlemaine, who pulled it down.

Return now to the case near the window, on the farther side of the room from the entrance. Here 
are some objects hitherto passed over-the greater part of a doublet, a rapier, very delicately wrought (probably made by Italian workmen in London), some flat caps (it is very unusual to find such things so well preserved), an apprentice's staff, and an archer's bracer, inscribed "Well shot." (A bracer was worn on the inside of the left forearm, to break the force of the bowstring as the arrow was loosed: even when a bracer protects the arm, the string can still strike a painful blow.) These objects bring us right into the social life of the London apprentices - the young City men of the day, who had a habit of objecting forcibly to what they did not like. Riots were not at all uncommon; but the worst of all took place on what was afterwards known as Evil May Day, in I $_{5}$ I7.

The citizens were very jealous of the foreigners who were settling in England in such numbers: they thought, not unnaturally, that the aliens would deprive them of trade, not realising, as we can now, after the event, that the superior foreign craftsmen would set a higher standard and so encourage fuller trade. On May Day it was customary to go into the fields round London for sport and amusement -just as on a Bank Holiday Londoners now go to Hampstead and Richmond, and similar places a little way out of the City. There was already a great deal of resentment at the way in which "the towns about London, as Islington, Hoxton, Shoreditch," had enclosed the fields outside the City walls, and, prevented, among other things, the sport of archery: in I5I4, indeed, the citizens had taken 
the matter into their own hands, and levelled the new hedges and ditches with spades and shovels. So probably in $\mathrm{I}_{5} \mathrm{I} 7$ they were still dangerously suspicious of anything they disliked--such as aliens. Certain foreigners, on April 28th, had been assaulted by apprentices, who were sent to prison for their misconduct. Somehow a rumour ran round (" and no man could tell how it began ") that on May Day the citizens would kill or expel all aliens.

May Day came: the Aldermen, hearing the rumour, issued an order that everyone should remain indoors. But one of the Aldermen found two young men in Cheapside playing a game, apparently in ignorance of the order: many others were looking on. $\mathrm{He}$ bade them desist, and after argument tried to seize one of them, whereupon the rest raised a shout of " 'Prentices and clubs." At that familiar battlecry, " out at every door came clubs and weapons," and the Alderman had to flee for his life. More 'prentices assembled, and the whole body went about the City, breaking into the lock-up houses, and plundering shops and houses, especially those of foreigners. It was not until several hours later that they dispersed; and when they scattered to go to their homes, over three hundred were arrested and imprisoned.

Never again, after Evil May Day, was the City maypole set up in Cornhill. Only its name lives in the church of St. Andrew Undershaft-St. Andrew under the shadow of the maypole.

That was neither the first time nor the last that the 'prentices proved unruly; and later in the six- 
teenth century strict rules were passed for their conduct, covering almost every detail of life, down to their very clothing. They had to wear the apparel given them by their master, which was, ordinarily, " a flat round cap, narrow falling bands, coarse side coats, close hose, cloth stockings:" they also wore blue cloaks in the summer, and blue gowns in the winter. They might show no ruffles, cuffs or loose collar, and carry no sword, dagger, or other weapon, but only a knife.

The doublet in this case, then, was that of a wellto-do man-perhaps even that of a "page" at court : the pages were wont to call the apprentices, in derision, "flat-caps." The staff and bracer may well have been used by some of those identical young citizens who created the famous riot of Evil May Day, just as the rapier was probably the handiwork of the very foreigners whom they detested so bitterly.

That, therefore, was the life of the younger Londoners. To draw near to the wealthier citizens, look again at Gresham's steelyard, in the central case on the side of the room farthest from the entrance. It is one of the most highly prized possessions of the Museum, for many reasons : for one thing, it is a unique piece of metal work, and for another, it is a relic of one of the greatest of Londoners. "Sir Thomas Gresham, mercer, I566, built the Royal Exchange in London, and by his testament left his dwelling-house in Bishopsgate Street to be a place for readings, allowing large stipends to the readers, and certain almshouses for the poor :" that is Stow's simple entry in his summary 
of the "Honour of Citizens, and Worthiness of Men in the Same." In his charities, Gresham did not differ greatly from many others of the noble merchants of London, from men like Sir Thomas White, William Lambe, John Fuller, Sir John Allen, or Sir Andrew Judde. The names of such benefactors are to be seen to-day in all parts of England and London, at the Guildhall, perhaps, more than elsewhere. But Gresham's founding of the Royal Exchange was an act of foresight as well as of generosity. With the world-wide discoveries of the sixteenth century, and, towards the end of it, the adventures of Englishmen upon all the seas of the globe, London's trade was increasing more rapidly than could be accommodated in its old streets. A common Bourse or meeting-place for merchantsmen from all parts of England and the continent, not Londoners alone-was surely needed. Gresham undertook to give the building if the City would purchase ground. On June $7, I_{5} 66$, he laid the first stone: by November 1567 , "the same was covered with slate, and shortly after fully finished." A little over two years later "the Queen's Majesty, attended with her nobility, came from her house at the Strand called Somerset House, and entered the City by Temple Bar, through Fleet Street, Cheap [-side], and so by the north side of the Bourse through Threadneedle Street, to Sir Thomas Gresham's in Bishopsgate Street, where she dined." After dinner she inspected the new building, " every part thereof," and " caused the same Bourse by an herald and a trumpet, to be proclaimed the Royal 
Exchange, and so to be called from henceforth, and not otherwise." And so it has been called ever since, though the first Exchange perished in the Great Fire a hundred years later, and a second building also was burnt down in 1838 .

In the basement are pictures of the second Exchange, of the fire of 1838 , and of the opening of the present building by Queen Victoria. To-day Gresham's sign-the grasshopper which forms the weathercock at the Royal Exchange-still stands over the same site on which he built two hundred and fifty years ago.

This steelyard was ordered by Gresham for his Exchange, though its history is not fully known. It is dated 1572. Some of the work in it is of later date: the little figures (said to represent Gog and Magog) were probably added in the seventeenth century. The name steelyard is itself significant : it implies a great branch of London's foreign trade. The Steelyard (roughly where Cannon Street Station now is) was " the place for merchants of Germany," who in return for privileges undertook to keep Bishopsgate in repair. "Steelyard " is a mistranslation of "staal (sample) yard." A standard balance, or weighing machine, was kept there, and so the term steelyard came to be applied to any balance.

From Queen Elizabeth's visit to Gresham, we are led to the general position of London in regard to England and the sovereign. By the sixteenth century, London had become thoroughly national. It was no longer a city fighting for its privileges and its very existence, though from time to time the 
citizens were forced to uphold old rights and customs against State interference. It was the capital of England, a great city of the world. In Tudor days it saw many pageants like the jousts at Westminster coronations, marriages (Philip of Spain, when he married Queen Mary, brought to the Tower of London ninety-nine horseloads and two cartloads of gold and silver), the reception of ambassadors and envoys, processions on the Thames, Lord Mayor's Shows, whose far-off origin is unknown, departures of sailors and soldiers, visits by the great Queen to her navy at the time of her Armada, or to Drake's ship, the Golden Hind, as she lay at Deptford after her wonderful voyage "round about the whole globe of the earth." It must have been a gay and lovely city, even if its streets were narrow, dirty, and too crowded for the ever-increasing volume of traffic. Brightly painted signs, rosy red brick, gleaming black and white, halftimbered houses with overhanging gables (like those of Staple Inn, at Holborn Bars, to-day): nobles with gorgeous doublets and hats, merchants in grave and splendid robes, blue-cloaked apprentices - it was a many-coloured city.

But it was also at times grim and terrible. Tower Hill, in the sixteenth century, saw many executions in Tudor days: no sight in the world, perhaps, can have been more full of horror, with the executioner in black, the red uniforms of the Yeoman, the forlorn little bare-necked figure bowed over the black block in the open space of the great yard. On the wall of the Tudor Room, near the exit door, is a 
reminder of these sombre scenes: the warrant for the arrest and execution of the Earl of Northumberland.

There was one other horror in Tudor London. An old chronicler of the twelfth century says that "the only plagues of London are the immoderate drinking of fools, and the frequency of fires." Stow, three hundred years later, says that the drinking still continued: it is not ended yet. Fires there were still in plenty, though the use of stone and tiles for roofs instead of thatch had abated the danger: and there was a greater fire yet to come. But there was a new plague by Stow's time-the plague, or rather, the various epidemics which were indiscriminately called plague. Such epidemics were not infrequent : for all its good water supply, and the strict order kept, London was utterly unsanitary, and the narrow streets, closely packed houses, and general ignorance of proper treatment caused any contagious or infectious disease to spread as quickly as a fire. In the left-hand window of the Tudor Room is a little framed print, a rough, discoloured woodcut, inscribed, "Lord Have Mercy upon Us." It is a relic of the awful outbreak of typhus fever in I592-3. A list of the regulations for dealing with that plague has survived. Inquiry was to be made " what houses be infected." Constables had to report cases to the Aldermen, in writing, and to provide women to carry necessaries to infected houses. Clerks and sextons had "to see bills set upon the doors of houses infected "- this woodcut is such a bill. Infected houses were to be shut up, 
and none to go in or out, for twenty-eight days : various methods of airing and cleansing were to be adopted; and " two viewers of dead bodies and two viewers of sick suspected" were to be appointed and sworn, with a penalty of the pillory for making false reports.

Ten years later came another outbreak, in which over 30,000 people died.

In this room also begins the fine series of prints and drawings with which the Museum is so well furnished. The chief ones here are by Dr. Philip Norman, an enthusiastic historian of London.

That, then, is a little of the story of London under the Tudors. There is much that cannot be added here: the story of Shakespeare and his theatres, of the religious persecutions, of the great literature of all kinds inspired by and written in Elizabethan London. All Lancaster House would not suffice to display that history in detail. This one little room gives, as it were, a bird's-eye view of one of the fullest and most memorable of London's centuries of life.

The Basement also contains some exhibits of the Tudor period : in particular a piece of ship's timber and some stone cannon balls, dug up from the Thames at the end of I9I2. It is not known for certain what ship thus lay so long drowned, but it seems probable that it was either the Great Harry, a man-of-war built for Henry VIII, about I52I, or the Pelican, one of Drake's ships, "which was long preserved at Deptford, as a monument of Drake's voyage [round the world], and is supposed to have 
been removed to Woolwich some time in the eighteenth century." 1

Under the Tudors many suburbs now almost in the heart of London began to grow populous. Bloomsbury, Holborn, Piccadilly, Poplar, Blackwall, Islington, Hoxton were all what now would correspond to Richmond, or Surbiton, Epsom or Bromley-though they were distinctly cut off from the City by fields. The Strand, literally a strand, or river bank, was an avenue of palaces, with gardens running down to the river. Bankside, the Southwark shore, was a place of pleasure gardens and theatres. Whitefriars became "Alsatia "-a warren of obscure streets and lanes where rogues and fugitives from justice lived in a lawless community of their own. The population was about I25,000.

There are in the Basement, besides some less notable objects which will be mentioned when the Basement as a whole is treated, models which belong especially to this period. Those of London Bridge and the Tower have already been mentioned. There is one of Old St. Paul's as it was in 1560 - one of the most beautiful cathedrals of Christendom. The next year, I56I, the lovely spire was struck by lightning, and "within the space of four hours the same steeple, with all the roofs of the church, were consumed, to the great sorrow and perpetual remembrance of the beholders." Contributions were immediately made

${ }^{1}$ See Sir L. Gomme's London (Williams \& Norgate, 1914), Appendix VI; the quotation is from the Times. 
by the Queen, the City, the clergy, and many private persons, for rebuilding the steeple: but, says Stow mournfully, "Divers models were devised and made, but little else was done, through whose default, God knoweth. It was said that the money appointed for new building of the steeple was collected."

The spire was never rebuilt: the Cathedral remained with its mutilated stump till the whole was burnt down in the Great Fire.

Other Tudor models are those of Cheapside in I580, and of the mouth of the river Fleet in $I_{550}$. They are so well described by labels that it is not necessary to say much of them here. The most striking features in Cheapside are, perhaps, the Cross and the Conduit. The Cross is said to have been one of those set up by Edward I wherever the body of his Queen Eleanor rested on its way to Westminster Abbey. It was pulled down by the Puritans in I643, to the sound of trumpets. The Great Conduit, or fountain and "tap," was first made in 1285 : it was rebuilt and enlarged in I479. On great occasions both it and the Little Conduit (at the west end of "Chepe") ran with wine, and were the scene of pageants and shows.

The Fleet to-day is a drain, like other streams of old London. It enters the Thames under Blackfriars Bridge. This model shows Baynard Castlethe western fortress of the City wall, corresponding to the Tower on the east - still standing, the Blackfriars monastery buildings (see p. 6o), and Bridewell Palace. Bridewell House, or Palace, was 
built by Henry VIII in I552, and was used for various state purposes. But Edward VI, in I553, presented it to the City as a " house of correction" or prison, and for other uses also. In the eighteenth century it was a common amusement for idlers or country visitors to go to Bridewell to see the prisoners whipped. It was rebuilt in I668, and pulled down in $\mathrm{r} 863$. There was a dock between the Palace and the Whitefriars buildings to the west, while the Fleet River separated it from the City on the east.

A model of Gresham's first Royal Exchange is in preparation. 


\section{CHAPTER VII}

THE EARLY SEVENTEENTH CENTURY AND

COMMONWEALTH ROOMS

THE Tudor Room leads into a room named the Seventeenth Century Room. It deals only with the first two Stuart kings, and the transition from the Monarchy to the Commonwealth, and it will bc convenient to consider it and the next room (the Commonwealth Room) together. Though the state of society naturally differed greatly in the two short periods covered by these small rooms, the gear and fabrics of the periods were much the same. It was at the Restoration that England in London began to take on a new aspect in outward appearance as well as in the lives of the people.

Stuart London-it will be convenient to label the reigns of James I and Charles I "Stuart," and those of Charles II and James II " Restoration" - Stuart London was full of contradictions, to judge by the contents of these two rooms. It had become, as has been said, national rather than local : that is to say, the affairs with which it dealt corporately were in the main national affairs; but at the same time it lived a domestic life as consistently as was possible in such days of public tumult. 
To take the domestic life first, as it is more prominent in this part of the Museum. The first case on the left in the Seventeenth Century Room contains, among other things, some excellently constructed little cases of weights. Recall Gresham's steelyard, and think of the difference. Of course, one was a public weighing machine, the other a private one; nevertheless, that fact itself is significant. It was worth while to turn out these "pocket" sets in some quantities (the weights were cast from moulds, and a mould almost invariably means a good many copies, or it is not worth the trouble of making). That is to say, trade was becoming more like the trade of to-day-more individual and varied: it was not a matter for assembling formally and solemnly in a public hall, or seeking out one particular quarter of the city for a particular business (even in Stow's time the trades were becoming less local and more generally diffused).

On this wall is a case of spoons : compare them with the Commonwealth spoons in the next room. There is, perhaps, not a very wonderful difference, but the Commonwealth examples are plainer and more severe.

The coins, badges, and medals may be passed over for a moment. Look at the large piece of furniture, half sideboard, half chest, in the lefthand corner. It is full of strength and solidity, yet graceful. It has not got quite the artistic, conscious beauty of later furniture (of the eighteenth century, for instance), but it is not heavy or cum- 
brous in design, nor is it florid. It is a sign of a transition in taste. The terra-cotta head above it, perhaps, proves nothing for certain, except that some one in London knew fine work when he saw it. It is a singularly beautiful example of Italian work; the fact that it belonged to a Londoner (it was found in the Thames) simply shows that there was some trade in such things, or that some Italian artist in London could make them, or else that the original owner travelled abroad, as Englishmen were now beginning to do with greater frequency.

The mirror close by, and the clothing, dressing cases, caps, and objects in the cases on the other side of this room are evidence of another phase of social life. What faces, what hopes or fears that mirror has reflected: with what simple pleasure or less simple vanity those dressing cases were opened: who drew on so proudly those gloves wrought gloriously with seed-pearls: who put his faith in that fine little gun, or felt safe and bold in the stout leathern jacket, we can never know. The bright colours are a little faded now : the bright hopes that once looked on them are dead. We can only say that in these things, too, our unnamed forefathers found pleasures or sorrows not in any way different from our own.

The workmanship of the mirror and dressing cases deserves close attention. No machine to-day, however complicated, however swift, can reproduce the delicacy, the personal touch, of these laborious handiworks. This was a great age of needlecraft. 
Against the wall farthest from the windows is a collection which, in some ways, is very near our day. It contains clay pipes, and pipe-stoppers of various designs. There are others in the Commonwealth Room. Tobacco, " the Indian weed," as everybody knows, was probably introduced into England by Sir Walter Raleigh at the end of the sixteenth century. The number of these pipes alone-for clay pipes are very frail things-shows how rapidly the habit of smoking must have spread, in spite of James I's hostility to it. Towards the end of the seventeenth century, and throughout the eighteenth, it increased still more, and Bristol, the chief tobacco port, had an immense trade with Virginia. Except for the use of other materials as well as clay, and some trifling developments in design, there is not much change in pipes from Stuart times to the present day. The pipe-making industry is a very old one. At Broseley pipes have been made for three centuries, and the Broseley " churchwardens" were widely celebrated. Winchester, Derby, and Exeter also manufactured them in early days. ${ }^{1}$ The stems, or specially made tubes of similar shape, were used in the eighteenth century for another purpose than smoking-for "putting the head in pipes." They were wig-curlers, the strands of hair being wound tightly round the stems and so left for a time.

Other exhibits which hardly call for comment are the rushholder (in the Commonwealth Room; see p. 49), the knives, the scriveners' instruments

${ }^{1}$ See The A B C of Collecting Old English Pottery, by J. Blacker. 
(the use of which is obvious), the cloth marks and implements, the combs, the needles and thimbles, the torch strongly made of tow threads and wax. They show various natural occupations and interests of the day, as do the tremendous jack boot, the fine broadsword, the rushholder, and the huge leather jack in the Commonwealth Room (see p. 93). The little top in the latter room is a reminder that through the Civil War children were growing up to whom the war could be not much more than a 'bewildering, and sometimes terrifying, game: they were to be London's citizens of a more peaceful generation. The watering-pot in the Commonwealth Room is of a strange shape; it is a peaceful comment on the times of civil strife. Native English gardening, perhaps, reached one climax in its history under the Tudors: a new impulse was to come when William and Mary introduced the formal Dutch fashions.

Two other domestic objects in the Stuart Room are of strange interest: through them we are led very close to the most private thoughts of Londoners long dead. One is in the case at the end of the room farthest from the windows, on the right hand, the other in the central case. The first consists of eight farthings of James I's reign, found concealed in an old shoe. Who hid that poor little hoard, and why? The second and unique exhibit is a bundle of hair and nails. It is a relic of the belief in witchcraft. If you had an enemy, you obtained somehow a lock of his or her hair, and put it in a bottle with some nails and buried it: 
as the hair decayed, so would the enemy waste away in health. It is seldom that these fantastic treasures are dug up : this was found in Rathbone Place : but who the spell-binder was, who the bewitched, none can say.

Witchcraft, indeed, was a topic of more than usual moment in the reign of James I, who took a deep interest in the subject. It was not a superstition of uneducated folk alone : many learned men accepted it. Nor is it certain that some of the "witches" were not, in a sense, guilty of some of the offences for which so many died a terrible death. When all the conditions of thought in an epoch are favourable to such dreadful imaginings, women and men could, without doubt, work themselves into an hysterical belief that they possessed vile powers.

The pottery of the period in both rooms, again shows development. There are, as before, plenty of Bellarmines, of foreign pattern (see p. 93). But there are new native patterns, like the tyg (a loving cup with several handles), and the fuddling cup. This last was an ingenious device to make a man drink more than he expected. It was a group of small cups joined together, and the drinker might think that he could, if he pleased, empty one cup, and so take but a moderate draught. But all the cups communicated with one another, so that to empty one he would have to empty the whole-and be fuddled. Puzzle jugs are practical jokes of another kind. They are of all manner of patterns, but the principle of them all is much the same. It 
is impossible to pour the liquid out of them unless a certain hole is stopped with the finger, or (in some cases) unless the vessel is held at a certain angle, or unless a certain hole only is used.

In addition to this rough but welcome humour, the pottery begins to display an individual decoration. The Puritans, in particular, liked their cups and jugs to point a moral. In the Commonwealth Room are glazed vessels inscribed with texts or mottoes in "slip" (a wet coloured paste put on and fired after the earthenware pot itself has been shaped and fired). Most of the black ware of this kind was made in Staffordshire and Derbyshire: the red wares are usually from Wrotham or London ("Metropolitan " ware).

In the Basement is a well-arranged "interior," which should be mentioned here, though it is not Stuart or Commonwealth in all its details. It is a reconstruction of what a small seventeenth century room must have looked like (see Frontispiece). The two figures are in the costume, approximately, of Charles II's reign. The iron and stone fireplace is of the sixteenth century, the panelling, the candlesticks, the warming-pan, and most of the smaller objects, of the seventeenth. The outside of the room consists of seventeenth century London doorways, very simple and solid, some fine oak corbels (beam ends under a roof, supporting the weight of the roof) and wooden pilasters. Outside are two old signs of the same period or a little later. The whole gives a good idea of the look of domestic scenes when the Stuarts ruled or misruled England. 
The models in the Basement also have reference to this period. Here is Charing Cross as it was in I620, with the cross and the pillory, and Whitehall Palace rising in the distance. Charing Cross itself (not the present erection in the station yard) was set up in I29I to mark the last place where the body of Queen Eleanor lay before burial in Westminster Abbey. It was pulled down by the Puritans in 1647 . Proclamations, executions, pilloryings took place on the site for generations. In a sense, Charing Cross is the very centre of the world-the chief meeting-place of east and west, north and south, in the world's capital. It has been said by a great traveller that if you wish to meet a longlost friend, you should wait for him at Charing Cross : he will turn up sooner or later. Dr. Johnson's famous sentence- "I think the full tide of human existence is at Charing Cross" -is hardly an exaggeration.

Whitehall consisted originally, for the most part, of a great palace and its offices, built by Henry VIII. It suffered severely from successive fires in the seventeenth century, and nothing is left of the original Tudor building. The only remnant of the palace standing to-day is the beautiful Banqueting Hall, now the Museum of the Royal United Service Institution $^{1}$ : it was built in the reign of James $I$, from the designs of Inigo Jones. All the rest of the palace was burnt down in the reign of William III, in 1698 , after which it ceased to be a royal

${ }^{1}$ See Greenzwich Hospital and the United Service Museum, by Edward Fraser, in the Treasure House Series. 
residence. It had been the seat of the Court for over a hundred and fifty years. From the Banqueting Hall Charles I walked to his execution on the scaffold erected in front of the building; and on its roof, by the weathercock which still stands, James II watched for a wind that would bring or repel the fleet of William of Orange.

The London Bridge model really belongs to this epoch, though, as has been said, it will serve as well for some generations earlier.

These models bring to mind a great Londoner, who is (of necessity) not commemorated in the Museum : John Stow, the chronicler. He was a poor tailor of London, who loved his native city, and spent his life in collecting information about it. Without his great Survey of London, published in $\mathbf{I 5 9 8}$, the fruit of years of labour, no history of London would be possible, and such models as are in the London Museum could not be made. Stow made a little money by his trade, but he made none out of his books. All his reward in his lifetime was a grant from James I permitting him to beg for contributions to his expenses. So this " very aged and worthy member of our City of London " toiled obscurely, working for love of his city and for the benefit of those who came after. "He always protested never to have written anything either for malice, fear, or favour, nor to seek his own particular gain and vain glory: and that his only pains and care was to write truth." He died in the reign of James $I$, in 1605 , and was buried in the church of St. Andrew Undershaft, hard by the spot 
where once stood the maypole. The maypole might stand for a symbol of the old buildings of London, broken and lost beyond recall ; but the work of John Stow, with all its faults, is no less a symbol of the undying spirit of London's citizens. Stow was that kind of patriot which knows that in the strength and purity and hope of a great city's life there is involved also the life of the country of which it is a part.

The only other local, as distinct from national, objects in the Stuart and Commonwealth Rooms are the two figures of cripples from St. Bartholomew's Hospital, and the fine portrait, by Janssen, of Sir George Whitmore. Not only charitable institutions like the hospitals possessed signs or emblematic figures. Shops, now and later, also exhibited them, the best known being the tobacconists' Scotchman: in the Basement are several such figures; one is illustrated below (see p. 2r9). As regards the portrait, Whitmore was a wealthy and vigorous citizen of London who in I63I was elected Lord Mayor, and in $\mathrm{r}^{6} 32$ knighted. He was a strong supporter of Charles I, and suffered imprisonment and loss in the king's cause. $\mathrm{He}$ was interested in the colonisation of Virginia. His house at Balmes or Baulmes, in Hoxton, appears to have been a well-known resort: it afterwards became a madhouse. Whitmore died in 1654 .

A document in the Stuart Room brings us to public affairs. The Museum is very fortunate in 
possessing the unique Tangye collection of Cromwellian papers, books, and prints. Sir Richard Tangye, who created this fine collection, was a self-made man who amassed a large fortune in the course of building up a great engineering business. He was born in I833, and died in I906. He was a constant benefactor to Birmingham, where his business was situated.

It is impossible here, of course, to deal with all the papers fully: that indeed would be a matter for a close detailed history of the period. Only a few will be mentioned specially now : and the first of these is a printed "benevolence," or request for an act of benevolence towards the king, which is in a case of Stuart and Cromwellian documents against the wall on the side of the room farthest from the window. In plain words (and the meaning of "benevolence" was perfectly well understood by Charles I and his subjects), this paper represents a forced loan of $f_{2} 20$ by a London citizen to Charles I. It was called an act of loyal grace, but was nothing of the kind. It was simply a fraudulent form of taxation. The City of London opposed Charles I persistently: he attempted to extort money from it in all kinds of ways, legal and illegal, and London resisted his attempts strenuously and not unsuccessfully. (Whitmore was an exception among the City officials.) Charles asked point blank for $£$ Ioo,00o as a loan: it was flatly refused. He issued all manner of patents and monopolies, at a price, thereby hindering the general 
bulk of trade : he levied ship money, but did nothing with it to put down the pirates of the Mediterranean, who ruined many a London merchant. He. imprisoned citizens who refused to pay: he dismissed the Parliament which would not vote him supplies. London, in fact, was genuinely harassed and even oppressed, so that men had to borrow to pay their rent, and trade was almost at a standstill. London, as we know, was not alone in England in resisting the king's unwise methods : it was, indeed, simply the leader in refusing to obey: The City trained bands were solemnly mustered, and fought against the king at Newbury in 1643 ; for which he set a ban upon London-ineffectually: he said that none should trade with London. A story, pointed if untrue, is told of James $I$, and of more than one English sovereign. The king, angry with the Londoners, threatened to remove to some other city the Parliament and the courts of justice. "Can your Majesty remove the Thames too?" asked the Londoners, knowing (as Celtic and Roman London knew) that no human power could take away that natural channel of prosperity. Neither could Charles I shut up and bar off the great port of the world.

The stirring events which led to the setting up of the Commonwealth need not be dealt with here. London had played a great part in opposing the king : it beheld the tragedy of his execution, that tragedy in which the gallant bearing of the victim went far to outweigh the culpable mistakes of his 
rule. The London Museum has a ghastly relic of the drama in Whitehall when Charles

"Nothing common did, nor mean,

Upon that memorable scene,

But laid his comely head

Down, as upon a bed."

It is a skull which is said to be that of the king's executioner, taken from his reputed grave in Whitechapel. It is in a case on the farther side of the Commonwealth Room. ${ }^{1}$

In this room also are the death mask and other relics of Charles's great successor, Oliver Cromwell, Lord Protector of England: one who, whatever his faults and mistakes, and however violent the means by which, under the force of circumstances, he reached the supreme power, must ever be held among the very greatest of Englishmen. It is curious, and suggestive, to notice how the portraits of Cromwell in this room differ. Sometimes the engraving is bad, sometimes the artist unskilful: one picture (in the farther window) is certainly a contemporary one: but, after all qualifications have been made, the likenesses show as many varieties as do the opinions of historians upon the man.

Cromwell's family Bible is here, and his private Bible, with his autograph: his watch also, and a button from his coat-possessions which bring his burning and tremendous personality very near to

${ }^{1}$ It is only right to say that the skull may not deserve this gloomy title to fame. It is probably that of Brandon, an executioner; but Brandon, it is very likely, did not execute Charles I. 
us. On the central screen, on the side nearest the entrance door, is a whole letter, written and signed by him, in his clear handwriting. In the same room is a contemporary bust of Charles I, perhaps the handsomest of English kings; and in the first case in the Stuart Room are medals to commemorate his death, and royalist badges. In the case between the windows, in the Stuart Room, is Cromwell's official inventory of the king's estates. So close does the London Museum draw us to the two chief figures in that sad struggle.

All the papers and prints are worthy of the closest

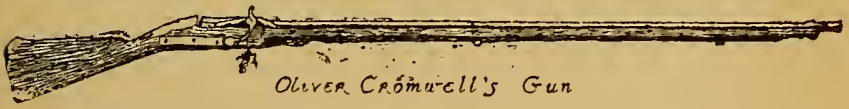

study. Here there is space to mention only two or three more exhibits. In the case at the end of the Cromwellian Room are documents of Richard Cromwell, the quiet, ineffectual second Lord Protector. Here, too, is the staff of office of the great Parliamentarian general, Fairfax, presented to him by Parliament on his appointment as Commander-inChief. On top of a case to the left is Cromwell's gun. A rent in the breech can be seen: but the gun has been greatly restored, and a good deal of it is really eighteenth century work. Nevertheless the strong hand of the Lord Protector must once have guided the weapon.

In the window of the Commonwealth Room is the autograph of General Monk (afterwards Lord Albemarle), which brings us almost to the Restora- 
tion, of which he was the principal agent. London had grown weary and distrustful of the Commonwealth and its system of government, though when Cromwell was first made Protector the citizens invited him " to a very splendid entertainment at Grocers' Hall, the streets being railed, and the solemnity of his reception such as had been at any time performed to the king ; and he, as like a king, graciously conferred the honour of knighthood upon the Lord Mayor at his departure."

There is one Londoner of the Commonwealth period who will never be forgotten-John Milton. He is not as yet represented by anything in the Museum, though he was born in London, and worked and lived most of his life there. London has a worthy memorial of him outside the church where he worshipped-St. Giles's, Cripplegate ; and in the basement of the Museum are pictures of many London houses with which he must have been familiar. It was in and of London that Milton wrote perhaps the noblest praise and the noblest ideals ever expressed of any city: "Behold now this vast city; a city of refuge, the mansion house of liberty, encompassed and surrounded with God's protection. ... What could a man require more from a nation so pliant and so prone to seek after knowledge? What wants there but wise and faithful labourers, to make a knowing people, a nation of prophets, of sages and of worthies? We reckon more than five months yet to harvest ; there need not be five weeks; had we but eyes to lift up, the fields are white already." 


\section{CHAPTER VIII}

THE LATE SEVENTEENTH CENTURY ROOM

The late Seventeenth Century Room, or Restoration Room, is a large and well-lighted chamber opening out of the previous apartment. It contains a collection of very varied interest. The period it illustrates was itself many coloured, and London begins now to seem almost a different place from the city which had fought so long for its ancient rights, and had seen within its walls so many changes, not only of families but of whole races. "Within its walls "-that is really a misleading phrase, a metaphor now, instead of a fact. The greatness of London lay henceforth outside the old City, at Whitehall, St. James's, and later even farther west. The King and the Court and the Parliament were to be the centre of London's world, instead of the Lord Mayor and Aldermen and the Court of Common Council. Under the later Stuarts London actually lost its constitution for a time-a thing which would have stirred even England deepiy a hundred years before; but now there was no rebellion, no vital interruption of trade. It was a question which concerned the City and its officials rather than the mass of Londoners, to whom it was perhaps not much more than a matter of excited gossip. In 
fact, the interesting feature of London henceforth is the picture it affords of English society, of which it was the focus.

The welcome given to Charles II on his return in 1760 shows that the occasion was national. $\mathrm{He}$ was met south of London Bridge by the Lord Mayor and Aldermen, and escorted through the city, the way being lined by the London trained bands (London's citizen army) and the liverymen of the great City companies. Innumerable gay banners were waving, drums and trumpets sounding, citizens cheering wildly: " there was never such a sight of noblemen and gentlemen that marched then, brandishing their swords all along." But the king did not stay in the City : he went right through it, without halting, to his palace at Whitehall; and in the evening it was not the City alone which rejoiced (with " almost as many bonfires in the streets as houses "), but London and Westminster. There was a new and greater London springing up.

The Museum contains at present no relic specially connected with the Restoration rejoicings. But in the case between the two windows on the right there is something to recall the end of the Stuart dynasty in England-a summons to the London trained bands to muster in 1688 , when London was in confusion through the flight of James I. The trained bands succeeded the old "Marching Watch" of the sixteenth century and earlier-a levy of all the freemen and apprentices of the City companies, once a year. The massed watch, numbering in I5I0 some 2000 men (thirty years later it reached 
I5,000) used to parade and march formally through the City. It became, however, little more than a show, and, as an armed force, was superseded by the trained bands, who, as has been seen, were mustered for ceremonial purposes like the Restoration procession as well as in real earnest for war against King Charles I.

The trained bands were the body of London citizens organised as soldiers. It was always the custom of the young men to practise archery and other military exercises, and Henry VIII in I537 gave the Guild of St. George (to-day the Honourable Artillery Company) a charter embodying its right to such practice. The Guild formed a nucleus of skilled men, who could in turn drill the trained bands, which at that period numbered about I5,000 men. A hundred years later there were about I7,000. In 1653 the trained bands all over England were dissolved-except those of London, which survived till I794, when they were developed into the London militia.

In this same case between the windows are some tokens which show how strong was the Stuart sense of the divine right of kings. They are "touch pieces." It was believed for many centuries that the touch of the king would cure the disease of scrofula, or "the king's evil." The practice of "touching for the evil" was begun by Edward the Confessor, and continued, so far as can be ascertained, by almost all the kings of England up to I688. Henry VII made a solemn ceremony of the custom, with a religious service and the bestowal 
of a token on the person touched. No English king after James II performed the rite ; but James and his son and grandson in exile continued to "touch," and struck silver coins for the ceremony. Evelyn has preserved an exact account of the first " touching " after the Restoration. It took place in I660. "His Majesty sitting under his state in the Banqueting House [Whitehall-the present United Service Museum], the surgeons cause the sick to be brought, or led, up to the throne, where they kneeling, the king strokes their faces or cheeks with both his hands at once, at which instant a chaplain in his formalities, says, "He put his hands upon them, and he healed them.' This is said to every one in particular. When they have all been touched, they come up again in the same order, and the other chaplain, kneeling, and having angel gold [the touchpieces] strung on white ribbon on his arm, delivers them one by one to his Majesty, who puts them about the necks of the touched as they pass, while the first chaplain repeats, "That is the true light who came into the world.' Then follows an Epistle (as at first a Gospel) with the Liturgy, prayers for the sick, with some alteration; lastly the blessing; and then the Lord Chamberlain and the Comptroller of the Household bring a basin, ewer, and towel, for his Majesty to wash."

The window case contains also a long folding print of the Coronation of James II : sheets of this kind, which are issued on similar occasions to-day, show that printing, whether from engraved plates or from type, had become a much more practic- 
able, easy and widespread art. The reign of James II, indeed, saw the first English newspapers of note.

There is also here a lease from the New River Company. It has been said already that London owed much of its water-supply to the generosity of private merchants, who at their own expense laid down pipes or conduits for the public use: Lamb's Conduit Street, for instance, off Red Lion Square, near Holborn, commemorates one such gift by William Lambe, a rich clothworker of Elizabeth's reign. But under James $\mathrm{I}$, in $\mathrm{I} 6 \mathrm{I} 2-\mathrm{I} 3$, a much more important undertaking was carried out by Sir Hugh Myddelton, a London merchant, who caused the New River to be cut from near Ware to Islington-a great canal bringing water, so to speak, to the doors of London. It still supplies a large part of London's water, and shares in it are very valuable.

Other objects in the case are some miniatures, sleeve links, a pathetic little heart-shaped lovetoken, a hunting-knife, a tobacco-box, and a locket containing a piece of the hair of Queen Mary (consort of William III). These are more or less domestic things, and we may turn from the window case to the window nearest the door, and see kindred objects-some magnificent samplers, full of the most minute work, and a leather trunk brightly studded with a pattern in nails. In two cases on the other side of the entrance door are another instalment of the Museum's great collection of spoons ; an old sundial; a mazer or wide, shallow drinking 
bowl of wood-a kind of cup which had been in existence for some four hundred years; a metal mortar cast in Whitechapel in I668-at a famous bell foundry which has continued in exactly the same place of business to this very day; some more pipes and pipe stoppers; and horse-bells. On a screen close by is a document, half-domestic, halfpublic. It is an order, dated 1673 , for six horsemen to convey a sum of money from Lewes, in Sussex, to the Exchequer, for the king's use. Charles II was often in need of money, and this order illustrates both that trait in his curiously interesting character, and the realities of finance in his day. There were no postal orders, and very few facilities for cashing drafts upon persons at a distance: the money had to be carried, in actual coin, by special messengers. Hence it was profitable for highwaymen to plunder travellers and coaches, because persons going from place to place had to carry about with them much larger sums of money than to-day, to last out their needs till their return home. It is a sign of the increase of travel in England itself, and the necessity for better communications, that the first public postal service (other than that which carried the king's despatches) was established in the reign of Charles I, in I635; indeed, the first penny postal service was not much later, for a certain William Docwra for a short time-until he was stopped for infringing the State's monopoly in the posts-instituted a penny service for Londoners. In Charles I's reign the post-coaches from London to the provinces 
covered fifty or sixty miles a day, and the mounted postmen twice as far. An ordinary letter was carried eighty miles for twopence. ${ }^{1}$

In the central case in the room, there is much beautiful glass. Burial in the ground has increased its beauty by giving it rainbow colours. There are some fine pewter dishes and tankards-pewter ware was common and good during this period; a pipe case, which with the tobacco-box mentioned above is one of the earliest indications of pipes having been carried about, instead of being kept in private houses or taverns; a barber's bowlperhaps a bowl for blood, for barbers were then surgeons as well, and bleeding was the chief remedy for many complaints-not at all a bad remedy in an age of fevers and apoplexy ; and some bone skates, which bring us to the Frost Fair on the Thames in I684.

It need not be supposed, from this and other Frost Fairs, that the English climate has changed greatly. We are looking back not over the lifetime of one Londoner only, but over many generations : whenever there was a hard frost, men made special note of it, so that it seems more important and more frequent than it really was. And the fact that the Thames was frozen over, for reasons already mentioned, makes the frost appear to us now even more tremendous. As a matter of fact, it needed little larger frost then to cover the Thames with solid ice than is required now to cover Highgate

1 See The Post Office: an Historical Summary. Published by order of the Postmaster-General, I9I I. 
Ponds. Three weeks of continuous frost meant a Frost Fair ; and three weeks of frost still occur at intervals - at least three times, for instance, in the last thirty years. So that Restoration London was really not more Arctic than the London of George V.

In the Basement of theMuseum are three specimens of bills printed on the frozen Thames: one is dated I684, one I739-40, one I8I4. On each occasion much the same scene was witnessed: booths were set up, for the sale of food, drink, and commemorative trifles. There were entertainments of various kinds ; royal personages visited the fair, and sheep were roasted whole. In $\mathrm{I}_{8} \mathrm{I}_{4}$ the main walk, from Blackfriars Bridge to London Bridge, was a continuous line of traders' stalls: it was called City Road. There are many prints of this last fair (see p. 227).

The ice on the Thames itself, as it consisted to a great extent of larger blocks from farther up the river (the remains of a previous thaw, or the beginnings of the frost), was rough, though there were smooth places. It was possible to skate upon it here and there. But skating on metal runners was comparatively strange to Englishmen in Charles II's reign. It was called sliding, and John Evelyn, the diarist, speaks of it with interest and surprise, as if it were a new thing : he first saw it in 1662 :

"Having seen the strange and wonderful dexterity of the sliders on the new canal in St. James's Park, performed before their Majesties by divers gentlemen and others with skates, after the manner 
of the Hollanders, with what swiftness they pass, how suddenly they stop in full career upon the ice; I went home by water, but not without exceeding difficulty, the Thames being frozen, great flakes of ice encompassing our boat."

Skates before this time were just bones tied to the foot: this is one of them. The new fashion of using metal skates was learnt by the refugee cavaliers in Holland during the Commonwealth.

Not far from the Frost Fair prints in the Basement are other seventeenth century exhibits. One is in a glass case under the first window in the long room filled with prints of the London Parks. It consists of the mallets and ball of the game of Pall Mall-an early species of croquet, which came to England from France in the seventeenth century, and became very popular at the Restoration. It was played on a special ground in the fields which are now the famous street of Pall Mall. Pepys describes the "pitch" as being covered with " cockle shells powdered and spread, to keep it fast, which, however, in dry weather, turns to dust and deads the balls." It was the fashionable open-air game for Londoners of Charles II's court ; and it is partly to the fashion of walking in the parks in the neighbourhood of St. James's Palace and "Pall Mall" that we owe the public parks of that district to-day. Charles II loved to walk there with his favourites, his little dogs, feeding the waterfowl with which he had stocked the lake; and it was he who made the land into a public park for ever. Many of the birds on the lake in St. James's Park are the 
direct descendants of the very birds he placed there. We shall return to the parks for a moment when we go through the Basement for the last time.

The other seventeenth century object is a little farther on in the Basement. It is a child's rocking horse, worn and faded, but still a gallant enchanted courser of the right grey breed. The stirrups, it is true, are only wooden foot-rests, and the brave beast

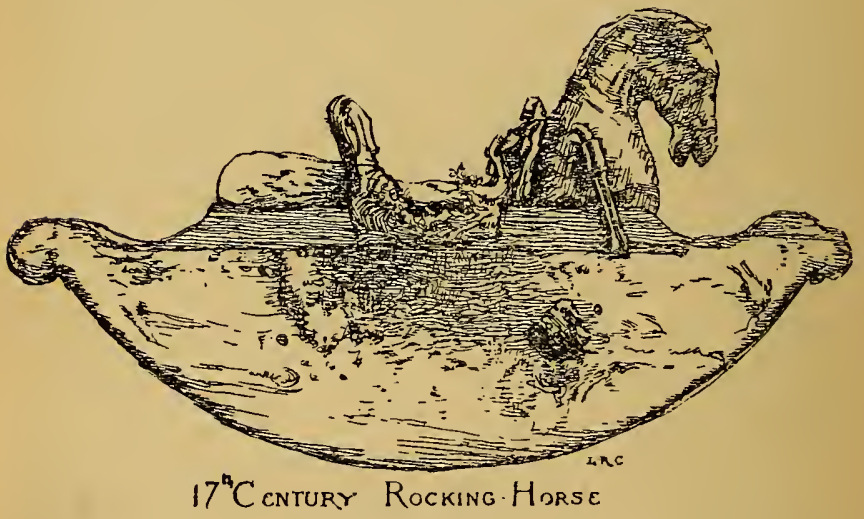

has no visible legs, but curvets upon a solid round base. Yet he has borne many a child to fairyland, and galloped along the high road of nursery adventure with a faithful simplicity, in far-off ages when real life knew no such simple joys.

And so back to the upper floor to King Charles the Second's London, where, in the case in the angle of the left-hand walls, are grim realities. Many fires and many plagues had London experienced before, as has been said, but never such a fire or so 
great a plague as those of 1665 and 1666 . It was fortunate for the health of the City that the Fire came after the Plague.

The Plague relics here shown are a bell, fuming pots, ointment pots, and a drug jar. London, in the summer of $166_{5}$, was a city of the dead. On every other door were the terrible red crosses that showed infection, or the bills with " Lord have mercy upon us." In every street bellmen tolled dismally, crying, "Bring out your dead." Death carts, laden with bodies, rolled noisily over the cobbled pavements, the empty street redoubling the hollow sound with echoes. "Now," says a contemporary writer, "Death rides triumphantly on his pale horse through our streets, and breathes into every house almost, where any inhabitants are to be found. . . . Now shops are shut in, people rare and very few that walk about, insomuch that the grass begins to spring up in some places, and a deep silence almost in every place, especially within the walls; no rattling coaches, no prancing horses, no calling in customers, nor offering wares; no London cries sounding in the ears: if any voice be heard, it is the groans of dying persons, breathing forth their last, and the funeral knells of them that are ready to be carried to their graves. . . . Now the nights are too short to bury the dead; the long summer days are spent from morning until the twilight in conveying the vast number of dead bodies unto the bed of their graves."

The story is too well known to need further repetition. It can be read in the form of vivid fiction in 
Harrison Ainsworth's Old St. Paul's or Defoe's Journal of the Plague Year. It left a deep mark upon the life of London and the memory of her citizens, and even to read of it two and a half centuries later stirs a feeling of pity and awe.

Not less terrifying was the Fire, which broke out on the night of September I, I666, and lasted till September 7. The Museum possesses a fire helmet of the period (see illustration), a torchholder, and a cresset, or holder for balls of flaming material, such as was borne by constables appointed for the purpose : it is easy to guess from such things how readily a fire might arise in the narrow streets, with their wooden buildings and lack of good extinguishing appliances. The objects in the glass case are the charred and calcined remains found on the site of the burnt houses.

The area devastated stretched from the Monument, by London Bridge, to Giltspur Street, where Holborn and Newgate Street meet. Pepys, looking on it from Southwark, saw it " as one entire arch of fire from this to the other side of the bridge, and in a bow up the hill for an arch above a mile long." All who could do so moved the chief part of their goods to the outer suburbs : the rest looked on in fear and wonder, or lent a hand to pull down houses in the line of the fire's probable advancethe only real remedy they could think of. The King and the Duke of York (afterwards James II) visited the scene, and gave whatever orders were possible to stop the disaster: Charles II showed not a little of the real ability he so seldom chose to exert. 


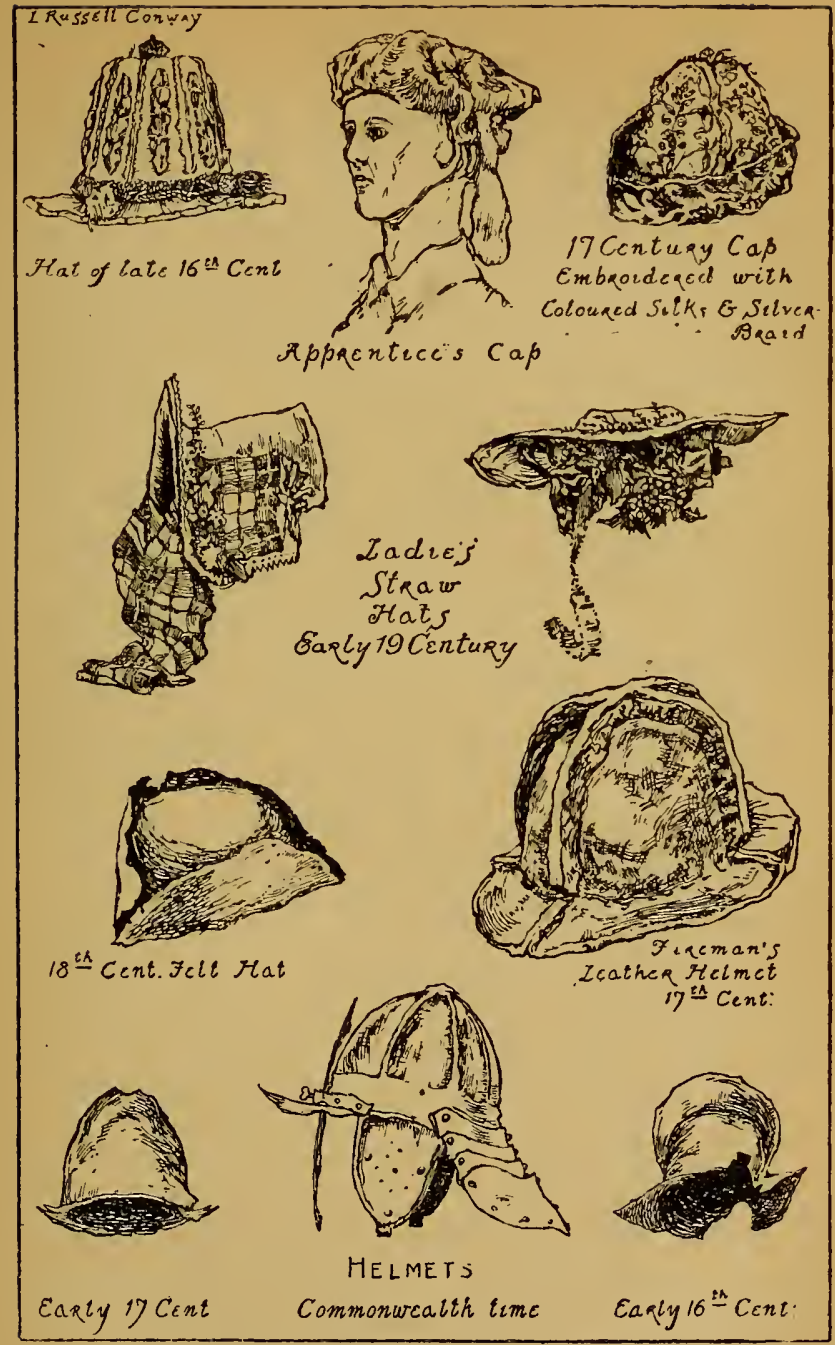

Hats and Helmets of Four Centuries 

There was a magnificent chance after the Fire to rebuild London with a breadth of outlook worthy of its greatness. Wren and Evelyn submitted plans to the King which would have given a noble setting to the new St. Paul's that was to arise through Wren's genius. The King approved them heartily : he could form ideals, if he never lived up to them. But jealousies and smaller interests stood in the way of a real reform; and though the old dangerous squalor was not renewed, St. Paul's Cathedral alone-after a display of incredible meanness towards the architect-was made worthy of the London that was to be.

It may be mentioned here, perhaps, that Evelyn, who loved London with a serious devotion, found one of the chief drawbacks to it a nuisance which no multitude of complaints has to this day contrived to abate to any appreciable extentthe smoke of London's chimneys. He wrote a work upon the subject, complaining bitterly of the "clouds of smoke and sulphur, so full of stink and darkness": he attributed them largely to the growing use of coal instead of wood as fuel.

The case on the right of the Plague relics contains some miscellaneous objects : a facsimile of a great silver-gilt cup, the original of which belongs to the Merchant Taylors' Company; some Dutch tiles; William III's watch, and a watch by Tompion (see p. $15^{8}$ ); a glass goblet made in commemoration of the Coronation of William III and Mary; and wax-relief busts of those sovereigns. James II had given recognition to this art by inviting a famous 
French modeller, Benoist, to England. But before we reach the Restoration of 1688 there are two other features to be considered-the two models of ships, and the cases of china at the end of the room.

The two ships are fully rigged men-of-war of James II's period, bearing the "Jack" of the period (the Union Jack without St. Patrick's cross) and the Royal Standard. The larger one is a 92gun three-master. The label states that James II was the founder of the British Navy. He had every opportunity of founding it. Under Cromwell, the fleet, commanded by Blake, had made England respected alike in European and West Indian waters : other nations feared the power of the Protector. Under Charles II the Navy reached the depth of degradation. In 1667 the Dutch sailed up the Thames to Chatham, entered the Medway, burnt the ill-equipped, helpless men-ofwar there, and took the Royal Charles, in which Charles II had returned to England. Pepys tells us what London thought of it: "people make nothing of talking treason in the streets openly." There were proposals to sink ships in the Thames at Woolwich and Barking to stop any further advance by the Dutch. The City was terrified: " the alarm was so great," says Evelyn, "that it put both country and city into a panic, fear and consternation, such as I hope I shall never see more : everybody was flying, none knew why or whither. ... A dreadful spectacle as England ever saw, and a dishonour never to be wiped out." Someone had to be blamed; and the disgrace was fastened upon 
Pett, the then head of the celebrated Chatham shipbuilding family. But the real culprit was Charles II, whose personal extravagance had deprived the navy of money. The sailors were unpaid, and the ships unfurnished. James II, ably helped by Mr. Secretary Pepys-whose great talents as an administrator would not easily be guessed from his famous diary-brought about a better state of things. He had, during his brother's reign, stoutly resisted the parsimony which led to the Chatham disaster; and when he came to the throne, he appointed a commission which examined thoroughly and impartially the affairs of the navy, and created a formidable fleet. The chief feature of these two models of ships may seem to-day to be the beauty of their lines, the delicate strength and grace of their whole appearance. But their real value in the Museum is to recall the time when, because our sea power had been left to decay, London, with all its wealth and its immense interests, was at the mercy of an invader.

Last of all we come to the pottery of this period. It is in several cases on the farther side of the room from the entrance. The cases in the large bay window are filled chiefly with Lambeth delft ware : nearer the exit door are specimens of the handiwork of John Dwight, of Fulham. We have arrived at the beginnings of the great English pottery industry, which to-day we so easily take for granted. When you have a cup of tea, even in the humblest tea-shop, you are indebted to John Dwight and his fellow-workers in London under the Stuarts. 
Before their time there was no such white glazed ware made in England.

Pottery and china, as has been said, are in principle very simple products. It is in practice that the difficulties and developments arise. But it is now time to define them a little more exactly, or else the succeeding rooms of the Museum will have little meaning. Broadly speaking, all the wares covered by either term fall into two main divisions -(i) earthenware, and (ii) porcelain. Now earthenware, in its plainest form, it has been pointed out, is just earth moulded and baked, and it is not necessary here to go into the technical differences in methods of production. The next stage was to apply to the rough earthenware a finer and thinner paste or glaze, and fix it by baking again. The Celts, as we have seen, made plain earthenware. The Romans glazed their best ware. In the chaos that followed Rome's fall, the art of glazing vanished from England for a time: but it gradually came back, and we have seen specimens of it in the Tudor and Stuart Rooms. Glazing means, simply, giving the ware a shiny surface-covering it with a sort of very thin glass: the glaze might be coloured, of course.

As soon as the art of glazing began to be well understood once more, earthenware grew more varied, and from the seventeenth century onwards it is divided into classes according to its most characteristic feature. The green glaze was a very elementary form of ornament. The next to it in simplicity, perhaps, is what is known as slip 
ware : this consists of (as always) an earthenware body, coated with a thin paste of different colours, which was dried, glazed, and then baked. Delft ware, on the other hand, has a more highly refined body, and a white surface, and the glaze is obtained from tin. Dwight or Fulham ware will be dealt with in a moment. Salt glaze ware is ware glazed by the use of salt: it produces a very hard glaze. Other earthenwares were named after their makers, like Elers and Wedgwood ware. In fact, all the different kinds of earthenware are different because, first of all, the earth itself is mixed more or less finely, so that the body colour varies, and secondly and chiefly, because the slip and glaze applied to it is also varied in fineness and in colour. There is really no difference in essence : the difference is in proportions and in chemical action.

Stoneware really comes almost half-way between earthenware and porcelain, as will be seen when we deal with John Dwight : it is, however, for purposes of classification, earthenware. China or porcelain, on the other hand, is, properly speaking, the ware made from a very pure clay, called, in fact, china clay: the main quality of all porcelain is that it is translucent-nearly transparent, so that, for instance, one's fingers show faintly through it. It is not necessary here to go into the details of manufacture. All that need be done, as we are drawing near a very fine collection of English china, is to say that it is, for all practical purposes, an eighteenth century product in Europe. Until in rjog Böttger discovered the secret of handling china 
clay in the Chinese manner, and the great Dresden wares began to be produced, China alone could make real porcelain. Englishmen did not master the art to any great extent until the London workers at Chelsea and Bow, in the middle of the eighteenth century, began to supply the fashionable world with their fine wares.

But in the Restoration Room we are still only in the earthenware period. The porcelain has been mentioned here simply for clearness, to show the gradual spread and development of the potter's art in England. Up to the Restoration, as the previous rooms have shown us, England had not succeeded in doing more than making quite simple earthenware with a quite simple glaze fired on to it. Why, then, was there this outbreak of white and other coloured ware in the seventeenth century? The names-china and delft-give the clue to an answer. For centuries past the Chinese had had their knowledge of the art of mixing glazes and moulding the finest "china" clay. It was the Dutch merchants of the Far East who made the Chinese wares well known in Holland and Europe generally; and the Dutch and German potters began at once, with more or less success, to copy the gleaming whites and clear blues of real "china" -but as yet with earthenware as a basis. Work of this kind began to be produced at Delft, in Holland, about 1600 -we have seen an imported piece in the Tudor Room (p. 88). It is not certain when it was first made in England, but it was probably produced in Lambeth by Dutch settlers in London. A famous patent granted to J. A. van Hamme, of 
Lambeth, in 1671 , for making "tiles after the way practised in Holland," is a landmark in the history of English pottery. Thereafter "delft" wareusually neither so fine nor so well made as the original Dutch-was made in great quantities in many parts of England. But it is to London, and to Lambeth in particular, that the foundation of the industry in this country is due. The chief feature of delft is the white enamel upon the earthenware : it takes blue and other colours admirably.

The Venus dish in the central window case is a typical piece of a well-known pattern. There is a fine set of wine bottles : they were used for table purposes, being filled from the cask. The fuddling cups, the use of which has already been explained, are near relatives of the bottles: and perhaps the fever of intemperance might be allayed by bleeding -barber's bleeding bowls of delft ware are shown here too. All the pieces in these cases deserve close attention: they show the way in which the English potters tried, successfully or not, as the case might be, to obtain always a purer and clearer colour. Even when the bluish or reddish tinge is too suffused and widespread, the bowls and dishes and bottles are still an immense advance upon the brown and green ware of earlier periods.

John Dwight, of Fulham, to whom the case nearer the door is given up, was perhaps the greatest of all English potters, though it may be that the later fame of Wedgwood has overshadowed him. He was born in I637, was an M.A. of Christ Church, Oxford, and died at Fulham in 1703 . He obtained patents for his wares in I67I and I684: 
they stated that "by his own industry and at his own proper costs and charges, he hath invented and set up at Fulham, in our county of Middlesex, several new manufactures of earthenware." $\mathrm{He}$ claimed that he had discovered the secrets of Cologne (i.e. of German stoneware), and of Persian porcelain : but he took very good care to keep most of his own secrets. He was for ever making experiments, as though out of an ardent curiosity and love of the work : he hid or destroyed, however, moulds, tools, and notebooks dealing with those of his wares which were unsuccessful or unprofitable.

Pieces of Dwight's ware are now very uncommon, and the London Museum is fortunate to possess even this little hoard. Compare these figures even with the best of the delft-with, for example, the portraits of Charles II on the caudle cups of Lambeth delft. The latter is the work of a craftsman, but not of an artist. Dwight's productions were the work of both; and if, as seems probable, he was his own designer and modeller, he must have been a very remarkable man indeed. As regards his claim to have made both German and Persian ware, it does not seem to be accurate, unless, indeed, as might be the case with so whimsical a genius, he hid or destroyed his "Persian " products irretrievably. What was most like porcelain was his stoneware, which is a very fine kind of earthenware. When it was glazed-if it was, and if its polish is not the natural effect of baking-it had a salt glaze applied, which produced a hard, gleaming brown surface. Dwight was also able to use many colours, but the specimens here shown are typical of his work. 
That, then, is one great benefit the Restoration period conferred upon London-it founded the pottery industry, and adorned daily life with its beautiful wares. Though the chief English potteries now for the most part lie far away from London, it was London which gave them birth. In the next three rooms we shall see how London enjoyed its own productions.

In the case nearest the exit door, on the right hand of it, there are other objects of some interest, though they do not need comment. One is a lantern clock-a clock, that is, shaped like a lantern, with ornamental openwork. This was a favourite seventeenth century pattern. Clocks of a private kind, so to speak, were not common in England at all till late in the sixteenth century. During that period also watches became more or less popular, and before long they were made in England instead of being imported from Germany. The most famous of all English clock- and watch-makers, Tompion, lived from I638 to I7I3 (see p. I58).

Another object in this case is a large white and blue dish, with some strange figures of an owl and a cat and a monkey upon it. It is a squib of the day-a humorous attack upon certain new fashions - the rail and the top knot. It belongs to the last year when a Stuart was sovereign in EnglandI688, when James II, perhaps the ablest, and certainly the most unstatesmanlike of his interesting dynasty, waited in Whitehall for an easterly "Protestant" wind to bring William of Orange past the navy which James had created, and which, 
by a bitter irony, preferred the new dynasty to his. So we are introduced by two suggestions-fashions and a memorable date - to the eighteenth century rooms, and to that world of elegance and taste and complacency which its delightful literature can make so real to us.

On the walls high up over the exit door are two groups of weapons. Especially notable are the crossbows, in this century superseded, for good and all, by the long musket, which was rested upon a forked staff and let off by means of lighted tinder -far enough from the rifle of to-day, but equally distant, in efficiency, from the old bow and arrow.

It was under the Stuarts that London began to grow a little like the London we know. West London, the West End, sprang up rapidly: no longer was Piccadilly in the country and Westminster a place apart. That unending succession of brick which is now London began to be consolidated on all sides. Clerkenwell, Bermondsey, Newington Butts, Mayfair (most of the Piccadilly great houses arose in this period), St. James's (diversified by parks) became nearly continuous with the City. The City itself was more like what we call now the City - the place of business. The life of London itself began at Temple Bar and ran to the parks and palaces, the theatres and gardens and coffee-houses of Whitehall, St. James's, Drury Lane, Covent Garden (laid out as a great square or piazza under Charles I), and Westminster. 


\section{CHAPTER IX}

THE JOICEY AND OTHER COLLECTIONS OF CHINA

THE last five rooms on the first floor of the Museum tend to overlap one another slightly. They contain, in order (i) the Joicey collection of china (with a few other notable pieces, and some miscellaneous objects)-this fills two rooms ; (ii) a further collection of china and pottery, with some exhibits illustrating social life in various ways-assembled in "the Late Eighteenth and Early Nineteenth Century Room "; (iii) two fine collections of costumes ; (iv) a small case of theatrical exhibits ; and (v) costumes of the Regency and Victorian periods, ending in the Coronation robes of King George V. For the purposes of this book, it will be convenient to group the first two rooms together, and consider them as representing the eighteenth century, or most of it: the third room will be treated as covering the period from about I800 to 1837 ; the Costume Room demands separate treatment; and the Victorian era, with the theatrical collection, will make a fourth chapter to end the suite. As the Basement also, apart from the exhibits in it which have already been mentioned, is chiefly filled with relics of the eighteenth and nineteenth centuries, it too should, strictly speaking, be treated in these chapters. But its contents, with a few exceptions, are 
largely architectural or topographical, and so form a complete subject in themselves, capable of the separate treatment which they receive in the last chapter of this book.

We come, then, to the Joicey collection of English china or porcelain; and a very fine collection it is. Mr. Joicey has been a generous benefactor to the London Museum, and the gift of this collection is an invaluable one, for the cases in these two rooms show us the life of the eighteenth century from many different angles. The Joicey treasures are supplemented by some very fine pieces lent by Mrs. Salting, the widow of the great collector, whose magnificent bequests have enriched the National Gallery and the Victoria and Albert Museum so splendidly.

The first case on the left of the first room contains "Battersea enamels." The name itself is important. The wares were made in London, and were enamelled-not merely glazed, or merely decorated with a pattern of thin paste. They are, in fact, porcelain or very fine earthenware painted or printed with an enamel design. York House, Battersea, was a noted place for such work : it became famous for it about I750, having been founded, perhaps, a little before that date, by Stephen Janssen. China factories elsewhere in London occasionally had their designs painted at Battersea.

Whether the supply of such wares created the demand for them, or whether the demand for them sprang from interest in the similar and even more perfect French enamels of the day, and so created an English source of supply, it would be difficult 
to say. But the objects in this case show very clearly what sort of people made the demand. They are all connected with luxury or adornment of life-with a state of society which evidently called for elegance and gaiety and "fashionable" manners. Cane-tops, scent-flagons, needle-cases, snuff-boxes, patch-boxes-they are the belongings of people to whom polite intercourse and entertainment was the chief joy of life. That is one aspect of the eighteenth century in London.

The next case on the left contains humbler things -slip ware, in the form of bowls, porringers, fuddlingcups and the like: the objects of daily use among people who lived robustly and coarsely. Slip ware was, so to speak, the china of the poor in the eighteenth century. It was the cheap, natural, strong, native product which slender purses and unfashionable tastes could afford to buy. It is earthenware, not porcelain, as has been said already (see p. I38).

Look next, for a comment on this slip ware, at certain pictures on the walls in the next roomoriginal drawings by Thomas Rowlandson, and a print of Hogarth's "Southwark Fair." Rowlandson was one of the greatest draughtsmen among English artists, though he often allowed his skill to be used for the wildest, ugliest and coarsest sort of caricature. Hogarth, "the first. great English painter," as he has been called, portrayed and satirised all sides of English life in the eighteenth century. He was a stern and faithful moralist as well as a great artist, and his pictures are often depressing because of the debased side of existence 
which they reveal. If the eighteenth centuryhad contained nothing but the events shown in "The Rake's Progress," it would have left a black mark upon English history: but there was another side to it.

These pictures are the counterpart of the slip ware, to a certain extent: they stand for low life in London under Queen Anne and the Georges-a life that was often brutal, boisterous, drunken, and dirty, and yet brave and strong in its squalor. In the Basement we shall see more of it.

Next to the case of slip ware is one of Chelsea ware, of the period from I745 to I769. On the right hand of the room is another case of this ware, and in the next room still more cases. Except one or two special pieces, the objects can hardly be described in full detail here. A short account of the Chelsea works, which produced the finest of all English porcelain, will enable the visitor to form his own judgments. .

The earliest known piece of Chelsea ware is dated I745: the factory may have been in existencefor some years before that. It is said to have been supported by the Duke of Cumberland : the two first managers were Frenchmen-Charles Gouyn and Nicholas Sprimont. The works were in Lawrence Street, Chelsea : a few traces still survive in the cellars of a house there-a great arched kiln, and evidence of a passage below the house level ; and little broken pieces of the old wares are still picked up when the garden of the house is dug.

Sprimont had been a silversmith, and as he "furnished or oversaw the models of all that 
was made at the works," he must have been a man of remarkable talent, both artistically and practically. His management made the Chelsea wares famous all over Europe: the best examples are unsurpassed for beauty and perfect workmanship. The London Museum is the proud possessor -or depository, for the object is only on loan-of perhaps the finest piece of Chelsea china in existence-one of the finest pieces of china of any kind, indeed. It is the celebrated "Dancing Lesson," or "group within a boscage," lent by Mrs. Salting. It stands in a case at the end of the second and larger China Room, on the right of the exit door. A shepherd and shepherdess, of the wonderful French Court type, are seated in a boscage-a shelter of most minutely wrought branches and leaves and flowers. All round are flowers of a delicacy and artificiality suited to the shepherd and shepherdess. The shepherd plays a musical instrument, the shepherdess nurses a dog fantastically dressed, which she is trying to induce to dance: two other dogs are prancing on the ground on their hind legs. Only one other specimen of this group is known to have been preserved. It is in perfect condition. It has been reproduced on a very striking poster of the Underground Railway.

The whole scene of the group is typical of the period, of an age which had rediscovered what it was pleased to call Nature : nature, that is, "to advantage dressed," not allowed to retain its crude wildness. English polite taste was modelled on that of France, where the court of Louis XIV. 
at the end of the seventeenth century, had fallen in love with mock simplicity. Fairy tales, for instance, came into favour: told, probably, by

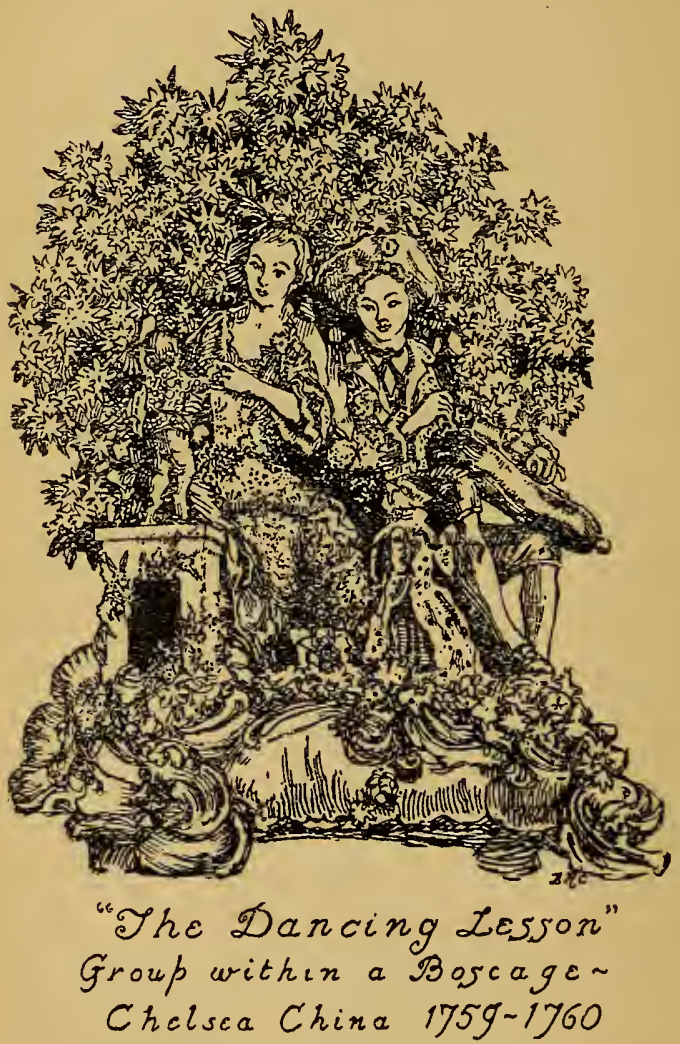

an old country nurse to M. Perrault's little son, the Tales of Mother Goose, as Perrault wrote them, set a fashion among the wits and beauties, 
and everyone was for dressing as a fairy, or a peasant, or a shepherd. Poets wrote and artists painted nothing but scenes of rustic elegance, of country innocence and peace, of courtly ways set in groves and gardens and charming woods. The uncomfortable side of country life was forgotten. There were no wasps or spiders, no rain, no burning sun, no work to be done willy-nilly, in such a boscage as this which the French artist Roubillac designed for the Chelsea china works: nothing but a reasonable amount of sunshine (tempered by a pleasant shade from "day's detested glare "), docile animals, the silver sound of streams, birds singing discreetly and not too loudly, and fine raiment and pretty speeches for the happy children of nature.

Another point to be noticed in this superb piece of china is the view it gives of performing animals and pets. The eighteenth century fashionable lady had invariably a lapdog, or a monkey, or a parrot. And the "animal comedians" were one of the chief sights at Vauxhall Gardens, as will be shown when we reach the Basement.

So this pretty fantasy in porcelain is not so artificial or so remote from real life as it might seem. Once it was part of the airs and graces of a graceful age-a thing which Lady Betty Modish might believe the last word in high fashion, or upon which even the stupid Sir Plume,

"Of amber snuff-box justly vain, And the nice conduct of a clouded cane, With earnest eyes and round, unthinking face," 
might turn a light compliment. These Chelsea scent-flagons, cane-heads, and snuff-boxes must have been borne by men of whom the groups and ornamental figures, gleaming new, were no bad likeness: from these Battersea patch-boxes many a lady of quality must have taken a patch for her smooth cheek, the better to resemble her model in porcelain fresh from the kilns of Lawrence Street. The wealth and variety of the Chelsea figures is extraordinary: harlequins, sheep, Chinamen, frogs, famous actors in noted parts, hens with their brood, Cupid in a hundred postures, trees, dogs, rabbits, dancers-there is no end to the charming "toys." The output of the factory was enormous. Its activity in London lasted some thirty years or so, of which the last four or five produced the finest work. The British Museum Guide divides the ware conveniently into classes; the first consists of ware mainly white or creamy white: the second of objects "thickly made ... . and often decorated with oriental patterns." The third period is from $I 75^{\circ}$ to $I 758$, when Sprimont was most active. In the fourth, from I759 to I770, French influence is very marked. In I769, apparently, Sprimont resigned through ill-health : the works were sold to a Mr. Cox, who, in I770, resold them to William Duesbury, whom we shall mention again shortly. Duesbury carried on the works for fourteen years, and then removed them to Derby, where for many years "Chelsea-Derby" ware was produced. That was the end of the great Chelsea china industry so far as London is concerned. 
On the right hand of the Joicey Room is a case of Bow china, and there are other specimens in the succeeding room. The Bow factory, like that at Chelsea, was the direct outcome of the interest in Chinese porcelain, and of the successful attempts in Germany and France to produce these delicate wares. Bow china, perhaps, shows its origin even more closely than Chelsea, for the decorations are often the little blue flowers and branches which appear on the best Eastern china : and the works were called New Canton. It is not quite certain when the factory was opened ; but it was in existence in I744, when Edward Heyleyn and Thomas Foy took out a patent for making porcelain after a recipe of their own, which was specified as depending largely upon "an earth, the produce of the Cherokee nation in America, called by the natives unaker." The noble red man was to furnish gay ornaments for the nymphs and swains of Vauxhall and Ranelagh Gardens. The output of the Bow works was enormous for that time: in I754, for instance, the worth of the sales amounted to over eighteen thousand pounds. The pieces are as a rule less fine than those of Chelsea, but they are, at their best, of a high standard. The history of the factory is much the same as that of the Chelsea works. It flourished exceedingly for a time, but gradually declined in public favour, till, in I 762 , the sole survivor of the then partners, John Crowther, went bankrupt. He continued in business, however, and was finally bought out in 1775 by William Duesbury, who, the next year, re- 
moved the manufacture to Derby, to be joined by the Chelsea products later and be merged at last in the all-conquering Derby ware.

Derby china is no direct concern of the London Museum, except in so far as it was sent to London for the use of Londoners-as it was, in great quantities. It evidently was popular enough to supersede, gradually, the London wares of Chelsea and Bow, when the splendid artistic and practical vigour of the first workers had begun to fade a little. In fact, William Duesbury formed something very like a "trust" in the best china. He had had a business of his own in London for a few years: he made enamels from I75I to I753, and presumably thus became acquainted with china-workers who came to him to have their wares ornamented. In I756 he apparently started china works at Derby, in association with a financier (to use the modern term)-John Heath, a banker-and an inventor or artist, a French refugee, Andrew Planché : Duesbury, whatever his other qualifications, was obviously the business man, the promoter, of the concern. John Heath had owned already, among other property, a pottery at Derby, and he too probably knew a good investment when he saw it. So the Derby works were set up, and like Aaron's rod, swallowed the opposition.

That is all that is relevant in the story of Derby china, and not much more need be said now about the splendid specimens of Bow and Chelsea ware and Battersea enamel shown in these two rooms. They are important for three reasons. First of all, 
anything beautiful, anything to which the loving skill of true artists has been dedicated, is important to us to-day-important as a model of form or execution, and important as a relic of the hope and sincerity and toil of men of our flesh and blood. Secondly, these specimens stand for an industry which brought wealth and interest to London. And lastly, they are a mirror of the life of Londoners. They were not only objects of daily use in the fashionable world : they were objects of ardent thought. The satirists and essayists were always finding matter for ridicule in the devotion of ladies of quality to the frail ware of China. (China, by the way-the China of gardens and architecture and manners and porcelain and silk and tea-was a subject of deep attention all through the eighteenth century.) One writer, for instance, invents a mocking story of how "a famous virtuoso lady" bought a fine "mandarin and a joss" for her Chinese temple, the envy of all her friends: "but the brutish waggoner happening to overturn his carriage, they were crushed to pieces ": the shock was so great that she lost her reason, and her cell at the Bethlehem Hospital is described as decorated with "Chelsea urns, which she believes to be the true Nankin."

That is satire; but, as we have seen, and as we shall see again, the eighteenth century did take its adornments and its pleasures very earnestly: good taste was the breath of life, though, by a seeming contradiction, a certain amount of eccentricity might be considered good taste. "England," 
says an essayist, " affords a greater variety of characters than the rest of the world." But if you would be eccentric, you must let your eccentricity emphasize the prevailing good taste rather than criticise it-you must use an extreme of fashion, not a parody of it.

There are other articles of fashion in these rooms. The central cases in each contain clocks, watches, snuff-boxes; and trinkets. As most of the clocks and watches of the Museum are here, it is advisable to say something of them in general at this point. Why should they be so plentiful during this period?

Clocks are older than watches, which require more delicate and experienced workmanship. The early clocks were worked by an arrangement of weights, which, by falling, set wheels in motion : probably they were in use from the twelfth century onwards. The wonderful old church clocks still to be seen in various parts of England-at Wells Cathedral, for instance, where at the hours two figures of mounted knights rush forth and tilt violently against one another, or at Wimborne Minster, where the sun solemnly crawls round the earth in a model of the solar system-are worked in this way. Obviously, they require so much room that they could only be set up in large buildings; and it was not till the invention of the mainspring - a fine spring of steel which, by gradually uncurling until it is wound tight again, keeps the system of wheels in motion-that clocks of a smaller size were possible. A clockmaker of Nuremberg, Peter 
Henlein or Hele (I480-I542), probably made this invention for the first time.

But there is another device, which seems at first sight very mysterious, before the watch or clock can "go "-whether it is worked by weights, or by pendulum (which is a weight in another form), or by a spring-and that is what is called the escapement. Weight and pendulum really involve just the unrolling of a reel : the mainspring means the loosening of a pent-up force. If a weight dropped, it would drop (by a law of gravity) so many velos -so many feet per second in an increasing ratio : it would accelerate. If a pendulum swung unregulated, it would gradually slow down. If a spring uncurled without a check, it would uncurl more vigorously at first, when it is tight, than when it has become slack. True time, in fact, would not be kept if these devices were left to themselves. The escapement is at once a brake and a higher gear, to use the modern term. It is a contrivance (of two projecting flanges and many more complicated arrangements), which acts upon the bar moved by the spring, weight, or pendulum, so as to hold its work back at one moment, and assist it the next. It gives the automatic movement, in short, a check in the one direction and a push in the other, so that it is equalised. The uneven working of the mainspring is further checked by a device called the fusee, invented by Jacob Zech, about I525. But the escapement is what, in all watches and clocks, harmonises the various movements. 
The sixteenth century, then, was the period in which watches were first made with some perfection. The art of making them reached England slowly, just as other arts did-that of making porcelain, for example. The first English-born watchmaker was Bartholomew Newsum, who had a shop in the Strand in I568. Naturally, however, it was some time before so highly skilled a trade could be provided with many craftsmen, and the great age of English watchmaking did not really begin till the seventeenth century, since when English watches have been held in very high repute. The Clockmakers' Company was incorporated by charter in I63I : its collection of clocks and watches is shown in the Guildhall Museum.

The greatest of all English watchmakers was Thomas Tompion (I638-r7I3), a specimen of whose work is in the Restoration Room near the exit door, on the left. His shop, at the sign of the Dial and Three Crowns, was where the Daily News office now stands in Fleet Street. He made many improvements in the machinery of timekeepers, and his watches and clocks were noted for their accuracy. He was buried in Westminster Abbey, and his partner and successor, George Graham, was afterwards laid to rest in the same grave. The epitaph records that his "curious inventions do honour to the British genius, his accurate performances are the standard of mechanic skill."

The snuff-box was a habit and a ritual in itself : tobacco, either for pipes or as snuff, was a feature of coffee-house life, and it was the most elementary 
mark of politeness and recognition to offer a pinch of snuff from your elegantly finished box. The variety of snuff-boxes was endless: they show in their workmanship every fine handicraft of the day, and in their shape, ornament, and inscriptions, every fashion. A mock advertisement (yet not far from the truth) of I III runs :

"The Exercise of the Snuff-Box, according to the most fashionable Airs and Motions, in opposition to the Exercise of the Fan, will be Taught with the best plain or perfumed Snuff, at Charles Lillie's, Perfumer, at the Corner of Beaufort Buildings in the Strand, and Attendance given for the Benefit of the young Merchants about the Exchange for two Hours every Day at Noon, except Saturdays, at a Toyshop near Garraway's Coffee-House. There will be likewise Taught the Ceremony of the Snuff-Box, or Rules for offering Snuff according to the Degrees of Familiarity or Distance ; with an Explanation of the Careless, the Scornful, the Politic, and the Surly Pinch, and the Gestures proper to each of them."

(Garraway's was a famous City coffee-house, which lasted even till the days of Mr. Pickwick; Garraway is said to have invented our " national " dish " eggs and bacon." A toy-shop meant a shop where these Chelsea and Bow "toys" or trifles were sold.)

The jewellery of the period, so far as it appears here, was not very striking. A great poem of the time explains, in a few lines of imaginary history, the fate of many ornaments of gold and silver. It describes a bodkin or hair-pin of Queen Anne's day, 
one belonging to a person of rank, "Belinda," Mrs. Arabella Fermor :

"The same, his ancient personage to deck, Her great-great-grandsire wore about his neck In three seal rings; which, after, melted down, Formed a vast buckle for his widow's gown. Her infant grand-dame's whistle next it grew ; The bells she jingled, and the whistle blew. Then, in a bodkin, graced her mother's hairs ; Which long she wore, and now Belinda wears."

But the eighteenth century contained not only low life and fashionable life. Look at the grave "grandfather" clock in the Joicey Room, and go into the next room, and see the heavy, pompous chiming clock, with a mill scene and little figures, "all made to work," on the left hand. Then walk down the middle of this large room, on the window side, to a central case near the far end. It contains a perfect example of Georgian domestic life -a fine doll's house of I740, all complete, with parlour, drawing-room, kitchen, large bedroom, two bedrooms on the top floor, and two basement rooms. Lady dolls preside over this little world : how real a world to how many generations of children can but be imagined. Here is the quiet life of the day: the life of decency and fixed opinions, without extravagance, of gravity and peace without pomp. The age of George II, of which so little is heard but of its follies or its miseries, must have known many such a sober, pretty, complacent home as this, where a tall clock would tick away the unchanging minutes year after year, and its 
companion with the striking apparatus sound the hours with a solemnity unbroken and unvarying for little things and great alike.

There are probably a good many dolls' houses of the eighteenth century still in existence; but

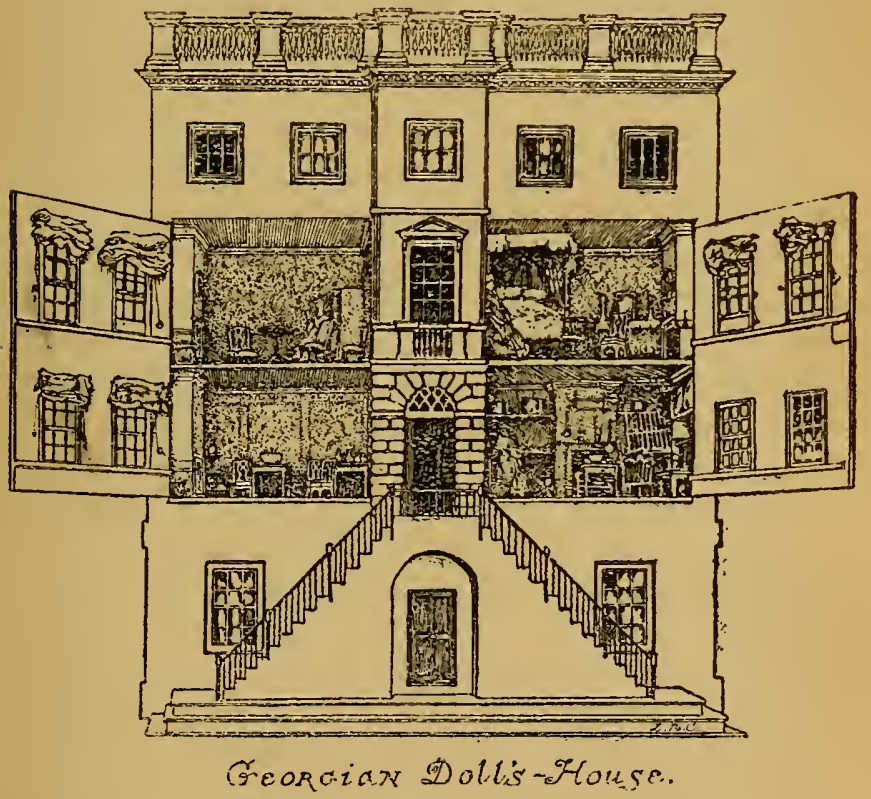

there are few older. Mrs. Neville Jackson, in Toys of Other Days, only enumerates eight, the earliest of which was made in $155^{8}$.

Dolls themselves are the oldest of all toys : they have been found in remains of the ancient Egyptian civilisation, and Greek and Roman children used them two thousand or more years ago. Almost 
equally old are the materials still used - rag, pottery or china, and wax : india-rubber, of course, does not appear before the nineteenth century, and early in that century, too, the device for opening and shutting the eyes seems to have been invented. The first "talking" doll, which said "Papa " and "Mamma," is ascribed to I824.

The young City bloods, as the advertisement already quoted shows, were ready enough to imitate the ways of their social betters. But they would often have to do it secretly, for apprentices were still under severe legal control of their masters. Even the son of a merchant, if he were apprenticed to his father, might have to sleep under the counter and tend the shop. The merchants themselves were men of substance. Addison said of his creation, Sir Andrew Freeport, "there is not a point in the compass but blows home a ship in which he is an owner" : and he was delighted to see at the Royal Exchange "so rich an assembly of countrymen and foreigners consulting together upon the private business of mankind, and making this metropolis a kind of emporium for the whole earth.' There is a case in the larger room (in the middle of the room) which suggests the civic pride of the day : it contains armorial china of the City Companies, whose wealth now was growing rapidly, as their trade spread over the widening world, and property in the City increased in value. The pieces are not particularly beautiful, nor very interesting in themselves; but they show the City's readiness to take advantage of the best china productions. 
The life of London, indeed, had changed utterly since the Commonwealth. Her citizens began to be no longer Londoners, but citizens of the world -Englishmen who lived, by the accident of geography, in the great fair or market-place of mankind. It is true that in this century London showed its old spirit more than once: especially when it stoutly supported Middlesex's persistent return to Parliament of John Wilkes. It is true also that the commerce of the place expanded amazingly, as the rapidly widening world sent ever more varied and richer wares up the London river. It is true also that one of the greatest of Londoners is of this epoch-Samuel Johnson. But the character of the town was altered : its pride now was not in its rights and privileges so much as in its claim to lead the fashion of England in art, and letters, and social usages. That is the significance of the Costume Room, which we shall reach presently: it is the significance also of these gracious china wares.

A picture, on the left hand, of Pope's "grotto" at Twickenham suggests that leadership in fashion. Pope, that genius, whose life, from disease, was "one long agony," was, next to Addison, the head of English literature in the first half of the eighteenth century: he both inspired and followed the standard of elegant taste. His grotto, like Horace Walpole's house at Strawberry Hill later, was a storehouse of the curiosities and "toys," valuable and worthless alike, in which the age delighted: and here the wits debated with him the prose and 
poetry, the history and philosophy, all the topics of interest of an epoch never surpassed in alertness and critical excitement.

In a window on the right hand is the bust of a rival poet, James Thomson. He brought back into English literature a little of that love of the real country (not the well-arranged, artificial country of Pope) which earlier ages had felt so keenly, and which was to be deepened and broadened so gloriously by Wordsworth at the end of the century. Thomson could look out from a formal eighteenth century room and see not only arbours and neat walks and pretty gardens, but that larger vision of

"Gay castles in the clouds that pass, For ever flushing in a summer sky."

It is a sign of London's position that now Pope and Thomson, Addison and Swift, Defoe and Prior must all write in London and all win their fame from the approval of Londoners.

There are many other pictures in these rooms. The chief, perhaps, are those of Covent Gardenwithout the market-house, but with the colonnade and the church front: of Hyde Park Corner, with the toll-houses-the beginning of London on the west; and of the first Westminster Bridge, opened in $175^{\circ}$, and rebuilt between 1854 and I 860 .

There is also in the middle of the second room a very fine model of the church of St. Martin's-inthe-Fields, the masterpiece of the architect Gibbs, and one of the most typical and attractive of 
London's churches. It was built in I72I-26. In the churchyard lie buried Nell Gwynne and Roubillac, the designer of the "group within a boscage ": he settled in England as a young man, and carved many public monuments in London. 


\section{CHAPTER X}

THE LATE EIGHTEENTH AND NINETEENTH CENTURY ROOM

A MAP of London in $\mathrm{I}_{8} \mathrm{I}_{4}$ lies open beside the paper on which this book is being written. Its colours are faded to soft blues and drabs, but its clean copper-engraving is as sharp and clear as ever, and it shows how small, even a hundred years ago, was the town that now stretches east and west, almost unbrokenly, from Ealing to Ilford-fifteen miles. In the year when Napoleon was sent to Elba its uttermost limits from east to west were from Paddington to Stepney Green-hardly more than half the former distance. Beyond those limits were fields and villages such as to-day even the longest motor omnibus journey barely reaches. There were turnpike gates on all sides shutting off the traffic until dues for the upkeep of the roads had been paid : a famous one stood at Hyde Park Corner (the previous room contains a picture of it, as has been montioned), and another about where the Marble Arch now is islanded. There were but three bridges in this London proper-London Bridge, Blackfriars Bridge (at first called New Bridge-the approach is still named New Bridge 166 
Street), and Westminster Bridge. Waterloo Bridge (which also was to have been called New Bridge) was planned, but not yet made. To the southbeyond a line drawn from Kennington to Rotherhithe-and east were open fields. Fields separated Ranelagh Gardens, in Chelsea, from Mayfair and Westminster : fields were where now the squares of Belgravia and Pimlico stand in their regiments. To the north were fields, rising to the tree-clad heights of Hampstead and Highgate; and where now the dismal streets of Pentonville and Clerkenwell shut out all green, Londoners of $\mathrm{I}^{8} \mathrm{I} 4$ took their pleasure in yet other fields-the famous Spa Fields, where taverns and gardens maintained the practice of selling the medicinal waters of the numerous springs. Of these pleasure resorts we shall see more in the prints in the Basement.

The main streets ran in very much their present line. The stretch between Oxford Street and Holborn, however-now New Oxford Street-took a large curve to the south, along the line of the present Broad Street (W.C.) and High Street. Holborn Viaduct was Holborn Hill and Snow Hilla steep valley, in the bottom of which was the river Fleet. There was no Shaftesbury Avenue, no Charing Cross Road, no Kingsway, no Trafalgar Square, no Victoria Street, no Embankment, no railway stations. The streets were almost all narrower, the houses less lofty than these of to-daybut often more beautiful.

It is of that smaller, more compact London that many objects in the Late Eighteenth and Nine- 
teenth Century Room (we may call it more shortly the Regency Room, though, of course, it covers a larger period than the Regency) reminds us. The case against the wall on the left hand contains relics of some very famous buildings. There is a fine tea-caddy, for instance, in the form of Old Carlton House. Carlton House stood formerly at the bottom of Lower Regent Street, in Pall Mall. It was built early in the eighteenth century, and pulled down in I826 : its columns are now part of the portico of the National Gallery. It was chiefly notable for its association with the Prince Regent, afterwards George IV : it came into the possession of the royal family in I732, and George III also used it for social functions. Perhaps the most celebrated of all the entertainments given there was that in honour of the Prince of Wales' appointment to the Regency, in I8II. George IV was always lavish in his public and private expenditure, but on this occasion he exceeded all bounds. There were over two thousand guests (including the exiled French royal family), and the festivities cost, it is said, $£ I 5,000$. Six tons of gold and silver plate were used, and the house was a mass of heavy gilt and ormolu decorations and crimson satin. This was an age of display rather than of taste, and seldom can there have been a greater parade of luxury and solid wealth. The supper-table of the Prince was decorated very wonderfully, and, according to a contemporary account, "exhibited a grandeur beyond description." In front of the royal seat was "a circular basin of water, with an enriched 
temple in the centre of it, from whence there was a meandering stream to the bottom of the table, bordered with green banks. Three or four fantastic bridges were thrown over it, one of them with a small tower upon it, which gave the little stream a picturesque appearance. It contained also a number of gold and silver fish."

The general public were admitted to view the decorations during the following week, with the result that on the last day of such admission the crowd was so great that many visitors were seriously injured : others had their clothes so seriously torn that they had to send for fresh garments before they could go home ; while the odd shoes picked up afterwards " filled a large tub."

It was an age of exuberant entertainments and high living. One of the most notorious figures in it was the Marquis of Hertford-the supposed original of Lord Steyne in Thackeray's Vanity Fair : a great noble and a bad man. His dressing-case is here.

Here also are things that bring back the vanished older London-London of the merchant princes and the proud, indomitable civic spirit. There is a piece of the timber of the famous cobwebless roof of Westminster Hall-of the oak that only in I9I4 has needed help in its old age. Westminster Hall, one of the greatest glories of London and of England, was built originally by William Rufus, and parts of that old foundation still remain. But the present building was completed in the last year of the reign of Richard II (I399); and in that 
very year the unhappy king was forced to abdicate in the hall he had so nobly built:

"With mine own hands I give away my crown, With mine own tongue deny my sacred state, With mine own breath release all duty's rites: All pomp and majesty I do forswear."

Here the law of England built up its stately precedents and learned procedure, for in this Hall the Courts sat for near five hundred years. Here Cromwell was made Lord Protector of England, here Thomas More condemned, Anne Boleyn tried, the Seven Bishops acquitted; here all the eloquence of England pleaded for or against Warren Hastings. No spot in the world, save Westminster Abbey itself, is more deeply wrought into the fabric of English life : the glorious roof has echoed to every great cry in our history.

The Hall has been restored from time to time; but in essence it is as it was when King Richard laid down his majesty in it.

The Royal Exchange of Gresham we know already (see p. 98): here is a box made from a fragment of the oak left when it was burnt down in I838. Here, too, is a box made from the piles of Old London Bridge, that had stood for well-nigh seven hundred years. The last houses left upon the Bridge had been removed in $1757-8$, not long before George III came to the throne: the new bridge was opened by William IV. And in this case, too, is a snuff-box made of the roof-timber of the old Guildhall. The present Guildhall is a hybrid build- 
ing. The fine porch is part of the second Hall, built in I4II : it is not known when the still older building which stood here before that was built. Most of the rest of the Hall, the least beautiful part of it, was erected in 1789 . The whole was restored in 1870 . This little piece of wood must have helped to shelter the Lord Mayor and Sheriff and citizens century by century : under it Lady Jane Grey was tried : under it the men of London resolved to stand up against King Charles.

Newer London is to be seen on this wall, too, in an odd fashion. There is a group of the relics of the building of the Thames Embankment-forgeries, made to sell to those who expected great finds of antiquities during that huge undertaking. It seems strange that London had to wait so long to control the Thames: the Embankment was only opened in 1870 . Wren had planned it in his scheme for rebuilding the City after the Great Fire : but, as we have seen, little came of that scheme. It was left to a great engineer of the Victorian era, Sir Joseph Bazalgette (to whom a relief monument has been erected by Charing Cross Railway Bridge), to set up this immense river wall, and, incidentally, to reorganise the drainage of London.

Of the great Queen herself, in whose reign so much of the London we know took on its present form, the first of the many relics possessed by the Museum is here exhibited: it is the writing-case she used when she was only Princess Victoria-that simple girl whose modesty and strength of character so 
soon impressed her ministers when, still young, she was called to the throne.

This room, indeed, is a mirror of varied and rather mixed life. In the case on the left of the door, for instance, is a collection of later Fulham stoneware-flasks, "pocket pistols" (flasks in pistol shape), jugs in the likeness of faces or people (of Queen Victoria, for instance): the simple native humour of London, through many centuries a constant feature in the character of its citizens, breaks out once more in these well-finished but homely vessels. Equally homely are the Staffordshire figures in the corresponding case against the opposite wall. There is something oddly pleasant about these queer likenesses of the great and good, with their fine rich blues and their shining black hair. Here are Queen Victoria again-this time with baby princes to look after and a British lion to guard her-and Spurgeon (the famous preacher), and many other celebrities. This, unlike the Fulham vase, is a kind of porcelain, not earthenware ; and so, very often, is Isleworth ware, of which specimens are in the same case. "Staffordshire" is a general name for the work of many potters : potters worked in the county from time immenorial. The white "delft" manufacture was introduced there, apparently, early in the eighteenth century ; but it was a development yet newer than the use of china clay which really gave Staffordshire the chief place in the pottery industry -the adoption of bone-ash as the foundation of the porcelain. Late in the eighteenth cen- 
tury this material began to be employed, and it is still the chief substance of the wares of everyday use. In figures like these, English pottery, having first learnt the lesson of finer manufacture from abroad, expressed the blunt, unsophisticated, yet on the whole, kindly joviality of the race. The Isleworth works were established in the last half of the eighteenth century and lasted till I \& Io : earthenware was made there also.

In the left-hand wall-case, too, is a hint of the literary life and the commercial life of the dayone of the prize pens annually awarded at Christ's Hospital: the school was then and always famous for its penmanship, and there Charles Lamb learnt that delicate, neat handwriting that is so full of character. There, too, doubtless, many a lesser person learnt the "copperplate hand" which the merchants of the day demanded of their clerks. Good writing was a milestone on the road to success, as Nicholas Nickleby found: "Nicholas dipped his pen into the inkstand before him, and plunged into the books of Cheeryble Brothers. Tim Linkinwater turned pale, and tilting up his stool on the two legs nearest Nicholas, looked over his shoulder in breathless anxiety ...' He has done it !' said Tim, looking round at his employers and shaking his head triumphantly. 'His capital B's and D's are exactly like mine; he dots all his small $i$ 's and crosses every $t$ as he writes it. There ain't such a young man as this in all London,' said Tim, clapping Nicholas on the back-' not one.' " And so to affluence. 
The cases on the right hand of the room illustrate social life more minutely than it is possible to describe here. If we knew the full story of all the routs and balls, all the ceremonies and formalities that these visiting cards and invitations record, we should have a picture of human vanity and hope and disappointment and joy, that it would take a lifetime to examine in detail. Let one exhibit suffice to imply the elaborate pomp and parade of emotion of the day-the pictures of funeral mutes above the case nearest the door. No grandeur that could by any artifice be compassed was omitted from the barbaric show of public sorrow on such occasions: grief was thought to be measured by the amount of money spent on gloomy and mournful emblems.

Apart from the cards and notices, the objects in these two cases are, on the whole, connected with individual persons of eminence, or public displays, or the buildings of London. There is a card belonging to the first Duke of Wellington; a little sketch by Queen Victoria-a by no means incapable artist, as another exhibit later shows; medals and seals commemorating public events and the opening or foundation of buildings; a foundation plate of Hammersmith Bridge (the first suspension bridge over the Thames, opened in I827); medals struck in honour of the visit of the Emperor of the French to the City in I855; a letter of Nelson; a cheque signed by the writer who has been called "London's special correspondent for posterity," Charles Dickens; a vue optique, or folding telescopic view 
of the Thames Tunnel, built between I824 and I843-when the view is opened out, it becomes a kind of peepshow, inspected through the holes in the front: and a season ticket for the Exhibition of $185 \mathrm{I}$. That was the first of the great international exhibitions of which England hoped so much. The Crystal Palace was erected for the occasion, in Hyde Park, about where now the Albert Memorial stands: there are prints of the scene in the Basement. The Queen herself opened the Exhibition, and all London marvelled at the palace of glass which Sir Joseph Paxton had set up. It was rebuilt at Sydenham in 1884 , and in I9I3-I4 purchased for the nation by public subscription. Londoners have, perhaps, lost faith, to-day, alike in exhibitions and in the Crystal Palace; but in $185 \mathrm{I}$ the brotherhood of man and the worldwide supremacy of British trade both seemed to be proclaimed by the dazzling "greenhouse" in Hyde Park.

There are many pictures round the room which are worthy of study by those interested in the exact changes in the streets of London. Perhaps the most suggestive to us to-day is one above the case on the farther wall, on the right hand-a painting of an old horse omnibus, with the "knifeboard" seat on top of it. The story of the London omnibus is one of those byways of history which will for many years to come wake recollections, and perhaps regrets, in the minds of Londoners. It is not ten years since the 'bus-driver was a London institution, and his pair of fine horses a wonder and 
delight. The streets rang with the sound of hoofs instead of the grinding of changing gears. To-day not one regular service of horse 'buses runs in the City. The drivers had a steady outlook and a philosophy of life which, if it was sometimes rough and crude, was also human and above all Cockney -and no Londoner need be ashamed of being a Cockney, if such a thing exists now. Wonderful stories were current of the wit and repartee of rival drivers of the old 'buses : though, if the truth must be told, they were often neither very ready nor very witty. The writer remembers but two from personal experience, each the result of a race between drivers. Two 'buses drew up abreast at the Bank crossing, after desperate efforts by each to secure the lead all along Cornhill. One driver became rather abusive : the other made no reply, but remained in silent contemplation of the opposition horses : at length he answered. "Pore things!" he said, solemnly regarding the other's horses with profound sympathy : "pore things!" And that ended the controversy.

The other retort was of the direct personal kind in which Cockneys have often excelled. A purplefaced driver, with an inordinate nose, was being taunted by a rival, whose face was large and flabby and also provided with plenty of nose, of a pale fleshiness. Red-face endured the insults in a silent fury for some time, but at last found speech. "My nose may be red," he said hoarsely, "but it ain't made of putty, and it ain't spread all over my face." 
They are gone now, the drivers and the horses: never again will Mr. Punch be sure of a subject for a picture in the strife between old ladies and the "cad," as the early conductors were called. To some extent the South African War destroyed the vitality of the horse omnibus: too many of the gallant beasts went out, like the Londoners themselves, to take their share in the war, as members of artillery teams; and few came back. But that was an evil which time would have cured. The real danger was, of course, the motor omnibus with the petrol engine-a much more convenient vehicle, it must be admitted, if less picturesque, and organised in a service a thousand times more efficient.

Omnibuses-a plural which shocked persons of precise speech, when it was first used, almost as much as did the mock suggestion of an alternative, "omnibi "-were a French invention. The name is attributed to a grocer of Nantes, named Omnès, who set up as his sign a Latin pun-Omnès omnibus, "All for all." The owner of some baths saw the sign, and borrowed the "omnibus" part of it, for a vehicle he ran for the use of his customers. From this it was transferred to the public vehicles which, in I8I9, Jacques Laffitte started in Paris. Laffitte gave an order for "omnibuses" to Shillibeer, a coach-builder of London and Paris, who, struck by the convenient design, adopted it, and began a similar service of vehicles in London. The first to run started from the "Yorkshire Stingo" Tavern, at Paddington, on July 4, I829, and travelled to and from the Bank. Seventy years later 
the first modern motor omnibus traversed the streets of London. It is, perhaps, worthy of record that the first vehicle to cross Holborn Viaduct when it was"opened in 1869 was a "City Atlas" horse omnibus.

Shillibeer died in 1866 . He had revolutionised London traffic. Omnibuses were for a long time called shillibeers; but as, before his death, the owner of the name became an undertaker, and a hearse was also liable to be called a shillibeer, the term quickly disappeared.

Motor omnibuses, it should be said, are not a modern invention, though the petrol engine is. In the Basement there are several pictures of "horseless carriages" of the period from I830 to I840 : the best known was Mr. Goldsworthy Gurney's, which ran many hundreds of miles and carried a large number of passengers. But the great cost of working, the jealousy of coach and omnibus proprietors, and the very heavy turnpike dues prevented these unwieldy engines from becoming a financial success; and so the motor omnibus disappeared till the twentieth century. ${ }^{1}$

We shall have to go backwards and forward over the years in the last chapters of this book, beholding permanence and change side by side from generation to generation. There is one thing that remained continuous throughout the eighteenth and nineteenth centuries-the throne. In

1 For fuller details see Mr. H. C. Moore's very interesting work, Omnibuses and Cabs, upon which the above account is largely based. 
the case against the left-hand wall is a dumb chronicle of English history-medals struck for every coronation from James I to George V. Here are the likenesses of that Stuart dynasty which twice had to learn that England, like London, is a good subject when it has a good master. Here is William III, that serious, able Dutchman, and Queen Anne, who "sometimes counsel took and sometimes tea"; unpopular George I and II ; "Farmer" George III, whose life ended so pitifully; and George IV, the "first gentleman in Europe," the "fat friend" of the bloods and dandies: the sailor William IV, in whose reign England was nearer revolution than at any time since $I 688$; Victoria, whose long reign strengthened the monarchy immeasurably; and her son and grandson, in whose time it has been said that the sovereign of England is "a king among free men, and a free man among kings." 


\section{CHAPTER XI}

THE COSTUME GALLERY

The Regency Room opens into the largest room on the first floor of Lancaster House, the splendid apartment in which are arranged three fine collections of costume-the Joicey collection, given by the same benefactor whose treasures are to be seen in so many other rooms of the Museum ; the Abbey collection, presented by Mrs. Abbey in memory of her husband; and the Seymour Lucas collection, presented by the collector, who happily is still living. Mr. E. A. Abbey was an American by birth, but he lived much in England, and worked there ; his historical paintings and wall decorations are to be seen in many buildings in England and America. He died in I9I3. Mr. Lucas is the wellknown painter of historical and "subject " pictures and an authority on costume.

The costumes shown are very varied, and as they are arranged in groups according to their donors, it is impossible to consider them in strict chronological order. It will be best to mention first a few striking exhibits of special and individual interest, and then to give a brief history of the garments as they arise-men's dress, women's, hats, shoes, gloves, umbrellas, hair-modes, orna- 
ments and small articles of various kinds. There are also some specimens of weapons of different sorts, and at the far end of the room a "Georgian dinner-party" group, which will round off our survey, made in the last three rooms, of indoor life in the eighteenth century and a little later.

To begin with the specially notable exhibits. In a case in the middle of the room, almost opposite the entrance door, but a little towards the right, are the oldest complete costumes in the Museum. For obvious reasons, it is unusual to find garments intact three hundred or more years after they were worn: but here are two fine complete suits of an Elizabethan noble. In just such raiment as this the great Englishmen of the spacious days paid court to the Virgin Queen, or sailed cheerfully to "singe the King of Spain's beard," or went to look on, perhaps a little contemptuously, at the people's theatre set up by Burbage and Shakespeare on Bankside in Southwark. The men who wore these trunk-hose and doublets may have heard Elizabeth's brave words to the sailors of London as they set forth against the Armada- "I have the body but of a weak and feeble woman, but I have the heart of a king, and of a King of England, too "; or they may have died the cruel death of the day for the sake of their faith : or they may just have lived the quiet life of sober Englishmen, remote from strife and tumult.

In the case against the wall on the right hand of the door are two more relics of warlike days -a uniform worn at the battle of Waterloo, and a 


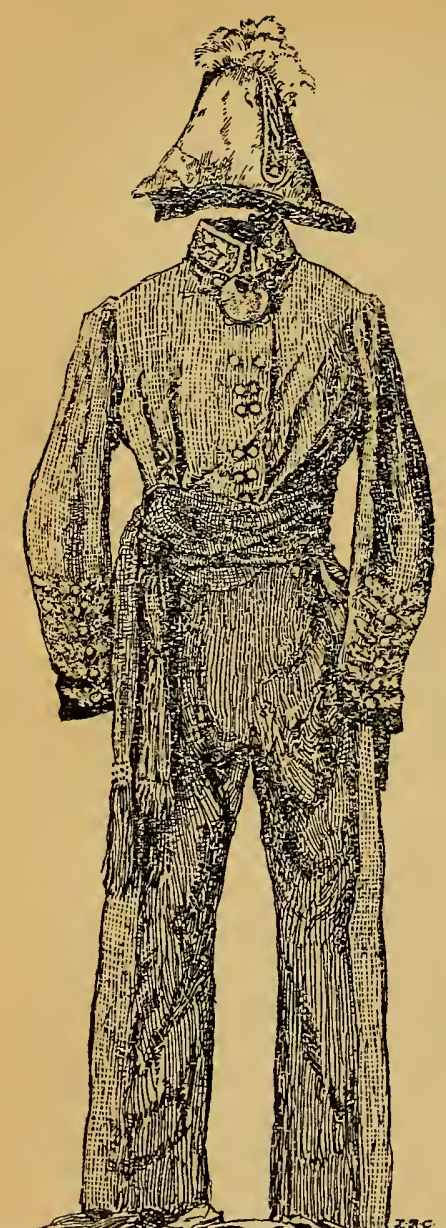

-

OFFICER'S UNIFORM WORN AT THE BATTLE OF WATERLOO panel from the trappings of a horse in the funeral procession of the Iron Duke who won that battle. We think idly of the victory ; we can realise a little the horrors of a fight that was, for all practical purposes, hand to hand, and imagine something of what it meant to Europe to have the terror of Napoleon taken away at last and for ever: we can glory in the unbreakable courage of the British soldier. But there is more in a battle than that: more that, if it could speak, a uniform like this could tell. There is no nobler passage in English literature, none truer to the facts of life and death, than those chapters by Thackeray that describe Brussels before and after Waterloo. Here is such a scene as that red sash may have 
seen: "Amelia was wrapped in a white morning dress, her hair falling on her shoulders, and her large eyes fixed and without light. By way of helping on the preparations for the departure [to the front] and showing that she too could be useful at a moment so critical, this poor soul had taken up a sash of George's from the drawers wherein it lay, and followed him to and fro with the sash in her hand,

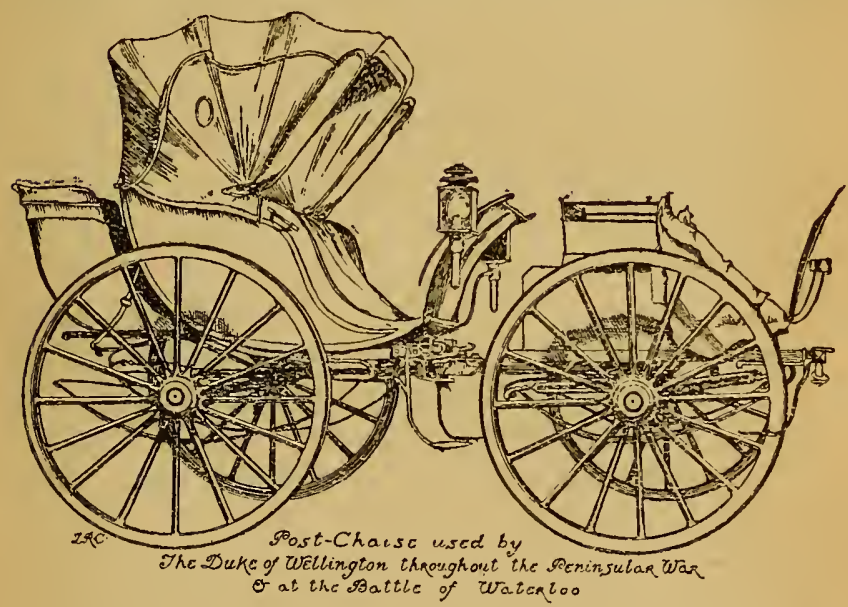

looking on mutely as his packing proceeded. She came out and stood, leaning at the wall, holding this sash against her bosom, from which the heavy net of crimson dropped like a large stain of blood."

In the Basement is a relic which deserves mention here-the post-chaise which Wellington used throughout the Peninsular War and at Waterloo itself. The Iron Duke, even with this aid, must indeed have been made of iron to go through those 
years of incessant fighting with no faltering in his great abilities. Officers and men alike in his wars were spared no more than himself : they showed a physical endurance not surpassed even in Elizabeth's day.

Another battle is represented among the costumes. In a case on the same wall, but some way down on the left of the entrance door-part of the Seymour Lucas collection-is the uniform of an officer of the Irish Dragoons, killed at the Battle of Dettingen ( $\mathrm{x} 743$ ). There is both reality and history there : Dettingen was the last battle at which an English king (George II) took the field in person.

There is a more peaceful interest in the sedan chairs, one of which stands on each side of the room, a little way from the entrance. A sedan chair explains itself : it was a box large enough for one person, seated : the side, and sometimes the top, opened, and it was carried by two porters or chairmen, walking between shafts at either end, which they held in their hands as a wheelbarrow's handles are held. The chair was introduced into England in the reign of Charles I, and it died out in the first half of the nineteenth century. Hackney coachesthe forerunners of cabs-had very nearly the same period of existence. The cabriolet (introduced in I805: a kind of gig with the door at the side-Mrs. Raddle visited Mrs. Bardell in one), the hansom (patented by Joseph Hansom in I835), the "growler," or four-wheeled cab, or "Clarence" (of which the brougham is an adaptation: it was introduced in the 'forties), and the omnibus (see p. I77), all 
combined to make the sedan chair obsolete. But for two centuries it had shared with the hackney coach the public traffic of London. Chairs were cabs, so to speak : they could be hired at a recognised uniform fare. The chairmen had no great reputation for civility: but they had grievances of their own, as a mock-advertisement of the eighteenth century shows: "I am a Chairman. You know, sir, we come when we are called, and are expected to carry all who require our assistance. It is common for men of the most unwieldy corpulence to crowd themselves into a chair, and demand to be carried for a shilling as far as an airy young lady, whom we scarcely feel upon our poles. Sure, we ought to be paid, like all other mortals, in proportion to our labours. Engines should be fixed in proper places to weigh chairs as they weigh waggons; and those whom ease and plenty have made unable to carry themselves, should give part of their superfluities to those who carry them."

In a case on the left hand, about half-way down the room, is another touching exhibit: a velvet coat that belonged to Oliver Goldsmith. It is one of the many things in this Museum which brings us very near to the human life of men long dead. Goldsmith, vain, awkward, uncouth in society, extravagant, not too strict in his habits, must have had some quality more striking and appealing than his genius (tender and delightful though that genius was), to make him an intimate of the circle of Johnson, and Reynolds, and the jealous Boswell. In their company he wore this very coat, and 
"strutted about, bragging of his dress, and I believe (says Boswell) was seriously vain of it. . . . 'Come, come,' said Garrick, 'talk no more of that.' ... Goldsmith was eagerly attempting to interrupt him, when Garrick went on, laughing ironically, 'Nay, you will always look like a gentleman ; but I am talking of being well or ill dressed.' 'Well, let me tell you,' said Goldsmith, 'when my tailor brought home my bloom-coloured coat, he said, "Sir, I have a favour to beg of you. When anybody asks you who made your clothes, be pleased to mention John Filby, at the Harrow, in Water Lane." ' Johnson. "Why, Sir, that was because he knew the strange colour would attract crowds to gaze at it, and thus they might hear of him, and see how well he could make a coat even of so absurd a colour'" (Boswell's Life, I769). The breeches of the coat, according to Dr. Birkbeck Hill, cost $\mathcal{L}_{\mathrm{L}} \mathrm{I}, 4$ s. 6 d. : a "half-dress suit," made at the same time, cost $f_{\mathrm{I}} \mathrm{2} 2$, I2s. ; and Filby's name has lived even longer than his simple commercial request might have led him to hope. He was a good friend to Goldsmith, who, perhaps, never paid him for this coat of which he was so proud: for Goldsmith died $£ 2000$ in debt. But as to that, let his epitaph be the words of that noble man who knew him so well and helped him so generously"Let not his failings be remembered; he was a very great man."

Yet one more personal relic. In the case of gloves in the middle of the room is one that belonged to " the most gorgeous Lady Blessington," a brilliant 
meteor of society in the first half of the nineteenth century. She was an Irishwoman, whose beauty and literary skill (and at first also her husband's wealth), made her one of the most prominent figures in London from about $I 8 I 5$ to $I 849$, when she died in Paris, a refugee from the debts her extravagance had caused. She was a friend of Byron, and her salon-in St. James's Square, first of all, and afterwards in Seamore Place-was frequented by the most eminent people of the day.

There are a few other objects in this room, apart from the succession of costumes and weapons, which may be dealt with here. On the left-hand wall, for example, is a coverlet of crimson velvet used at George IV's coronation. In the central case near this is the blue Garter of the Order of the Garter, aiready mentioned. There is on the left a fine caseful of beads and silk purses, of the kind that loving young ladies were wont to make for their admirers a hundred years ago; in a case in the middle of the room, close by, are sad little bead animals and a toy sceptre ornamented with glass beads, of an earlier date, that children must have played with no less lovingly. At the far end, on the left, beyond the exit door, are three costumes which hardly fit in with the series elsewhere in the room. One is the Blue Coat dress already mentioned-virtually the uniform of a London apprentice under the Tudors. Another is the official costume of a Lord Mayor of London. It is difficult to say how long this has been the Mayor's dress : for at least five centuries he has been decked out in special robes. Finally, there is 
clerical garb of the eighteenth century, when, though there were many good and holy men among the clergy-John Wesley among them-there were enough of a different character to make it almost uncommon to find a kindly reference to them in the literature of the day. The churches were formal and yet domestic in appearance, with their huge pews and three-decker pulpits; and the solemn black robes and white bands suited them. The portrait of an ideal clergyman of the eighteenth century is lovingly drawn by Goldsmith in the Vicar of Wakefield.

To come now to the main bulk of the costumes. As has been said, they are not arranged entirely in chronological order; but if a short account is given here of the chief changes from time to time, it will be easy to recognise the various types of dress, the differences in the details of which are mainly in the richness and diversity of the decorations. In fact, when we see a collection such as this, the impression at first given is of sameness of cut but difference of material. It is only when, say, a seventeenth century costume is contrasted with one of a whole century later that the sum of the small alterations and developments is realised. Take such a thing as a hat. The flat caps of the early Tudor period were succeeded by a kind of "tall hat"a high-crowned, well-brimmed hat, in shape not at all unlike the article of to-day. Under the Stuarts the crown was gradually reduced in size and the brim enlarged. When the brim became inconveniently wide (as it did in the Puritan fashion, 
though in this the crowns were also very large), one part or flap was folded over or cocked up-the typical cavalier fashion. Then another piece of the broad edges was cocked up, and finally, in Queen Anne's reign, the remainder of the edge, the third flap, was also cocked, and there was the cocked hat complete, looking as if it could never have had any connection with the steeple or high-crowned hat, but in truth its direct descendant. That is an instance of the way in which careful observance of all intervening stages builds up a full story of evolution-just as the story of the Stone Age was built up, as has been pointed out already.

The earliest dress in the Gallery, apart from the Tudor costumes already mentioned, is in the same case as the Tudor garb-a lady's dress of the seventeenth century. In the Seymour Lucas case on the left, is a buff coat of about the same period, and there are also some military dresses of the time. Military dress, up to the Commonwealth, practically meant any dress the wearer chose or could afford, with weapons and perhaps a breastplate added. The first attempt at uniformity on any large scale was in I645, when Fairfax dressed all his men in red -the colour which was to remain the distinguishing mark of the British Army till it was superseded by the neat, efficient khaki of to-day. Armour was given up in the reign of Queen Anne. But in the case on the right of the entrance door will be seen a small vestige of armour which lived on even later -the gorget, the then meaningless survival of the ancient neck-guard of the Middle Ages. (The 
modern Life Guards' breastplate is said by Mr. Clinch in his English Costume, not to be a survival, but to have been invented or revived in $\mathrm{I} 820$ for George IV's coronation.)

Under the Stuarts, women's dress lost, in one way, the stiff, boarded-up appearance it had had in the days of Elizabeth, when the farthingale made a sort of square platform at the hips, and the upper part of the body was encased in numerous stays. The stays remained, though they became a little less severe as the ruff gave way to the "fall " (a kind of band over a white collar), and that in turn to the magnificent lace collars so familiar in portraits of the beauties of Charles II's and William III's courts. The farthingale, on the other hand, was eventually succeeded by something hardly less artificial in the hoop, which varied in size from reign to reign and even from year to year in a most haphazard way. Large feathered hats, much the same as men's, were worn instead of the tall hat of the Elizabethan age.

Men's costume changed even more. The "vest" or close-fitting overcoat, which was worn in or soon after Elizabeth's reign-a garment perhaps not unlike those "sweaters" of to-day which are made to button in front-the vest grew rapidly into the coat with wide skirts, and trunk-hose and the quilted coverings of the thigh developed into knee-breeches. Wigs for men came into general use; and they could be very expensive. $£ 5$ was paid for one by a fine gentleman in 1663 - as much as he usually gave for a complete suit. 
Speaking generally, we might say that the seventeenth century wore habitually clothes (trousers excepted) which can be recognised as direct ancestors of the clothes of to-day, not separated by so great an apparent gap as thcre is between Tudor costume and ours. Yet the Tudor dress was, as has been said, but an earlier stage of the Stuart dress. It was, in fact, the introduction of foreign accessories-lace, fine buttons, and the like-which gave the latter period its seeming originality.

Before considering the typical eighteenth century costume, let us look at some special articles of dress which in this gallery have a case to themselves. They go back, in some instances, much earlier than the period with which we are now chiefly concerned.

First of all there is a case of boots and shoes, in the centre, near the door. Shoes and boots-the correct historical order, as far as England is concerned-begin in the Museum, as we have seen, in Roman times (see p. 26). The Celts, apparently, wore a kind of half boot, of hide or skin, all in one piece, with a lace round it-a sort of mocassin, perhaps. The Roman sandal, of course, was really meant for a better climate than England's, and it did not continue in general use after Rome withdrew from Britain, though the Saxons wore it to some extent. The Saxon shoe was very much like the Celtic, and there was no great change under the Normans, at first. It was in the reigns of Henry I and Stephen that the long pointed toes began to appear (see illustration, p. 57); the very long-toed shoes called Poleyns, or shoes à la poulaine, were 
first worn in Richard II's reign, one of the most extravagant periods of English costume; the toes were stuffed with wool or moss, and in the case of very extreme patterns, the tips were curled backwards and fastened by a chain to the wearer's knees. Side-lacings were worn in the middle of the fifteenth century.

About A.D. I500 the fashion changed. Pointed toes disappeared, and the foot-covering became very blunt and sturdy, of the "bear's paw" shape. But it was as yet not much more than a sole with a covering for the toes. As it spread a little further over the foot, it began to be slashed-cut to show the coloured hose underneath.

From Elizabeth's time onwards both upper and sole grew more elaborate. Buckles were worn, and in the seventeenth and eighteenth centuries were wonderfully rich and varied (the buckles in a case near the shoes, however, seem to be knee-buckles rather than shoe-buckles). High heels also came into fashion, at first in the form of chopines, or detachable clogs. Clogs were in use for many generations - they were an obvious necessity in the mud for which London was celebrated. Jack-boots seem to have grown out of the high-flapped military or travelling boot ; there is an enormous one of the Commonwealth period in a case on the left, and the mounted soldier in the middle of theroom is wearing a fine pair.

The chief changes in the eighteenth century were in the 'richness of the material for ladies' shoes, and the height of the heels, and in the size 
of the flap and buckle on men's shoes. About 1800 , to the annoyance of the buckle-makers, strings began to be used, and thenceforward-with minor improvements like patent leather and special polishing materials-boots and shoes were much as we know them to-day. The early nineteenth century saw many pretty and elaborate shapes in ladies' boots-for instance, the fine little pair of satin, which, if they had only fur round their tops, might have been the very boots with which Arabella Allen fascinated Mr. Winkle.

Gloves have a simpler history, because when a glove was once invented, there was not much room for improvement : almost the only change that could be made was in the ornamentation of the material. Gloves were worn in England at least as early as Saxon days. It was, however, in the Middle Ages that they began to be regarded as something precious: they were richly adornedoften with jewels, and had a distinct ceremonial use-for instance, as a token of defiance, or a symbol of office. As much as $£ 5$ was paid for a pair in the fourteenth century - a much greater sum then than now. London, by the way, owes a curious debt to gloves. It used to be customary for bishops, on their consecration, to present a pair to all who came to the ceremonial dinner that followed the event-a considerable expense. After the Great Fire, however, Charles II abolished this custom-on condition that all bishops to be thereafter consecrated should give not less than $£ 5^{\circ}$ to the fund for re- 
building St. Paul's-or else not be consecrated. In sixteen years, fourteen bishops in all contributed fIr5o in this way.

The Museum's collections of gloves contain some very fine specimens. Lady Blessington's has already been mentioned. Close to it is a wonderful little pair for a child, with delicate pictures stamped on the flap. At the left end of the case is an even greater treasure-a pair made of chicken skin. The chief historian of gloves is not quite convinced that gloves ever were made of this material (which was chosen for its softness), so the rarity of such a pair can be guessed. They are probably of the seventeenth century, in which "chicken gloves" are occasionally alluded to.

Fans are almost part of the history of manners rather than of costume. (They too, by the way, are said to have been occasionally made of chicken skin.) They have been used in various forms all over the world for centuries. In England they were most important and popular at the period when manners were most elaborate and affected-the eighteenth century. The mock suggestion of snuffbox drill for men has already been mentioned. A similar suggestion was made in regard to fans-the woman's weapon in the warfare of politeness, as the snuff-box was the man's. The Spectator gives a satirical account of a master of "the Exercise of the Fan, according to the most fashionable airs and motions that are now practised at Court. The ladies who carry fans under me are drawn up twice a day in my great hall, where they are instructed 
in the use of their arms, and exercised by the following words of command:

Handle your Fans,

Unfurl your Fans,

Discharge your Fans,

Ground your Fans,

Recover your Fans,

Flutter your Fans."

Umbrellas were not regarded as necessities, in spite of the English climate, till quite late in the eighteenth century. They have, of course, been in use in more southern climates since very ancient times, but they were very slow in coming into favour in England. They were known, in the form of sunshades, in the seventeenth century, but were little used. In the eighteenth century they were used by women to protect them from rain, but not by men, until Jonas Hanway, an eminent philanthropist, introduced the habit in the last half of the century : crowds used to follow him, amazed at the strange sight. The "macaronis," or fashionable young men of $1770-80$, however, seem to have used umbrellas earlier than this, and were thought ridiculous in consequence-more ridiculous, that is, than even their other extravagances made them. Canes, during this period, reached the highest form of fashion and elegance, as the beautiful china cane-tops in the Joicey collection showed. The "great " age of the sunshade and parasol was the Victorian era.

Hats have already been mentioned. But it may be added here that the headgear which was, above all other articles of dress, the mark of the self-respect- 
ing Englishman in the nineteenth century, the tall hat, created on its first appearance in London an even greater sensation than Jonas Hanway's umbrella. John Hetherington first wore one, in I797; and he was prosecuted for causing a breach of the peace thereby. An immense crowd gathered to see the gleaming chimney-pot, and it was solemnly alleged by the police that ladies fainted in terror at the sight. Why or how he invented the preposterous hat, is not known; it can have been developed from nothing worn during his lifetime. It may have been based upon the Elizabethan and Puritan high-crowned hat; but that, as has been said, had long ago turned into something quite different.

There is a case of ladies' hats here, too; but they are for the most part of a rather later period. They are the wonderful straw bonnets of the Regency and Early Victorian ages-headgear which caricature has perhaps too often made to seem ugly. It is true that the Victorian age produced bonnets of fearful and wonderful shapes which it would be hard to call beautiful; but the broad "coal-scuttle" had a charm of its own. The same period saw the use of shawls, of which the Museum has some good examples. It also revived hoops, by the name of crinoline, which the early volumes of Punch delighted to ridicule.

The weapons in this room represent the perfection of what might be called the duelling period. Pistols were not invented till the last half of the seventeenth century, but as soon as they became of 
convenient size, they were used for this form of "private war." The very long musket came from Spain early in the seventeenth century, and was soon followed by the device which made the sparkstriking apparatus part of the weapon; previously it had been necessary to carry a fuse and light it before the gun could be discharged. The new invention made pistols possible. All the apparatus of the wheel-lock pistol is shown here-the flints, the powder tester, the ramrods, the little armoury of gunsmith's tools for mending and cleaning the weapon.

The coaching pistols remind us of the insecurity of the roads : even the streets of London itself were hardly safe. The eighteenth century was the heyday of the highwayman, footpad, and pickpocket.

To return to costume more generally. Throughout the reigns of Anne and the Georges it fluctuated : now there was exaggeration in one respect, now in another. It was perhaps in hair-dressing that the exaggeration was most startling. "There is not so variable a thing in nature as a lady's headdress," says Addison. In a case on the far lefthand corner of the room, and in the dining-room group at the end, are some of the most amazing erections ever set on the human head in the name of fashion. The ordinary wig was large enough, and demanded plenty of attention: the "pipes" by which it was curled have been mentioned ( $p$. rog)-there are specimens here. But the macaronis, male and female, of $1770-80$, exceeded all bounds. Huge erections of hair, based upon a 
foundation of tow, were built up for two or three feet in height, and were covered with ornaments of the wildest kind. These terrible " heads " ("I will bring new heads for my sisters," writes a young gentleman of London to his mother in the country), with all the grease and dust they must have harboured, were expected, when once properly set up, to last in good condition a fortnight or three weeks.

The hoops of a little earlier were hardly less exaggerated. They were "blown up into a most enormous concave," and excited the ridicule of $\mathrm{Mr}$. Spectator : but he had the fairness to make a woman answer that "the skirts of men's fashionable coats formed as large a circumference as our petticoats ; as these are set out with whalebone, so are those with wire."

Those are the extremes of eighteenth century fashion: and extremes of fashion, not unknown in even the twentieth century, are often rather absurd. But when we look at the average dress of that period, as it appears in many cases in this room, it must be admitted that it was both stately and graceful. The social life of the time, among all but the lowest classes, was full of display-not necessarily vulgar display, by any means: people liked fine and beautiful garments, and the habits of public intercourse gave them the chance to show them. It has been said that this was the age of the coffee-house : that implies that it was an age of social assemblies and public parades. A satirist proposed to start a newspaper which he was sure would be immensely successful : it was to deal solely with "plays and 
pantomines, masquerades, ridottos, concerts, the smart comedians, Vauxhall, Ranelagh . . . auctions of china, knick-knacks, and cockle-shells . . parrots, puppies, and monkeys, lost, stolen, or strayed." Everyone went to the fêtes and promenades : everyone had a favourite coffee-house : everyone wanted to be in the fashion-except those unhappy persons whose fate we shall see in the prison section of the Basement. London under the Georges, in fact, had a disease of gaiety - a grave intentness on leading a life of cultured pleasure. Goldsmith pretended to think it gloomy and monotonous, so serious was its aspect. But there was variety even in its uniformity of fashion. Addison writes as if London were almost several cities: "The inhabitants of St. James's, notwithstanding they live under the same laws and speak the same language, are distinct people from those of Cheapside, who are likewise removed from those of the Temple on the one side, and those of Smithfield on the other, by several climates and degrees in their way of thinking and conversing together." He himself tells us how various the "clubs" were-the coffee-houses being but clubs open to all who could pay for their refreshment :

"There is no place of general resort wherein I do not often make my appearance; sometimes I am seen thrusting my head into a crowd of politicians at Will's, and listening with great attention to the narratives that are made in those little circular audiences. Sometimes I smoke a pipe at Child's, and whilst I seem attentive to nothing but 
the Postman [newspaper], overhear the conversation of every table in the room. I appear on Sunday nights at St. James's Coffee-house, and sometimes join the little committee of politics in the inner room, as one who comes there to hear and improve. My face is likewise very well known at the Grecian, the Cocoa-Tree, and in the theatres both of Drury Lane and the Haymarket."

"Coffee, that makes the politician wise,

And see through all things with his half-shut eyes,"

was not the only drink at these resorts: chocolate and tea and stronger fare could be and were obtained.

The fashionable man's day was simple. He would rise about nine, attend levées, or read, till eleven. At noon he would go to the coffee-houses, borne thither in his own or a hired chair. He might have a turn in the Park till two; then would come dinner at a tavern-lasting, perhaps till six o'clock; then to the play, or to some entertainment, or to a reception, and last of all to the coffee-houses again for cards and conversation. The fine ladies' day would be much the same, except that they would spend as much time over shopping as the men spent over dinner. They would sally forth in their coaches or chairs, "their hair plastered up with pomatum, their faces patched to taste, their trains bundled up in a heap behind, and rustling at every motion," and would spend hours over the mercers' counters, or talking scandal over a dish of tea, or running hither and thither to see the latest piece of "Chinese" ware. The poorer folk had their clubs too. The Spec- 
tator gives a humorous account of one, from which we may quote one or two rules: it was called the Twopenny Club, that sum being the price of membership :

"II. Every member shall fill his pipe out of his own box. ...

"IV. If any member swears or curses, his neighbour may give him a kick upon the shins. . . .

"VII. If any member brings his wife into the Club, he shall pay for whatever she drinks or smokes. . . .

"X. None shall be admitted into the Club that is of the same trade with any member of it."

The parks and pleasure-gardens will be dealt with when we reach the views of them in the Basement. Only one other institution need be mentioned here -one of the coffee-houses which has provided the London Museum with a valuable exhibit (see p. 5I). Don Saltero's was one of the well-known coffeehouses, but it was a museum as well, In it were, as Steele said, "ten thousand gimcracks round the room and on the ceiling." It was opened in I695 by one Salter, a barber who drew teeth and wrote rhymes, and it was visited by many well-known people. Sir Hans Sloane, founder of the British Museum, who lived not far off, gave many objects to the museum, but it seems to have contained a good deal of rubbish as well. The house was in Cheyne Walk, Chelsea.

Don Saltero's, in fact, was by way of being the London Museum of the day. (It is to the eighteenth century, it should be remembered, that we owe the greatest of all museums-the British Museum, 
opened in I759); and now it is only a name in another and better London Museum. So, too, the coffee-houses and the fine dresses, and the "heads," and the snuff-boxes and canes are all laid by and ticketed and labelled; by the sum of them we reckon up and praise or condemn the age in which they were things of joy and beauty. But we live by the thoughts and the deeds, good or evil, of the men and women to whom they were real. 


\section{CHAPTER XII}

THE THEATRICAL AND VICTORIAN ROOMS

THE Costume Room opens into a little lobby or antechamber which contains the chief theatrical relics of the Museum. It is an irony of fame and fate that the very gifts which in a living actor bring him, or the people he impersonates, into the closest acquaintance with his audience, are the qualities which death renders least credible. Nothing is less easily made real than an account of how a player acted on a certain occasion; even if the very tones of his voice could be recalled-as they can to-day by the gramophone-there is still some individual quality which disappears with the man himself. And when the character of acting has changed so greatly as it has in England during the last thirty or forty years, the old players, with their gestures as it were frozen stiff in pictures and statues, seem like something less than ghostsactors indeed, but of a fantastic stage in a strange land. Almost, one might say, the tinsel pictures here hung on the walls are symbols of the frailty of theatrical fame.

But it is possible to learn a little of some of them. Garrick, in particular, was the friend of great men, 
and like the incomparable Mrs. Siddons, frequented the society of wits and teachers and writers in a period when none too great respect was paid to actors. Johnson, as usual, summed up with profound good sense his chief service to the stage: "Here is a man who has advanced the dignity of his profession; Garrick has made a player a higher character ; " and he paid him also that superb compliment : "His death eclipsed the gaiety of nations, and impoverished the public stock of harmless pleasure." Practically all who saw him-Walpole is an exception of some importance-agree in praising him lavishly. "In Lear Garrick's very stick acted." "That young man never had his equal as an actor, and he will never have a rival," was Pope's verdict, and Pope was not generous of praise. "An abridgment of all that was pleasant in man," said Goldsmith, of whom Garrick wrote the bitterly true mock epitaph :

"Here lies Nolly Goldsmith, for shortness called Noll, Who wrote like an angel and talked like poor Poll."

It is said that he was vain and mean. He may have been : but he was the close friend of men who were neither, and when they have admitted his faults, there is a great amount of solid and attractive character left. The truth perhaps is that he had what would have been called, ten years or so ago, the artistic temperament : which did not fit in well with eighteenth century standards. We are able to know him as no other actor save Macready is known : and it is evident that he was personally 
interesting and remarkable, while, if it is ever possible to set up standards'of comparison in such matters, he was the greatest of English actors. Perhaps the best short description of his appearance is that by Miss Hawkins : "I see him now in a dark blue coat, the button-holes bound with gold, a small cocked hat laced with gold, his waistcoat very open, and his countenance never at rest, and, indeed, seldom his person."

But to describe in full all the actors of whom some relic or other is to be found here would be impossible. Many of the names are familiar traditions: Jenny Lind, the "Swedish Nightingale," whose character was as sweet as her voice; Phelps, great in Shakespeare, and equally successful in a comic part like Bottom and a tragic one like Macbeth-Malvolio, perhaps, being his finest piece of acting; Kean, the most wonderful Richard III of the stage, whose fame was such that when he acted the profits of Drury Lane Theatrewere doubled, and in sixty-eight nights "the theatre cleared upwards of $£ 20,000$ ": Kemble, one of the last of the old declaiming, pompous actors : in his reign at Covent Garden occurred the celebrated O.P. riots. The theatre had been burnt down in I808. In the following year it was rebuilt, and was reopened in September I8, with Kemble as Macbeth. But he had increased the price of seats-the pit from $3 s .6 d$. to $4 \mathrm{~s}$. and the boxes from $6 \mathrm{~s}$. to $7 \mathrm{~s}$. The moment he appeared on the stage the audience drowned all speech with hoots and groans and yells; nor could Mrs. Siddons, even then still the greatest of actresses, 
but destined to retire from the stage three years later, obtain a better hearing. The play was abandoned. The next night, and for three more nights, the disturbances continued. On the fifth night Kemble tried to make an explanation, but it was not accepted. The audience believed that Kemble had increased the prices mainly in order to pay Madame Catalini, the foreign actress, the then enormous salary of $£$ I5O for a "week " consisting of two nights; Kemble said he merely wished to defray the cost of rebuilding the theatre. He attempted to soothe the audience first of all by. cancelling Madame Catalini's contract, and then by importing pugilists into the pit-which resulted in unseemly and serious fighting. Finally, Kemble had to yield; he restored the O.P. (old prices) and made a humble apology to the audience.

The tinsel pictures are examples of a peculiar "art" which even yet lingers on in London : they are prints, coloured by hand, with tinsel stuck on above the colour. They are homely, simple reminders of the idols of the stage-of actors and actresses remembered for some special gesture, or scene, or speech, which now, because it is separated from both play and player, seems a mere "theatrical" posture. Hardly less formal and unnatural are the Staffordshire figures in the case on the right hand; and of all the fine realities and brave pomp of the old stage, all that is left are a few "properties" that once were instinct with mimic tragedy.

The history of the early theatres has already been told (see p. 76). The robes worn by Sir Herbert 
Tree as Cardinal Wolsey in Henry VIII bring us down to the present day. But there is a long story implied in the picture of Old Sadler's Wells, on the wall. It can only be told brieffy. It is, in little, a summary of the change in London's habits of amusement ${ }^{1}$ between the Restoration and King Edward VII's reign. A certain Sadler, in the reign of Charles II, built a " music house" (a one-storied building of wood) in Clerkenwell. In 1683 he discovered an old well, fed by a chalybeate spring ; and as such springs were then the fashionable "cure" for most of society's ailments, he laid out gardens to make the place an attractive resort. The gardens were in use for a century or more, though the waterdrinking fell out of fashion. Sadler's Wells, in fact, became a sort of Earl's Court of the eighteenth century : people took the air and refreshments in the gardens, and saw performances of various kinds in the music house. In the Basement is a print of an "animal comedian" of Sadler's Wells-Spinacuti's wire-walking monkey, which appeared there in 1768 . Three years before that a new theatre had been set up in the place of the Music Room, by the then proprietor, Rosoman; parts of it stood till the twentieth century. At this theatre many famous performers appeared: the most notable were Grimaldi, the great clown, whose life ended so pathetically in want and disease; and Edmund Kean. Sadler's Wells became finally a theatre pure and

1 For many details here, and in the later accounts of similar places, the author is greatly indebted to the standard work by Mr. Warwick Wroth, The London Pleasure Gardens of the Eighteenth Centiry. 
simple, and reached its highest point of reputation and excellence under Phelps, who for eighteen years (I844-62) produced there Shakespeare's and other plays. Later it became a music-hall, in the modern sense of the term (which is not so far removed from the scope of this "music room" in the eighteenth century). Its position, now that Clerkenwell has become a rather mean district of houses and warehouses, makes it an unsuitable site for either a great theatre or pleasure gardens. So London changes from century to century : fields and watering-places in one generation are bricks and mortar the next, and a grandfather may see squalor and overcrowding where in his boyhood was gaiety and ease.

Cremorne Gardens, for which there is an admission ticket in the glass case, were also famous-in the nineteenth century; but their fame became notoriety after a very short time. They were in Chelsea, at the other end of Chelsea Reach from Ranelagh; and the entertainments there tended to become noisy and disreputable. Many balloon ascents took place from the Gardens, which were closed in 1877 .

This theatrical lobby leads into the Victorian Room, which is filled mainly with royal dresses of the nineteenth and twentieth centuries, about which it is difficult to say much. There are, however, other exhibits besides the costumes. On the right, for instance, is the chair in which Queen Charlotte, George III's wife, died in I8I8 at the polky little palace at Kew ; and here too is the cradle of Princess Amelia, George III's youngest daughter. 
Between the door and the window, on the right, is a collection of the famous dolls made by Queen Victoria and Baroness Lehzen. They came to the London Museum from Kensington Palace, where the Princess, as she then was, dressed them in her childhood. "Her Majesty was very much devoted to dolls, and indeed played with them till she was nearly fourteen years old. Her favourites were small dolls-small wooden dolls, which she could occupy herself with dressing, and who had a house in which they could be placed. . . . The Queen usually dressed the dolls from some costumes she saw either in the theatre or private life." 1 The delicacy of the stitching is very remarkable. But the Queen's hands (noted for their smallness and fineness) were clever in many ways. There is in one of the central cases a little book of sketches by her, which are wonderfully well drawn. The ridingwhips in the same (central) case remind us that these same hands were skilled with the reins also. The Queen was an excellent horsewoman, and often rode with the Prince Consort, as many popular pictures of the day testify, among them one of the tinsel pictures in the Lobby.

Other relics of Queen Victoria are the bonnet which she wore at the opening of the Great Exhibition of $185 \mathrm{I}$; the Exhibition has already been mentioned (see p. I75) : here, too, are her first cap; her throne cushion; the medicine chest of her father, the Duke of Kent (in a case at the far left end of

${ }^{1}$ Sir Henry Ponsonby, quoted by Mrs. F. Nevill Jackson in Toys of Other Days. 
the room); the uniforms of her consort, Prince Albert, and a set of beautiful chessmen, of painted wood, that belonged to him. Opinions, perhaps, will differ for many years to come as to the precise character of the great Queen-as to her ability, her foresight, her personality : but whatever be the final verdict of history, it is certain that in her long reign she impressed herself deeply upon the nation, and set an example of dignity, goodness, and sympathy, which went far to counteract the unpopularity of George IV and William IV. She was, perhaps, more than any monarch since Elizabeth, the unconscious embodiment of the nation, so that at her death it seemed as if something permanent in English life had been suddenly and unexpectedly removed.

On the right hand of the room are memorials of her eldest son. Here are wedding favours of the Danish colours, worn to welcome the beautiful Princess Alexandra, who was received in England in I 863 with a warmth and affection that were not lessened when many years later she was QueenConsort of King Edward VII. In the case in a right-hand window is a watch-chain of Queen Alexandra's hair, given by her to her husband. Here, too, are boxes of the cake of many royal weddings; the gloves and muffler of King Edward; the Royal Victoria and Albert Orders, already mentioned (see p. 73).

One isolated object in this room, out of place chronologically, but placed here because it is lent by H.M. the King, suggests another chapter of 
naval history. It is a stick made of the timbers of the Royal George, which, in I780, sank in harbour, in calm weather, with Admiral Kempenfelt and all the crew. Tlie navy, in spite of the war with France in progress, had been shamefully neglected once more; and no less than seventeen chief ships of the line were "unseaworthy, rotten, and unsafe." The Royal George was one of the seventeen: she sank because "some material part of her frame gave way, which can only be accounted for by the general state of the decay of her timbers."

The last case on the right hand contains passes and cards of admission to various state functions, and models of royal insignia. At the end of the room are the gorgeous robes of royal ceremoniesthe Coronation of King George $V$ and the investiture of the Duke of Clarence (King George's elder brother, who died in I892) as a Knight of the Garter. That order has already been mentioned (see p. 73); it may be added here that in addition to the Garter the "uniform" consists of a golden chain of interwoven garters, with a pendant, called the George, showing St. George defeating the dragon; a mantle of blue velvet; a hood of crimson velvet; a supertunica, or surcoat, of crimson velvet, lined with white; a plumed hat of black velvet; a broad blue ribbon worn across the breast from left to right; and a silver star with a garter and cross in the centre.

A coronation, it need hardly be said, is something more than an affair of brilliant robes, though the spectacle in Westminster Abbey on such an occasion is dazzlingly many-coloured. It is, perhaps, 
the most ancient continuous ceremony in the world; it has been held in the same place for eight centuries. Every act in the long service is full of venerable meaning, every piece of the regalia a symbol of some attribute of awe and majesty. The orb is the sign of supreme sovereign power; the temporal sceptre, of rule; the sword, of justice; the ampulla, or oil vessel, of consecration to the high office of king. Even the vestments used are said to have a partly religious significance, and when at last the king stands forth fully arrayed in the robes of coronation, he has taken upon him, symbolically, in those robes, a burden of precedents and duties, powers and rights, vows and obediences, which has grown up steadily and solemnly throughout the long generations of intercourse between the people of England and their hereditary kings. The golden mantle joins King George and the citizens of London to William the Conqueror; and William the Conqueror, in his charter and his coronation, did but recognise the immemorial foundation of his capital city, and its claim to lead the nation. 


\section{CHAPTER XIII}

\section{THE BASEMENT}

WE go back to the eighteenth century in the Basement, for the most part. Here is the wealth of prints and pictures of old London, and the relics of its humbler life, as well as of its more decorous buildings, and its parks and pleasure gardens.

The Basement is reached by taking the passage on the left of the central hall, and turning to the left. At the bottom of the stairs, in a corner which is usually rather dark, is a fine lead tank or cistern, dated I787. Just to the left of the door, on the wall, is a shopman's bill of I75I : the first item is "Superfine Hyson tea, £I os. od. a lb." Nearly opposite are three aged bicycles, one dated I850, all of an obsolete pattern. Those three exhibits are prophetic, so to speak, of most of the contents of the Basement. We are to see fragments of buildings of an age which knew, perhaps, better than any other the decencies of proportion for quiet dwelling-places-the lead cistern, apart from the charming design upon it, is beautifully proportioned : it seems to be just the right size, somehow -and that is the secret of proportion. We are to see the tea gardens and pleasure grounds of the 213 
epoch which first learnt to enjoy tea fully; and we are to see something of the life of the road in the eighteenth and nineteenth centuries.

Bicycles, as everyone knows, are comparatively modern inventions. Velocipedes - a frame of wheels very like a bicycle, but without treadles or chain, driven by the feet upon the ground-appeared during the Regency. The 1850 bicycle here shown is probably one of the earliest specimens. The old high bicycle, or "spider," was the most popular type till the 'eighties, when the "safety" superseded it; and the 'nineties were the great era of pneumatic-tyred safety bicycles, now themselves slowly yielding to motor-cycles.

The passage turns to the left, and at once the Georgian toy-shop window appears. It is a wonderful bow-front of the period of George III : its solemn curve and the small panes give it an air of dignified homeliness. In it are various enchanting wares: toy clocks, toy furniture for a doli's house such as that shown upstairs, bobbins for lace and bead work, a mouse-trap of the sixteenth century worked by weights: samplers (of which we have already spoken-see p. 90), a toy coach, perfect in every detail, and a set of prints for children of the Cries of London. Prints of this kind, often published in books, were common from I790 to I830; and all through the eighteenth century the cries were one of the most remarkable things in London. Almost every street-seller had a distinctive cry, sometimes a long verse. The only one heard at all fully nowadays is the old "Lavender" cry of the 


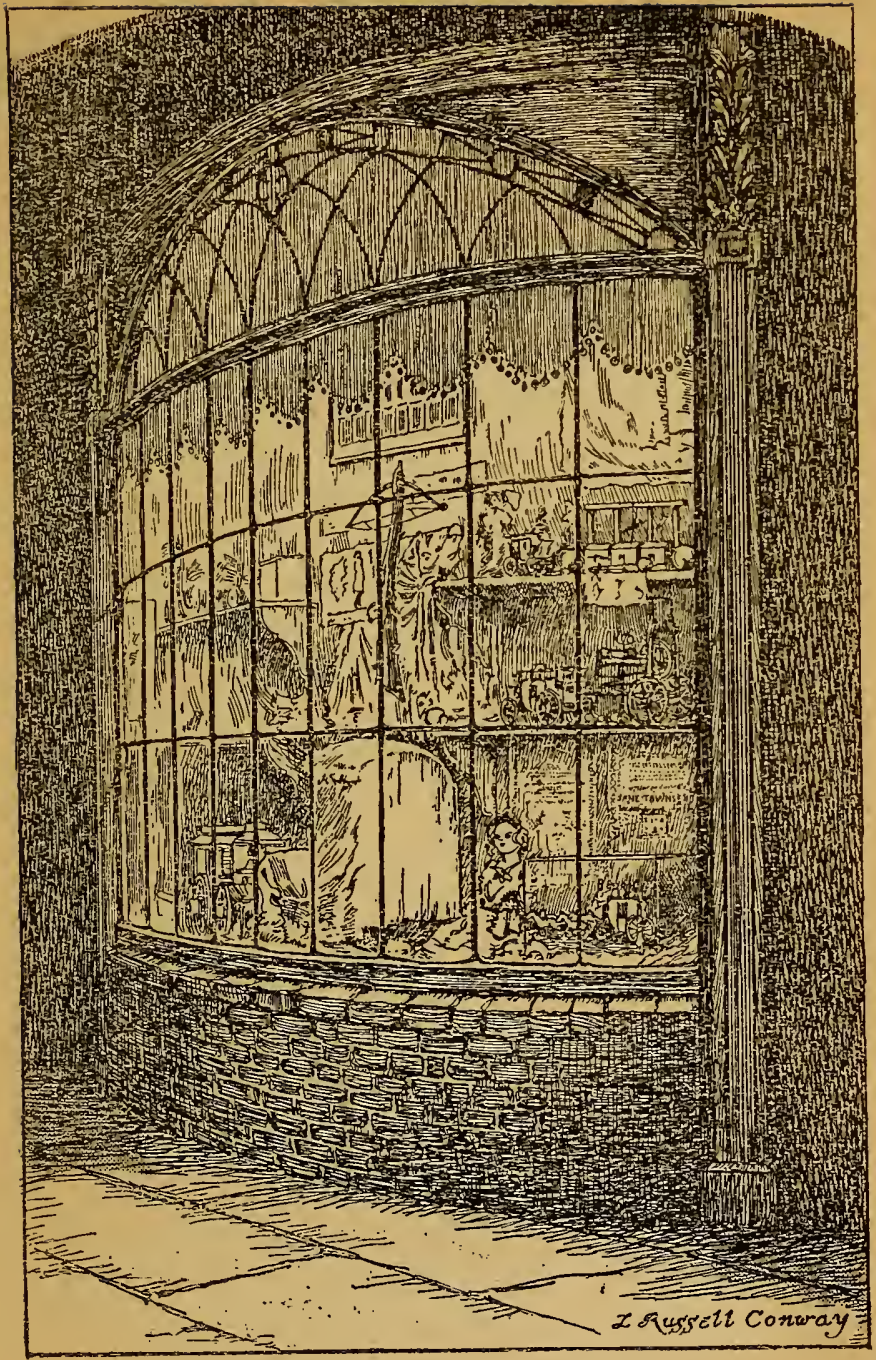

ThE GEORgIAN TOY-SHOP 

Mitcham sellers; a busy butcher's shop in a crowded shopping street on a Saturday night, with its continual "Buy, buy, buy!" is the nearest approach to the din of Georgian London.

Farther on, on the right, are some of the shop signs of the seventeenth and eighteenth centuries. It was a favourite remark of the essayists that London was crowded with all sorts of meaningless signs--that a blue dragon might mean, say, a bookseller's in one street or a wine merchant's in the next. What the old hanging signs were like may be seen still in Lombard Street, where the occupiers of houses restored or remade the old signs in honour of the Coronation of King Edward, and have retained most of them since. The signs here shown, however, have more meaning. A grocer is represented by what appears to be an Indian of some kind (perhaps Pocahontas), probably typical of Indian spices. Snuff and tobacco sellers used the figure of a Scot, who was popularly supposed to be especially addicted to snuff.

At the end of this passage is the Duke of Wellington's carriage, already mentioned (p. I83): and the route then leads past the fine models of Old London, including a picture of Baynard Castle as it was before $155^{\circ}$. These also have been already described (see pages 43,60, I03, II3). They are succeeded by a corridor containing a number of prints of Old London, chiefly of places with which the earlier chapters of this book have dealt. The most interesting is, perhaps, that of the opening of new London Bridge (the present bridge) in $183 \mathrm{I}$. Here, 
too, are some of the fine architectural remains of the Museum-two graceful plaster plaques, a stairbaluster of I725, an eighteenth century mantelpiece, and the beautiful doorway from New Inn, of the seventeenth century. New Inn, originally one of the Inns of Court, like Sergeant's Inn (p. 62) and the Temple (p. 64), was on the east side of the present Kingsway, north-east of Aldwych, and the last of its buildings was demolished when that great clearance was made. All these specimens of domestic architecture reveal the same characteristics as the leaden cistern-good proportions and good workmanship. In the houses and streets of the period ornament was not superfluous : beauty was not an addition put, if funds permitted, on to a useful thing-the useful thing was designed to be beautiful, and to fit its surroundings beautifully. There was no attempt at pride or pomp in these private houses : they were just the quiet dwellings of orderly, serious people (serious, as has been said, in their pleasures). They seem, perhaps, uniform in design and treatment: so they are, except in details; but so was the life of the day, except in details. They suited that life, and they adorned it soberly-they did not shout aloud that they wished to attract attention to their originality or their costliness or their size.

Hereafter follows the Roman Boat Room (on the right hand-the Basement is a labyrinth to which the clue is "keep to the right"). The Roman and the prehistoric boats, and most of the other objects in this room have been described (pp. I3, 20, 23). 


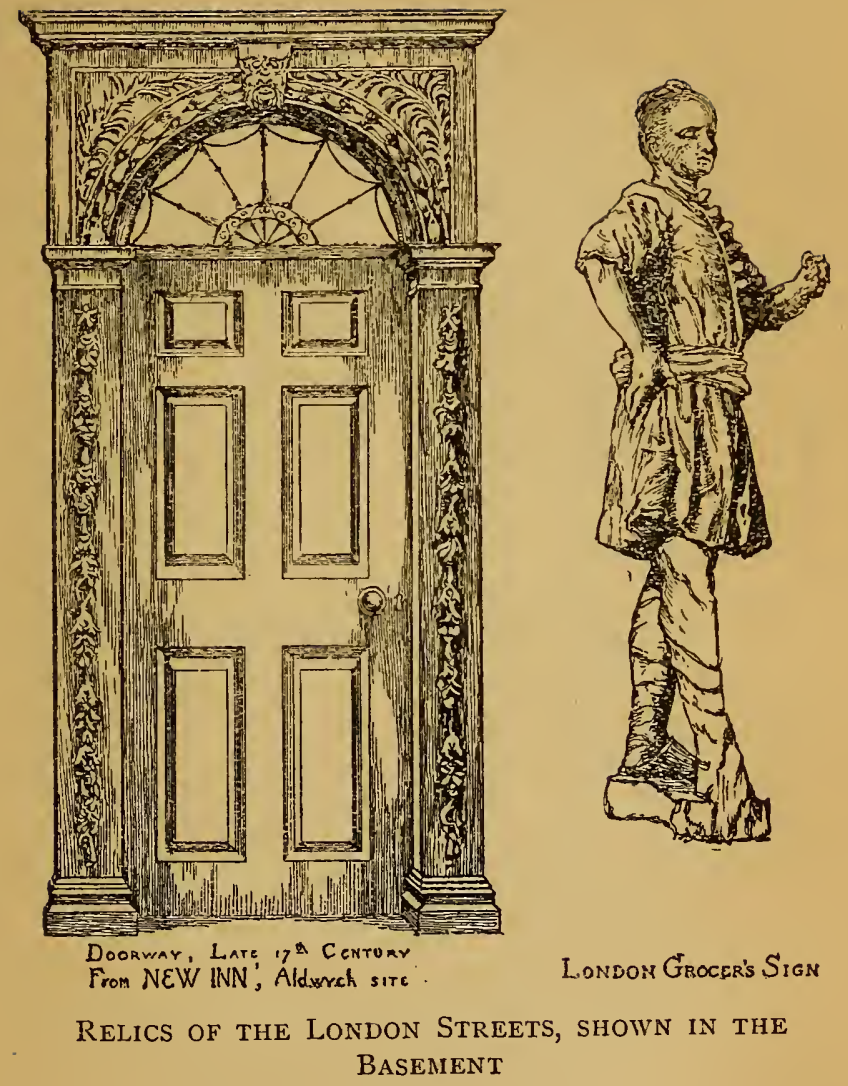



In addition to these exhibits there is also a model of Buckingham Palace front as it was till I9I3. That palace is now, and has been since about I862, one of the chief royal residences-the chief one in London since Queen Victoria's accession. It stands, as everyone knows, at the west end of St. James's Park. It is on the site of the old Mulberry Garden, planted by James I, who was desirous of encouraging the silk industry (which flourished, in one way, during his reign, as has been seen in the fine needlework of the period). Evelyn said of it in 1654 that the Garden was "the only place of refreshment about the town for persons of the best quality to be exceedingly cheated at." It contained a house, which was in the possession of Lord Arlington under Charles II and James II. In I703-5 the then Duke of Buckingham bought it or rebuilt the house, renaming it Buckingham House. It was bought by George III in I762 for $£ 28,000$ : there is a picture of it on the right-hand wall of the Jerningham Collection (see p. 223). Thenceforth it was Buckingham Palace. In 1825 George IV partly rebuilt and partly added to it. Other changes were made in 1837 and $185^{\circ}$, when the east front was added. This model of the Palace as it was through the greater part of Queen Victoria's reign, and the whole of King Edward VII's, hardly gives an idea of its inadequate appearance. It was of poor proportions, and almost always very dingy. In I9I3 the whole of the front was rebuilt, to be more in accord with the Victoria Memorial facing it.

The Roman Boat Room leads into a smaller room 
or lobby. On the right hand is a very perfect model of a mail coach of 1836 . The coaching days of England were as proud of themselves as the motor age of the twentieth century: spanking horses jingling along a fine road-the late eighteenth and early nineteenth centuries built greater roads than Rome's-the horn (a specimen is shown here) ringing merrily, the special pistols for the guard to deter highwaymen (which, apparently, he seldom did), the comfortable inns with their rosy landlords, roaring fires, neat chambermaids and wines, all the bustle and glory and human nature that seems inevitably to belong in England to anything to do with horses-those were "the good old days." It is true that the coaches were stuffy inside, and cold outside, the dangers from highwaymen very real, the roads not always good-least of all in winter, when snow or mud might stop the coach altogether, miles from anywhere-the passengers perhaps cantankerous, the inn charges outrageous, and their accommodation bad. But it has been settled by popular history that coaches were romantic; and romantic they were, if people like ourselvesfussy, cheerful, hasty, frightened-are romantic in other clothes and other situations; if the life of the past is such a fairy tale as we could make the life of to-day, did we but wish it eagerly enough.

The best picture of the coaching days can, perhaps, be obtained from Dickens' works, especially from that London encyclopædia, The Pickwick Papers.

The other half of the romance of the road is re- 
flected on the walls of this room. Here are pictures of Shillibeer's omnibus and the steam carriages already mentioned (see p. 178). Here, too, are views of some "Zoos" of early nineteenth century London-Bullock's (in Piccadilly, at the old Egyptian Hall, nearly opposite the end of Bond Street, and afterwards famous for Messrs. Maskelyne and Cook's entertainment: it was pulled down a few years ago); Exeter Change (a disused exchange hall on the north side of the Strand, afterwards rebuilt as Exeter Hall, the site of many missionary and religious meetings, now again rebuilt as a large hotel-the Strand Palacc); and the Surrey, in Surrey Gardens, Walworth (I83I-77), famous also for its panoramas.

Opening out of this lobby is the long room containing the very complete Jerningham Collection of prints illustrating the history of the London Parks. Besides the prints it contains some cases of objects of domestic interest : the Pall Mall set already mentioned (p. I29): "fellowship " badges-the insignia of trade unions, like the modern button-hole discs : some trade cards, more elaborate and picturesque than those in use now : park gate tickets, enabling the holder to enter the royal parks before they were made fully public : spectacles, snuffers, teeth, dentists' tokens, weights, hour-glasses. The tally-sticks in the second case on the left show an old and primitive method of reckoning : a stick was notched, and split, and each party to an agreement took a half of it. Cricket scores, by the way, were kept on sticks notched similarly, in the days when the 
present Lord's cricket ground was first opened, in $\mathrm{I} \mathrm{I} 4$ : there is a view of this Marylebone ground (the third and last headquarters of the M.C.C.) on the walls here.

Another little object which might escape notice, but is really typical of a whole generation, is in the third case on the left-a folded game, called "The Mansion of Happiness." It unfolds into a large sheet of type and little coloured pictures, forming the "board" for a game played in much the same way as the "race game." According to the number indicated by dice or a marked teetotum, the player goes forward so many stages, and is rewarded or penalised in various ways. It was a "moral and entertaining game," meant to teach goodness by way of play : the verses in the middle of the pictures run :

"At this Amusement each will find A Moral fit t' improve the Mind; It gives to those their proper Due, Who various Paths of Vice pursue :

And shews (while Vice Destruction brings)

That good from every Virtue springs.

Be Virtuous then, and forward press

To gain the Seat of Happiness."

It was first published in I80o, and the author's name was George Fox. He produced other games of the kind, one being called, without any disguise, "The Reward of Virtue." These gloomy diversions were issued in some plenty between $\mathrm{I} 780$ and I830, when children's amusements were all apt to be rather heavily burdened with instructiveness. 
In the same case are proofs that a certain amount of instructiveness was certainly needed. A game like "The Mansion of Happiness," of I792, in the possession of the present writer, suggests artfully that a teetotum might be used if dice were thought immoral. Why dice should be considered immoral in themselves the gambling relics in this case help to prove. They are the dice and betting discseach standing for a certain sum-in use at two famous London clubs where play was apt to run high-White's and Crockford's. Gambling was certainly a vice of the Georgian era : immense sums were lost at play by both men and women. At Almack's, a favourite resort in the 'seventies of the eighteenth century, "the young men of the age," says Walpole, "lose five, ten, fifteen thousand pounds in an evening." Fox, Sheridan, Selwyn, the Regent himself, all played heavily. Canning's father-inlaw, General Scott, is said to have won $£ 200,000$ at White's, and Lord Robert Spencer is credited with winning $£$ roo,000 at a sitting - after which he had the sense never to play again. Equally harmful were the public lotteries, abolished by law in $\mathrm{I} 826$. The State had even conducted lotteries, and sometimes put the profits to good use. In this case is a proposal for a lottery for a diamond valued at $£ 30,000$.

There are also in this room some fine early pianos, and on the right-hand wall a case of keys and passes for the royal parks, the roads through which were then not open to general traffic. One pass is for the King's Road, Chelsea. It ran from London to 
Fulham, and so was the easiest royal road to Kew. It was a private road of the King, and only those possessed of a key or of a pass could use it. It was doubtless the safest way across the Five Fieldsthe open space which is now Pimlico and Belgravia, and "where the robbers lie in wait."

Turn now to the prints of parks and pleasure gardens. Some of the first show the animal performers at Sadler's Wells, which have already been mentioned (p. 207). Others show various early balloon ascents. The Montgolfiers invented the balloon in 1783 . The first ascent made in England was accomplished by Vincent Lunardi, "Secretary to the Neapolitan Ambassador, and the first aerial Traveller in the English Atmosphere," on September I5, I784: he ascended at the Artillery Ground, Finsbury, and came to earth near Ware. Another early flight of his was from the Adam and Eve Grounds near Tottenham Court Road. His portrait is here, and pictures of his ascents, as well as of others : the subjects of George III were deeply interested in this conquest, as it seemed, of the air, which is not wholly subdued even by the subjects of George V.

On the left-hand wall, also, is a portrait of Dr. John Hill, an apothecary, botanist, writer of books and pamphlets, who came into conflict with many well-known men of the Georgian era. He also wrote a farce, which called forth a famous epigram-" "his farces are physic, his physic a farce is." He was a very able, but wholly unstable, man, whose talents deserved a better fate and wider recognition. 
A little further on is a portrait of "Bagnigge Wells Beauties," with the enormous headdresses already described (p. I97). These "Wells" were another set of Clerkenwell springs, like Sadler's Wells, near a house said to have belonged to Nell Gwynne. It was a favourite and fairly fashionable resort from I759 to the end of the century, though it is also spoken of slightingly as the pleasure ground of "cits" - the City merchants and their wives and apprentices. The "Dog and Duck," shown in a print close by, was in the St. George's district, near Newington Butts. It was a very ancient tavern, which began to trade in its natural mineral waters early in the eighteenth century. It was very respectable at first, and the waters were seriously recommended by doctors. But late in the century the gardens grew disreputable, and when Bethlehem Hospital was moved from Moorfields in I8I2-I4, the tavern was pulled down, and the great asylum erected on its site.

The Pantheon (still standing in Oxford Street, and used as a wine merchant's office) was built in the eighteenth century as a concert hall, and many masquerades like that shown in the print in this room were held there. "The Battle of the Umbrellas," on the end wall to the right, explains itself : umbrellas were in I784, as has been said (p. I95), a strange novelty. Near by is another leaflet "Printed on the ice, 1684" (see p. I28).

But the pleasure gardens of the greatest celebrity were Vauxhall and Ranelagh-rivals for many years. Ranelagh (part of the Gardens of which, 
replanted, remain, to the east of Chelsea Hospital grounds) was opened in I742, the famous Rotunda (a huge domed building, rather like the Albert Hall or the British Museum Reading Room) having been built in the grounds during the previous year. "Everybody that loves eating, drinking, staring or crowding is admitted for twelvepence" (half a crown was charged later). It was, as a rule, conducted in the most orderly manner, and Dr. Johnson himself was affected by its charm : "When I first entered Ranelagh, it gave an expansion and gay sensation to my mind, such as I never experienced anywhere else." The amusements, apart from the delight of mere promenading, were chiefly concerts (at one of which Mozart appeared, at the age of eight) and masquerades, which George IV, as Prince of Wales, frequently attended.

The place was closed as a pleasure garden in I805, and the Rotunda pulled down. The present Ranelagh Club at Barn Elms has no connection with it except in name.

Ranelagh was reached by road across the fields from London; and often so great was the crowd of visitors that Walpole speaks of being "held up " on the road in his coach for over half an hour. The journey to Vauxhall was made more romantically, by water, and travellers from Whitehall (the boat fare was sixpence) or the Temple were usually accompanied by players upon the French horn. The approach from Vauxhall Stairs (not far from the present Vauxhall Bridge) was mean-intentionally, for after a shabby wicket gate and path, 
the visitor came suddenly into a blaze of glory, the boxes, the trim walks and hedges, the orchestra, the archways and colonnades making up ornamental grounds which must have surpassed even Ranelagh in attractiveness. Ever since the Restoration there had been gardens on the spot-New Spring Gardens, whither Londoners resorted to pick the pinks and hear the nightingales; but the Vauxhall of tradition and reputation was really inaugurated in I732, when Jonathan Tyers opened the relaid and remodelled grounds. There were pictures by Hogarth (who also designed the admission token) and Hayman, sculptures by Roubillac, music composed and conducted by Handel, and songs by all the principal singers of the day. The only drawback seems to have been the dearness and scantiness of the refreshments: it was said mockingly that a Vauxhall carver could cover the whole grounds-eleven or twelve acres-with slices from a single ham. Towards the end of the eighteenth century, when tight-rope performances and similar entertainments began to be given, the place grew rather less orderly and select-though it had always attracted both citizens and "persons of quality"; but the gardens continued to be popular, till at last -in I859-the ground was sold for building purposes, and the glades ceased to be either "lovely" or "tuneful," as the print of a song, "Farewell to Vauxhall," on the left-hand wall of this room, calls them.

Most of the other pictures here relate to the London Parks rather than to the pleasure gardens; 
and as they have, and have long had, a large share in the life of Londoners, it is well to give a brief account here of the two most famous. Hyde Park, the largest of the Parks, was originally the manor of Hyde, the property of the Abbey of Westminster. At the dissolution of the monasteries it became Crown property. Charles II. walled it in, and in his reign it became the fashionable promenade which it still is. Like St. James's Park, it was the scene of many duels; and in it were celebrated many important events-George III's jubilee, for instance, and the peace of $18 \mathrm{I}_{4}$, when, as a print here shows, there were fireships on the Serpentine. The Great Exhibition of $185 \mathrm{I}$ was also held here, as has been said (p. I75).

St. James's Park, however, has the more interesting associations. It was first enclosed by Henry VIII ; Charles II laid it out anew, formed the lake, and stocked it with waterfowl. He loved to walk here, and this is a grief that befell him in the Park:

Lost, in St. James's Park, Nov. 16, 1671 . . . a little Spaniel dog of his Royal Highness; he will answer to the name Towser, he is liver coloured and white spotted, his legs speckled with liver colour and white, with long hair growing upon his hind legs, long ears, and his underlip a little hanging; if any can give notice of him, they shall have $£_{5}$ for their pains.

That was not the only time the King lost one of the pretty little spaniels named after him. The Park, still in many ways the most individual and delightful in London, was gay all through his reign, and was, like Hyde Park, a fashionable promenade for long 
after. Here, too, were fought many duels (in spite of prohibition): here were cockfights, commemorated in Cockpit Alley and Birdcage Walk: here the cavaliers played Pall Mall (p. I29) : here were the cows whose milk old women sold on the spot till a few years ago; here the Gunnings were mobbed by a crowd of inquisitive Londoners, then, as ever, full of "ardour in running after sights and monsters" -not that those ladies, the most famous beauties of the eighteenth century, could exactly be called monsters. And here, too, in all ages, the waterfowl have given pleasure to Londoners. It is worth while to quote Evelyn's description of them as they were in 1665 : in most ways his words would almost fit the Park of to-day. "I went to St. James's Park, where I saw various animals and examined the throat of the onocrotalus, or pelican, a fowl between a stork and a swan; a melancholy water-fowl, brought from Astrachan by the Russian Ambassador. . . Here also was a small water-fowl, not bigger than a moorhen, that went almost quite erect, like the penguin of America; it would eat as much fish as its whole body weighed; I never saw so unsatiable a devourer, yet the body did not appear to swell the bigger. The Solan geese here are also great devourers, and are said soon to exhaust all the fish in a pond. Here was a curious sort of poultry, not much exceeding the size of a tame pigeon, with legs so short as their crops seemed to touch the earth; a milk-white raven; a stork, which was a rarity at this season [February] seeing he was loose, and could fly loftily; 
two Balearic cranes, one of which having had one of his legs broken, and cut off above the knee, had a wooden leg and thigh, with a joint so accurately made that the creature could walk and use it as well as if it had been natural; it was made by a soldier. The park was at this time stored with numerous flocks of several sorts of ordinary and extraordinary wild fowl, breeding about the Decoy. . . . There were also deer of several countries, white, spotted like leopards; antelopes, an elk, red deer, roebucks, stags, Guinea goats, Arabian sheep, etc. There were withy pots, or nests, for the wild fowl to lay their eggs in, a little above the surface of the water." There were also, rather over a century later, " the Queen's Animals"-various creatures somewhat inconveniently presented to Queen Charlotte: among them were elephants and a "piebald ass" -a zebra.

Many rejoicings have taken place in St. James's Park, as in Hyde Park. The most notable commemorated here were over the Peace of I748, when six thousand rockets were fired at once, and a set piece showed three suns of fire and twelve fiery trees. In I8I4, too, there were demonstrations over another peace, and a Temple of Concord was set up in the Green Park-rather prematurely, for I8I5 saw Napoleon as active and menacing as ever.

The first home of the London Museum must also be mentioned here. Kensington Palace was built in the seventeenth century as a private house, and sold to William III, who died there: with it went the Gardens, which now are a park 
continuing Hyde Park. George I and Queen Caroline, wife of George II, designed most of the present arrangement of the Gardens. The Palace is Crown property and has been used as a royal residence until recent times: rooms in it are still occupied, as at Hampton Court, by privileged persons. Queen Victoria was born there, and held her first council there in 1837 : and there, too, Queen Mary was born.

The next section of the Basement, another small room, is mainly filled with the large model of the Tower already mentioned. At the door is the handsome pilaster of the high altar of the Sardinia Chapel, the chapel attached to the Sardinian Embassy on the west side of Lincoln's Inn Fields. It was demolished in Igio.

Here also is a fine collection of insurance plates, such as may be seen on many old houses of the eighteenth and early nineteenth centuries all over England. These plates were not merely evidence of the issue of an insurance policy by the company for which they stand; they were also guides to the firemen, who at that period were maintained by the various insurance companies, each having its own organisation. The "Sun" men would single out a "Sun "house for their work, the "Phœnix". men a "Phœnix," and so on. The London Salvage Corps, though it attends all fires impartially, is still maintained (jointly) by the insurance companies, who naturally desire to prevent more loss than can be helped.

In the next room is the Stuart Parlour, already 
described (see p. II2, and Frontispiece). Here also are other architectural remains, among them a fine piece of panelling of the popular "folded linen" pattern. A small case shows us what burial in the ground means to many such objects as the Museum possesses : it contains shoes, pottery and other things just as they were dug up, before being cleaned. Close by are the Great Harry timbers (see p. 102); a model of Isaak Walton's beautiful house, which formerly stood at the corner of Fleet Street and Chancery Lane-here that delightful angler carried on his business as a hosier from I629 to I643; a cast of the ceiling of Sir Paul Pindar's lovely mansion in Bishopsgate Street, the front of which is reproduced at the Victoria and Albert Museum-it must have been in some such building as this that Sir Thomas Gresham, close by, feasted Queen Elizabeth (see p. 98); and a model of Hogarth House, Chiswick, which happily still stands. In that house Hogarth painted those terrible pictures of his brutal century. There he played ninepins or petted his bullfinch Dick. There Wilkes or Fielding smoked and talked with the artist.

Most of the objects in the next room explain themselves, and do not call for comment. The Stuart rocking-horse is there (see p. I30). The hand-painted "Chinese" wallpaper and the huge tea-canister take us back once more to the London of Chinese fashions. In this room is the most noticeable relic of Charles Dickens possessed as yet by the Museum-a chair in which he once sat to be photo- 
graphed. Dickens, like Johnson, was not born in London: but like Johnson also, he was a true and great Londoner. It is a wonderful thing, not always realised even by those who write about London, that in spite of all the City's distractions and disadvantage, by far the greater part of all that is best and noblest in English literature was actually produced in London; while of writers whose life and work was peculiarly identified with London-like Chaucer, Shakespeare, Jonson, Milton, Dryden, Addison, Steele, Johnson, Fielding, Richardson, Goldsmith, Sheridan, Lamb, Dickens, Thackeray, to name only a few-no city in the world can show a longer or prouder record.

The small room which follows contains more architectural details, all excellently worthy of preservation. In the windows are two interesting contrasts in children's costume-of I 837 and I887in which the later period can hardly be said to have the advantage. On the right is an ingenious balcony, the central part of which, when a staple is loosened, lets down in the form of a ladder, as a fire-escape.

We come now to the grimmest part of the Museum -remains of which London has no great reason to feel proud, the prison relics. The very doorway through which we enter this section is from a jail -the Neptune Street prison for poor debtors. It was also, according to Mr. G. R. Sims, known as The Sly House, because many prisoners who entered it were never seen to leave it : they had been taken 
away, by an underground passage, to the Docks, and so to a convict ship, to be borne far away to the convict stations of Australia. Through the door is one of the cells, fitted with ghastly figures of prisoners. Poor debtors-" whose only crime was poverty," and who, by being imprisoned, usually lost all chance of earning a living to pay their debts -were treated in the eighteenth and early nineteenth centuries with an inhumanity which even the vilest criminals could hardly deserve. On entry into jail, the senior prisoners extorted from them whatever money they had, by way of footing or "garnish " : if they had no money, their clothes were taken from them. The food issued to them was insufficient to maintain life, and even the money they were allowed to collect by sitting in a cage in the prison walls and rattling a money-box dolefully at passers-by, with the cry of "Pity the poor debtors," did not avail to ward off the most terrible privations. Darkness, hunger, damp, cold, disease, despairthat was the fate of the poor who got into debt.

Dickens, in The Pickwick Papcrs, draws a terrible picture of imprisonment for debt as it was under the Regency. It was infinitely worse fifty years earlier, before the noble labours of John Howard (I726-90) and Elizabeth Fry (I780-I 845) had done much to change the condition of most of our prisons.

But if the poor debtor was deep in misery, the real criminal was still deeper. In the dark second cell, on the walls, are grisly reminders of what torture 
meant-hand-crushers and an iron scourge, and a scold's bridle or a terrific gag for shrewish women. Here too is an oak table with initials cut in its worn surface-the initials of men to whom the simplest of rational occupations almost meant happiness.

Opening out of this cell is the room of Newgate relics. That grim prison was pulled down in $\mathrm{rgO2}$, and the present Central Criminal Court was opened on the site three years later. The "Old Bailey," as the prison was called, stood on the site of one of the gates in London Wall, most of which were used at different periods as prisons. The grim-looking building, which many Londoners remember, was erected in $I 770$, and from $I 783$ to 1868 executions were held in public outside it : before 1783 they were held at Tyburn (roughly, where the Marble Arch is now-see p. I4). It was said that these public spectacles acted as a terrible warning, and prevented crime: but all the evidence goes to show that they had no preventive effect, while they were unspeakably degrading and brutalising to the crowds of men, women, and even children who gathered to them as if to a festival. From I 868 to I902 prisoners were executed inside the jail : the straps used for the last execution are on the right hand of the entrance door.

It was customary for "last dying confessions" of prisoners (death was long the penalty for even trivial felonies) to be crudely printed and sold in the streets on the day of execution. They were doubtless seldom written by the prisoners, who 
often would be incapable of even such poor literary work as this of 1833 :

"Come all young men of London town,

A warning take by me,

'Tis my awful doom to die,

Upon a fatal tree,

For a Burglary in Bartlett's Buildings,

It's true what I relate,

That's brought me to grief and scorn

And to this wretched state."

There are many of these dreadful broadsides in the room: they give a terribly close picture of the realities of crime.

Certain of the more famous criminals are recalled more individually. There is on the left a painting of the last scene in the life of Henry Fauntleroy, a famous forger, whose exploits and death are sufficiently described in the label on the picture. In the left-hand window are likenesses of Elizabeth Brownrigg, a vile creature who beat a girl apprentice to death, and Simon, Lord Fraser of Lovat, a more romantic offender-merely a Jacobite conspirator who was beheaded on Tower Hill in I747: this is said to be the last beheading in England. In a case on the right is the rummer, or drinking-goblet, of Dick Turpin, engraved with his false name of Reader, and formerly kept for his use at the "White Swan," Whitechapel. The best epitaph on Turpin would perhaps be the curt opening of the Dictionary of National Biography's account of him-" Turpin, Richard (I706-39), robber. . . ." He was a vile housebreaker and 


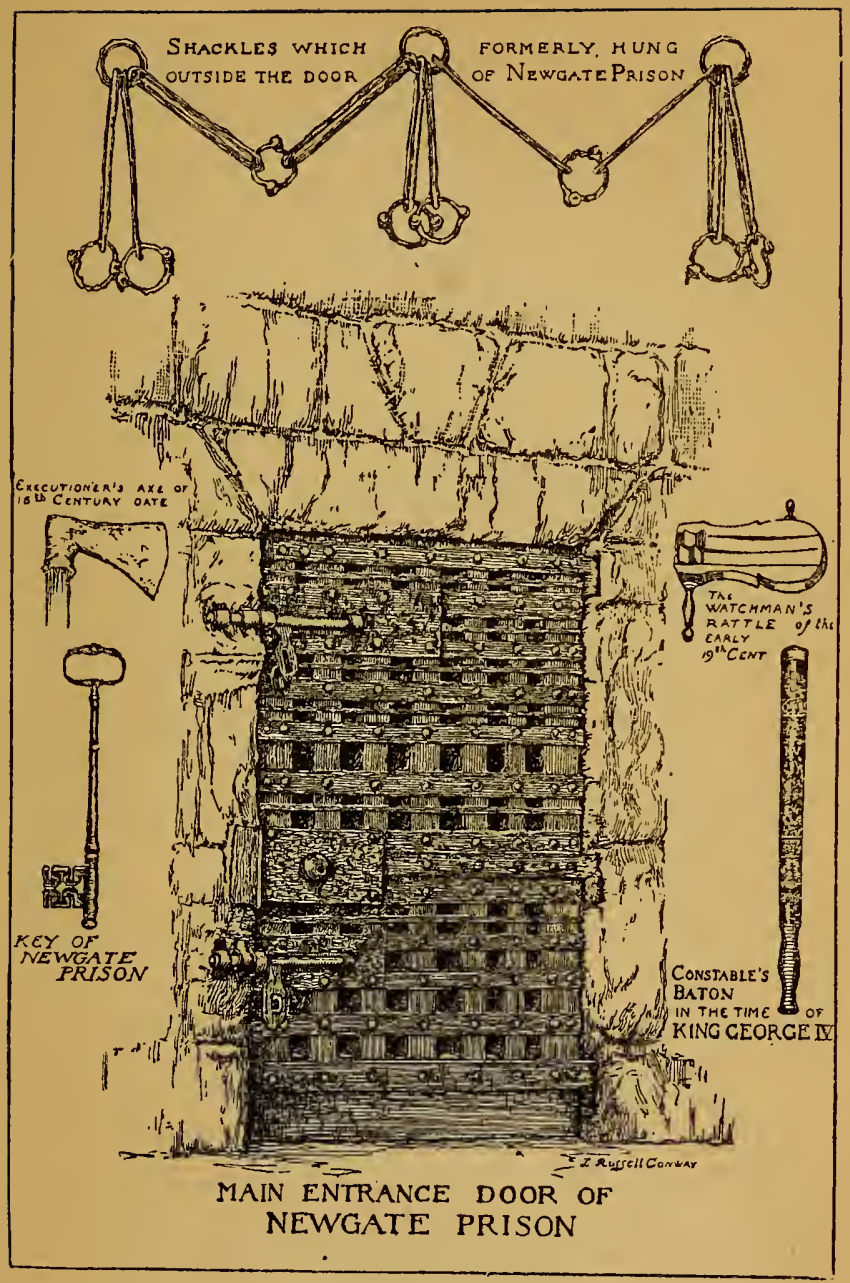

PRISON RELICS 

highwayman, with nothing romantic or heroic about him-not even his ride to York, which never took place in reality: some such ride may once have been accomplished, but the story of it is older than Turpin's day. He was hanged for horse-stealing, and "confessed to one murder and several atrocious robberies." Tom King, whose fetters are at the other end of the room, was for a time his confederate, and was accidentally shot by Turpin in Whitechapel, in an attempt to get rid of a constable.

Joanna Southcott has hardly earned her place in this gallery of criminals. This poor woman was a domestic servant, who from I792 onwards believed herself able to prophesy-and some of her prophecies certainly "came true." She also claimed that she was to be the mother of a second Messiah. She had a considerable following, but except for the mischief caused by hysterical false doctrines, she did no great harm, and her personal character was blameless. She died in I8I4, in London, and is little remembered now except by medical men, who find in her case striking instances of the power of mental aberration and delusion.

Jack Sheppard, like Turpin, has been glorified by an eminent novelist : it was as an antidote to such works as Harrison Ainsworth's that Thackeray wrote his terrible novel Catherine. There is a sketch of Sheppard drawn from life by Sir James Thornhill, with the much more flattering print that was subsequently issued. Jack Sheppard was the son of a respectable Spitalfields carpenter, and began his criminal career after running away from a master 
who ill-used him. He devoted himself to burglary from a very early period of his life, and was so ingenious in his methods of escaping from prison that he seldom was long confined. He once got out of Newgate in spite of his being loaded with irons which were locked to a staple in the ground : he procured somehow a crooked nail, picked the lock, climbed the chimney, entered other rooms, including the chapel, opened four doors with a spike from the chapel door, reached the roof, and thence, by means of a blanket which he had dragged with him, let himself down to the garret of a neighbouring house, and so into the street. All this time he was wearing fetters.

He even made desperate plans to escape after being condemned to death; he hoped to cut his bonds in the cart which carried him to the execution place at Tyburn, and so leap into the crowd: he had won a certain popularity, and he expected to be helped in such a case. But he was too closely watched, and was duly hanged-as deservedly, if hanging was a suitable penalty for robbery, as any criminal in England.

He had peculiarly small hands and limbs, as Thornhill's sketch shows; and he was thus enabled to free himself from fetters which would have secured more largely built men.

Other relics in this room are part of a set of "chains," or an iron framework, for hanging in chains (the body of the criminal was left to decay in this awful position: Jerry Abershaw, from whose 
skeleton this specimen was taken, was a notorious highwayman); a basin from the condemned cell; a handcuff with a screw, to fasten an idle apprentice to his chair (a punishment which seems almost amusing after the other penalties suggested here); a tall hat of the old police uniform, so common in the early pages of Punch; watchmen's rattlesthe watchmen were the very inefficient street patrol of the eighteenth century (an old watchhouse still stands in Giltspur Street, near Newgate): staves and warrants and badges of special constables, sworn at times of disturbance, as in $I 848$, or for particular great occasions like the I887 Jubilee: the magistrate's chair from Wellclose Prison; and an alarm gong, handcuffs, fetters, keys, from Newgate.

Prisons are a necessity, and there is room for many reasonable differences of opinion as to how they should be managed, and with what ideals. But there can be nothing but thankfulness that the bad old times are gone for good, when death was a spectacle, and disease so deeply rooted in the awful jails that judges were guarded against jail-fever by bunches of aromatic herbs, and John Howard himself died of the fever - in Russia, it is true; but England was no safer. When Newgate Prison was pulled down, it is said, there was still in its very fabric enough malignant infection to set up curious feverish colds in the households in Amen Court close by, where the Canons of St. Paul's live. And disease was not the only enemy. 
Even as late as $185^{\circ}$ the prison doctor was wont to carry a life-preserver (one is shown in the lefthand window case), in case of attack by his patients. The system not merely kept criminals, it made them.

Outside this room we come once more to gentler things-pictures of Old London, tradesmen's noteheadings and accounts, graceful tablets, and decorations from street walls and vanished houses; and thus at last we return to the main hall of the Museum, passing, in the last corridor, pictures of eminent Victorian Londoners by the well-known caricaturist, "Spy" (Leslie Ward).

So we have reached the last stage, for the present, of this fine Museum. Outside Lancaster House, in Stable Yard, policemen will be keeping cabs and carriages out of the royal precincts of the old Tudor place of St. James's. Within that palace live functionaries whose offices go back infinitely far in the history of England and even of Europe. In the Green Park, a few yards away, given to London by her most dissolute king, the quiet sheep are feeding within a stone's throw of noisy Piccadilly. The monument of a great Queen gleams in the Mall in front of her grandson's palace; at the other end of the broad way stand up the thin wires that speak through the ether to the King's Armadas on many seas ; and past the trees of St. James's Park, under which, in the sandpit, to-morrow's Londoners are playing, rise the towers of the most ancient and honourable of Parliaments, and the most venerable 
of all churches. In London the past is always present, the future always close. The galleries of the London Museum tell the story of centuries; but every street of London is built upon the centuries, and speaks with their voice, if we could but hear it. The Museum interprets for us their speech, lights up their life, gives resonance and pomp and inspiration to their language that is not dead, but only sleepeth. He is a bad Londoner who has not learnt that mother tongue.

Does it seem, to men weary of to-day's turmoil, that we Londoners have forgotten our inheritance? Perhaps it does; and yet the company of our dead will not be dishonoured by those who have joined it in this twentieth century after Christ. Londoners are as ready as ever to serve their country in war and in peace ; most of all, perhaps, in peace, where the test of life is harder than the test of death. Go to the little cloister behind the Post Office, and see how gaily they meet that last adversary. Go to Bethnal Green, and see with what courage they face the enemy who is always with us. The men whose dumb hopes and lost sorrows we view in Lancaster House, in the little stones and odds and ends of a museum, thought no more than men today of their own heroism, realised no more than men to-day their own unformulated ideals, remembered no more than men to-day that past that now seems unforgettable. If we knew more, if our faith were stronger, doubtless London would be more radiant in the eye of heaven. But even if we live only in the things of now, we still are in a city not built 
with hands, heirs to a kingdom that has no name and no boundaries; for we are lords of our own hopes, and we build London willy-nilly, as our fathers built it-citizens, they and we and those to come, of no mean city. 


\section{INDEX}

Abbey, E. A., I 80 ; collection of costumes, $180 \mathrm{sqq}$.

- Mrs. E. A., I8o

Abershaw, Jerry, 242

"Adam and Eve, The," 226

Addison, 79, I63, I64; quoted, 162, 197, 199-200. See also Spectator, The

Agincourt, 55

Ainsworth, W. Harrison, I3I, $24 \mathrm{I}$

Albemarle, Lord, I I9

Albert, Prince, his uniforms, 2 IO

- Memorial, I75

Aldersgate Street, 3 I

Aldgate, 56

Aldwych, 218; Danes at, 38, $4^{6}$

Alexandra, Queen, 2 ro ; loan exhibits, 73

Alfred the Great, " restores" London, 35; at Athelney, 37 ; his jewel, 36-7

Allectus, I 9, 22, 29

Almack's, 225

"Alsatia" (Whitefriars), I03

Altar, Roman, 27

Amelia, Princess, 208

Amen Court, 243

Amphora, Roman, I8, 24

Ampulla, 55-6

"Angel gold," I24

Anglo-Saxon Chronicle, quoted,

“Animal comedians," I 5I, 207, 226
Anne, Queen, 78-9, I 79 ; period of, see chapters VIII and IX Apprentices, 72 ; riots, 95-7 ; in trained bands, I22; costume, 187

Archers, English, 48-52, 54, 87

Archery practice, $54,95,123$

Arlington, Lord, $22 \mathrm{I}$

Armada, the Spanish, I 8I

Armour, mediæval, 48-52 ; later, I 89-190

Army uniform, I89-190

Art Workers' Guild, 86

Artillery Ground, 226

Arts and Crafts Society, 86

Augulus, Bishop, 29

Augusta, Colonia (London), 30

Augustine, St., 35

Axes, flint, $\mathrm{I}, 7,8$; bronze, $\mathrm{I} 2$; mediæval, $5 \mathrm{I}$; toy, 39

BADGE, of Bedlam Beadle, 73

- Doggett's, 75

Bagnigge Wells, 227

Balance. See Steelyard

Balloons, 226

Balmes, I 5

Bank of England, 40, I77

Bankside, I03, I8I

Banqueting Hall, Whitehall, II 3

Barber's bowl, r27, I4I

Barbican, $3 \mathrm{I}$

Bardell, Mrs., I 84

Barking, I 36 ; fort at, 9

Barrie, Sir J. M., quoted, 85 
Barry, Sir C., viii

"Bastard sword," 48-5I

Bath, order of the, 73

Battersea, finds at, Io

- enamels, I 46-7

Battle-axes, mediæval, 5 I

Baulmes, II 5

Baynard Castle, 6o, I04, 217

Bazalgette, Sir J., I7 I

Beadle, Bethlehem Hospital,

" Bedlam." See Bethlehem

Hospital

Belgravia, 167,226

"Belinda," 160

Bell, Celtic, 34-6

Bellarmine, Cardinal, 93-4

"Bellarmines," 93-4, I I I

"Benevolence" to Charles I, I 6

Benoist, 136

Bermondsey, I 44

Bethlehem Hospital, 62, 73-4, I 55, 227

Bible chain, 88

Bicycles, 2I3-4

Birdcage Walk, 23 I

Bishops of London, 29, 35

Bishopsgate, 73, 99

- Street, 98

Blackfriars, $60, \mathrm{IO}_{4}$

- Bridge, 30, I04, I28, 166-7

Blackwall, I03

Blake, Admiral, I 36

Bleeding, I 27

Blessington, Lady, I86-7, I94

"Blue-Coat School." See Christ's Hospital

"Blue Coat" (school costume), $74-5$, I 87

Boadicea, 19, 27-9

Boat, prehistoric, I2-3, 218 ; Roman, 20-3

Bobbins, $2 I_{4}$

Boleyn, Anne, I 70

Bone skates, 127

Bonnets, I96, 209

Books, 90. See also Printing
Boots, IIo, I9I-3. See also

Shoes, Clogs

Bos primigenius, 4

Bos priscus, 4

Bosses, architectural, 59

Boswell, I 85-6

Böttger, I39

Bottle, Roman glass, 18

Bow (and arrow), 9, I44. See also under Archers, Archery, Crossbow

- porcelain, I 40, I 53-4, I 59

Bracer, archer's, 95

Brandon (executioner), II 8

Brentford, ford at, 20, 23

Bridewell Palace, 104-5

Bristol, I09

British Museum, I8, 20I-2

Broad Street, I6 7

Bromley, I03

Bronze, first use of, 9

Broseley pipes, 109

Brougham, 184

Brownrigg, Elizabeth, $23^{8}$

Buckingham House, $22 \mathrm{I}$

- Palace, vii, 221

Buclsles (shoe and knee), I92-3

Bullock's Museum, 223

Burbage, I8I

Byron, 187

CABS, 185

Cade, Jack, 52-3, 6 I

Cæsar, Julius, I2, I6-7, 20, 23

Camps, Celtic, 16 ; Roman, 16

Camulodunum, 28

Candles and candlesticks, 69-7I

Canes, I47, 195

Cannon Street, 29

Canoe, dug-out, I 2-3

Canterbury Tales, The, 55-6, 68

Canute, 37,46

Caps, I 88-9; flat Tudor, 95, 97. See also Headgear

Carausius, 19, 22-3

Carlton House, 168-9

Carmelites, 60 
Caroline, Queen, 233

Castlemaine, Lady, 94

Catalini, Madame, 206

Catherine, $24 \mathrm{I}$

Caudle cups, I 42

Cave-bears, 4

Cave-lions, 4

Caxton, 55

Celts in London, 10-4, 16-7, $18-9,23,24,25,29,32$, $34-6$

Central Criminal Court, 237

Chained Bibles, 88

Chain-mail, 5I, 87

Chains, hanging in, 242-3

Chairmen, I 85

Chalybeate springs, $167,207-8$, 227

Chapes, $5 \mathrm{I}$

Charing Cross, II 3

- Road, 167

Charles I, bust of, Ir9; exactions, II6-7; execution, II4. II 7-8; plate melted for, $67-8$; relations with the City, $x, 116-8$, I23, I 7 I

Charles II, 94, I32, I93, $230 s q q$. ; extravagance, 126 , I 36-7 ; in St. James's Park, I 29-30 ; portraits of, I42 ; restoration, I22 ; touching for the evil, 124

Charlotte, Qucen, 208, 232

Charms, 90

Charters of London, 45-6, 54

Chatham, naval disaster at, I $36-7$

Chaucer, 55-6; quoted, 55, 68

Cheapside, $63,79-80,96,98$; model of, I04

Chelchith, 36

Chelsea, 36, 59, I67, 201, 208, 225

Chelsea porcelain, I40, I48sqq.

"Chelsea-Derby," I52

Chess, chessmen, 90

Chest, Stuart, 107

Cheyne Walk, 201
"Chicken"gloves," 194

Children's costume, 234

Child's Coffee-house, 199-200

China. See Porcelain

Chinese productions, I 53, I 55

Chivalry, age of, 48-52

Christianity in London, early, 29-30, 35, 40, 42-3

Christ's Hospital, 59, 74-5, I73

Chronicle of England, The, 48

Cistern, lead, 213

"City Road," on frozen Thames, 128

Clarence, Duke of, 2 I I

"Clarence" (carriage), I 84

Claudius Cæsar, I9

Clerical costume, I 8 th century, I 88

Clerkenwell, I44, I67, 207-8, 227

Clockmakers' Company, 158

Clocks, I 43, I 56-8, I60

Clogs, 59

Cloisonné work, 37

Clubs (staves), 'prentices', 95-7

Coaches, coaching, 222

Coats, men's, 190, 198

Cockfighting, 54, 23 I

Cockpit Alley, $23 \mathrm{I}$

Coffee, use of, 78-9

Coffee-houses, 5I, 78-9, I 59, I98 $s q q$.

Coffee-pots, 78-9

Coif, Sergeants of the, 62

Coins (see also Currency), I9, $22,23,30$, IIO

Colchester, 28

Coleridge, 75

Colet, John, 63

Collingwood, Lord, 77

Colonia Augusta (London), 30

Combs, 40, 87, 110

Commons, House of, frescoes, 87

" Commune" of London, 46

Companies, the City, 5I, 67, $7 \mathrm{I}-2,83, \mathrm{I} 62$

Conduits, in Cheapside, ro 4 
Constables, special, 243 ; in plague time, ror-2; with cressets, 132

Constantine, I9, 30

Constantius Chlorus, 22

"Copperplate handwriting," I73

Corbels, II 2

Cornhill, 96

Coronations, in London, 46,54 , I00, I24-5, I35, I 79, 2 I I-2, 217

Costrel, 56

Costume (outside chapter XI.), apprentices', 95, 97; 'Tudor, 95, 97 ; Stuart, 108, II 2

Counters (gaming), 225

County Hall, 20

Covent Garden, I 44, I64

- Garden Theatre, 76-7, 205-6

Cradle, fifteenth century, 87

Crannogs, 7

Crawfurd, Lord, 6 I

Crayford, battle of, 35

Creçy, 55

Cremorne Gardens, 208

Cressets, 7I, I32

Cricket, 223-4

"Cries of London, The," $2 \mathrm{r}_{4-}$ 217

Cripplegate, 28

Crockford's, 225

Cromwell, Oliver, relics of, II8-II9; character, II8; death-mask, II 8 ; portraits, I1 8 ; welcomed in London, I 20, I 70 ; sea-power of, I36

- Richard, documents of, I 19

Crosby Hall, 59, 6I

Cross, in Cheapside, $\mathrm{IO}_{4}$

Crossbow, 52, 144

Crosses, mortuary, 59

Crowther, John, I 53

Crutched Friars, 88

Crystal Palace, the, I 75

Cups, fuddling, I Io ; gilt, 75 ; loving, 67 , I I I ; silver, 66-7; silver-gilt, I 35 ; skull, 38 ; Tudor, 90 Currency bars, Io-I I

Curtain Theatre, 77

“Dancing Lesson, The," I 4952

Danes in London, 37-40

Debtors' prisons, 236

Deæ Matres, 24

Defoe, I3I-2, 164

Delft ware, 88,89 , I 40-I , I 72-3

See also Lambeth Delft

Deptford, I00, I02

Derby, 109

Dettingen, r 84

Dexios, memorial tablet, 25

Dice, 225

Dickens, quoted, I73, r84, I93, 222, 234-5, 236; relics of, 174

Diocletian, 22

"Dog and Duck, The," 227

Doggett, Thomas, 75

Doggett's coat and badge, 75

Dolls, 160-2; Queen Victoria's, 209

Doll's House, 160-2

Dominicans, 59-60

Doublet, Tudor, 95, 97

Drake, I00, I02

Dresden porcelain, I 40

Drury Lane Theatre, viii, $76-7, \mathrm{I} 44,205$

Duels, 230, $23 \mathrm{I}$

Duesbury, William, I52-4

"Dug-out" canoe, 12-3, 218

Duke's Theatre, The, 76

Dutch at Chatham, I 36-7

- East India merchants, $\mathbf{I}_{40}$

- tiles, I35

Dwight, John (maker of Fulham ware), I 37, I 39, I 4I-2, I 72

EALING, I66

Earthworks. See Camps

East Saxons, 32 
Edmund Ironside, 46

Edward the Confessor, 43-4, 45,123

- I, 54, 104

- II, 54, 6I

- III, 54

- VI, 74, I05

- VII, I79, 2 I0

Egyptian Hall, 223

Eiffel Tower, 94

Eleanor, Queen, I 04, I I 3

Elizabeth, Queen, 89, 90, I8I, 210

Enamel, Battersea, I 46 ; cloisonné (cell), 37 ; Limoges, 42

English Costume, 190

Escapement (of a watch), I 57

Essex, 32, 43

Ethelbert, 35, 42

Evelyn, John, I35; quoted, 74, I 24, I 28-9, I 36, 23 I-2

"Evil, the King's," I23-4

Ewer, bronze, 59

Exchange, the Royal, 97-9, I05, I62, I70

Executions, at Newgate, 237; at Tower Hill, IOO-I; at Tyburn, 237

Exeter, I09

- Change, 223

- Hall, 223

Exhibition, the Great (of $185 \mathrm{I}$ ), I 75, 209, 230

Fairfax, General, II9, I89

Fairy-tales, I 50-I

Falconer, Thomas, 63

"Falls," I90

Fans, I94-5

Farthingale, I90

Farthings, I Io

Fellowship badge, 223

Fermor, Mrs. Arabella, I60

Fielding, 234

Filby, John, I 86

Finsbury, 226

Fire, the Great, 43, 80, 99, I32-5, I 7 I, I93
Firearms, 196-7

Fire-escape, balcony, 235

Fitzmary, Simon, 62

Flask (ampulla), 55-6

Fleet (river), 14, I04, I05, I67; model of mouth, I04. See also Holbourne river

- Street, 6o, 62, 98

Flemings, potters at Norwich, 93

Flesh-hooks, 55

Flint and steel, 70-I

Flute, Roman, 25

Football, 54

Footpads, I 79

Forks, 68-9

Fox, Rev. George, 224

France (Celtic), I 7

Franciscans, 60

Freeport, Sir Andrew, I62

Frost Fairs, 61, 127-9

Froude, quoted, $7 \mathrm{I}-2$

Fry, Elizabeth, 236

- Thomas, 153

Fulham, 38, 226

- pottery. See Dwight, John

Fuller, John, 98

Funeral pomp, I 74

Fusee (of a watch), I 57

GAMBLING, 225

Games, moral, 224-5 ; outdoor, 54 , I 29 ; with counters, 39-40

Gardening, I Io

Garibaldi, I 5

Garraway's Coffee-house, I 59

Garrick, 186, 203-5

Garter, Order of the, 73,187 , 2 II

Gas, introduction of, 7 I

Gauntlet, archer's, 87

George I, I 79, 233

- II, I 79, I 84

- III, I79, 22I, 230

- IV, 66, 75, I 79, 22I, 225, 228 ; festivities on accession to Regency, I68-9 
George V, I 79; coronation robe, ix, 2 I I -2 ; loan exhibits by, $87,210-1$

- St., Guild of, 123

German merchants in London, 99

- porcelain, I40

- stone ware, 142

Gibbs (architect), I64

Giltspur Street, I 32

Gipcier, gipsire, $5 \mathrm{I}, 87-8$

Girdle chains, 90

Glass, Roman, I 7-8, 25 ; Venetian, 88-9; English, 88-9, 90; Restoration, 127 , I 35

Glastonbury, lake-dwellings, 7

Glaze (on pottery), 44, 59, 142

Globe Theatre, 76

Gloves, 193-4 ; of Lady Blessington, 186-7; Stuart, 108; Tudor, 90

Gog and Magog, 99

Golden Hind, The, Ioo

Goldsmith, Oliver, I88, 204 ; his coat, I 85-6

Goldsmiths' shops, 79-80

Gomme, Sir L., quoted, 30, 102-3

Gorgets, I 89

Gouyn, Charles, 148

Graham, George, I 58

Grasshopper, weathercock of Exchange, 99

Gray's Inn Lane, 5

Great Harry, The, timbers of, I02-3, 234

Green Park, I4, 232

Gresham, Sir T., 89, 97-9, 105, 239

Grey, Lady Jane, $\mathrm{I} 7 \mathrm{I}$

"Greybeards " (jugs), 93-4

Greyfriars, 59-60, 74

Grimaldi, 207

"Group within a boscage," I 49-52

Guild of St. George, the, 123

Guildhall, the, $98,170-1$

- Museum, 38, 42, 158
Gun, Stuart, 108

Gundulf, 43

Gunnings, the, $23 \mathrm{I}$

Gurney, Goldsworthy, 178

Gwynne, Nell, 165, 227

HACKNEY coaches, 185

Hadrian, head of, I8-9 ; coin of, I9

Hair-dressing (see also Wigs), x97-8, 227

Hallstaitt period, 10-I

Hamme, J. A. van, I $40-I$

Hammersmith Bridge, I 74

Hampstead, 95, 167

Hand-crushers, 237

Handcuffs, 243

Handel, 229

Hansom, Joseph, 184

Hanway, Jonas, 195, 196

Harcourt, Rt. Hon. L., viii, 80

Harpoon, palæolithic, 4

Hastings, Warren, I 70

Hats, 188-9, I95-6 ; cocked, I89; tall, I96

Hawkins, Miss, quoted, 205

Haymarket theatres, 76-7

Headgear, I88-9, I 90, I95-6

Heath, John, I 54

Hele, Peter, $156-7$

Helmet-makers, 5 I

Helmets, $5 \mathrm{I}$; fire, 132

Hengist, 35

Henlein, Peter, $156-7$

Henry III, 43, 6 I

- VII, 123

- VIII, I05, Ir3, 230

Hertford, Marquis of, I69

Hetherington, John, 196

Heyleyn, Edward, I 53

Highgate, I4, I67

Highwaymen, 197,223

Hill, Dr. Birkbeck, quoted, I 86

- John, 226

His Majesty's Theatre, 76-7

Hogarth, William, $147-8,229$, 234 
Hogarth House, 234

Holborn, 103, I32, I67 ; monasteries in, $59-60$

- Bars, roo

- Hill, I67

- Viaduct, 59, r67, x78

Holbourne (river), I 4

Honourable Artillery Company, the, 123

Hoops, 198

Horseshoes, Roman, 27

"Horseless carriages," I 78, 223

Howard, John, 236, 243

Hoxton, 95, I03, II 5

Hunt, Leigh, 75

Hyæna, 5

Hyde, manor of, 230

- Park, I75, 230

- - Corner, 164, I66

IBERIANS, I 2, I 6

Ilford, 166

India-rubber dolls, first made, I62

Ingots, copper, ro

Inns, London, 56

Insurance plates, 233

Irish Dragoons' uniform, I 85

Islington, 95, I03, I 25

Italian statuary, 108

Italians in London, 88-9, 95-7

"JACK" (flag), 136

Jack-boots, I Io

" Jacks," leather, 94, I ro

Jackson, Mrs. Neville, I6I

Jail-fever, 243

James I, I09, I I I, I I3-4, I I 7, I 79, 221

- II, at Great Fire, I32 ; at Whitehall, II4, I 43; touching for the evil, 124: patron of art, I35-6; restores Navy, 136-7

Janssen, II 5
Janssen, Stephen (enameller), 146

Jerningham Collection, the, 22I, $223 s q q$.

Joicey, Mr. J. G., gifts by, I46, I 80

Johnson, Dr., II3, I63, I85-6, 204,228

Jones, Inigo, I 13

Journal of the Plague Year, I 3 I-2

Jousts, at Westminster, 88 , roo

Jugs, "puzzle," I ro-r. See also "Jacks," Pottery, Glass

KEAN, 205, 207

Keep (of Tower), 43-4

Keeper of London Museum, viii, xiv

Kelt (axes), r2

Kelts (race). See Celts

Kemble (actor), 205-6

Kempenfelt, 2 I I

Kennington, 167

Kensington Gardens, 232-3

- Palace, 209, 232-3; home of Museum, viii

Kent, Duke of, his medicine chest, 209

Kew Palace, 208

King, Tom, 24I

" King's Evil, the," I23-4

King's Road, Chelsea, 225-6

Kingsway, 167, 21 8

Knights, methods of fighting, 48-52

Knives, 5I, 87, I09, I25

Konal (Dane), 38

LACE, I 91,214

Laffitte, Jacques, I77

Lake-dwellings, 7

Laking, Sir G., viii, xiv

Lamb, Charles, 75 ; his handwriting, 173

Lambe, William, 98, 125

Lambeth, 36, 73 
Lambeth Delft, I39, I40-I

Lambhithe, 36

Lamb's Conduit Street, 125

Lamps. See Lights

Lancaster House, history, viiviii

Leadenhall Market, I4, 3 I

Leather barrels, 94

— jacks, 94

- trunk, I25

Lehzen, Baroness, 209

Letters, 126-7

Lever, Sir W., viii

Life Guards' breastplate, I9o

Life-preserver, 244

Lights and lighting, lamps, 23-4, 69-7I, IO9-IO, II2

Limoges enamel, 42

Lind, Jenny, 205

Lobated pommel (of sword), 40-I

Lombard Street, 2 I 7

London (name of), I I

- Bridge, 28, 3I, 38-9, I28, I66, 170, 217 ; history, and model of, 60-r, 103, $\mathrm{II}_{4}$; Nonsuch House on, 94

- County Council, 86

- Museum, foundation of, viii ; plan of arrangement, $x$

- Stone, 29, 53

- topography: Pre-Roman, I4-5; Roman, 30-I ; Saxon and Norman, 46-7; mediæval, 63-4; Tudor, 103-5 ; Stuart, 144

London Pleasure Gardens, 207

Longchamps, William, 46

Lord Mayor's Show, Ioo

Lord's cricket ground, 224

Lotteries, 225

Lovat, Lord Fraser of, 238

Lower Regent Street, I68

Lucas, Seymour, 18o ; collection of costumes, I So sqq.

Ludgate Circus, I 4

- Hill, 6o

Lunardi, Vincent, 226
M.C.C., 224

"Macaronis," 195, 197-8, 227

Macready, 204

Mammoths, 4,9

"Mansion of Happiness, The," 224

Marble Arch, I4, I66

"Marching Watch." the, I22-3

Mary I, Queen, Ioo

- Queen (consort of William III), hair of, 125

- Queen, 233

Matches, 70

Matilda, Empress, 46

May Day, Evil, 95-7

Mayfair, 144, 167

Mayor, Lord, 53-4, 62-3, II 5, I I, I 22 ; costume of, I 87

Maypole in Cornhill, the, 96

Maximian, 22

Mazer, 125-6

Medway, Dutch fleet in, 136

Merchants, London, wealth and munificence of, $6 \mathrm{I}-3$, $97-8,125$

Merchant Taylors' Company, I35

Metropolitan ware, I I 2

Middle Saxons, 38

Middlesex, $3^{8}$

Military costume, I 89-190

Milton, John, I20

Mirror, Stuart, 108

Mithras (worship), I 7-9

Modish, Lady Betty, I5I

Monasteries, London, 59-6o.

See also under names of various monastic orders

Money-boxes, 59

Monk, General, I 19

Montgolfier, 226

Monument, the, I 32

Moore, Mr. H. C., quoted, I 78

Moorfields, 73

Moorgate, 63

More, Thomas, r7o

Mortars, 25, 126

Mortlake, finds at, 34 
Motor omnibuses, 17

Mouse-trap, 2 I 4

Mulberry Garden, 22 I

Musket, invention of, I 44

Myddelton, Sir Hugh, I25

NAPOLEON I, I66, I82, 232

- II, visit to London, I 74

National Gallery, I68

Needles, I Io

Needlework, Stuart, 108

Nelson, 77, I 74

Neptune Street prison, 235

"New Bridge," I66-7

New Bridge Street, I66-7

" New Canton," I 53

- Inn, 218

- Oxford Street, I67

- River Company, 125

- Spring Gardens, 229

Newbury, II 7

Newgate (gate), 63

- prison, relics, 236 sqq.

Newgate Street, 28, 60, 132

Newington Butts, 144, 227

Newspapers, the first, 125

Newsum, Bartholomew, 158

Nonsuch, chest, 94

- House, 94

- Palace, 94

Norman, Dr. Philip, Io2

Normans in London, 4. $1-6$

Northumberland, Earl of, Ior

O.P. RIOTS, 205-6

Old Bailey, the, 237

Old St. Paul's, I3I

Omnès, 177

Omnibuses, history of, $175^{-8}$, I 84-5

Ommibuses and Cabs, 178

Orders-Bath, 73 ; Garter, 73, 211 ; Royal Victorian, 73; Victoria and Albert, 73

Oxford, $67-8$

- Street, 167
PAck, pedlar's, 90-2

Pack-horse road, 92 .

Paddington, 166,177

Pall Mall (game), 129, 223,

$23 I$

- (street), 7I, I68

Panelling, II 2, 234

Pantheon, the, 227

Parasols, 195

Parks, London, 223 sqq.

Paulinus, Suetonius, 28

Paxton, Sir J., I 75

Pedlar's pack, 90-2

Pelican, The, 102

Peninsular War, $183-4$

Penmanship at Christ's Hospital, r 73

Pentonville, 167

Pepys, Samuel, 74, I 37 ; quoted, 83, I29, I32, I 36

Perrault, I 50

Persian porcelain, $I_{42}$

Pett, shipbuilder, I 36-7

Pewter, 90, I27

Phelps, Samuel, 205, 208

Philip of Spain, roo

Philpot, John, 63

Phœnix Fire Office, 233

Pianos, 225

Piccadilly, I03, I44, 223

- Circus, 3

Pickpockets, 197

Pickwick Papers, The, 223

Pile-dwellings, 7

Pilgrims, pilgrimages, $55^{-6}$

Pimlico, 167, 226

Pindar, Sir Paul, his house, 234

Pins, Roman, 25, 26-7; Tudor, 90

Pipes, 109, 126, I27

"Pipes" (wig-curlers), 197

Pistols, 196-7

Pitt-Rivers, General, $4 \mathrm{I}$

Plague, the Great, 80, 130-2 ;

other outbreaks, IOI-2

- regulations, IOI-2

Planché, Andrew, 154

Plate, gold and silver, 66-8 
Plate-armour, 5I-2

Platters, 89

Plautius, Aulus, 28

Plume, Sir, I $_{5} \mathrm{I}$

Pocahontas, 217

"Pocket-pistols," 172

Pole-axes, $5 \mathrm{I}$

Poleyns, I9I

Pommel of sword, lobated, 40-I

Ponsonby, Sir H., 209

Pope, Alexander, his " grotto," 163-4; quoted, 79, I5I, I60, 204

Poplar, xo3

Porcelain, manufactured in England, $\mathbf{1}_{4} 6-7$; method of production, I $39, \quad \mathbf{I}_{72}$; Chinese origin, $\mathrm{x}_{4}^{\circ}$; Persian, I 42

Post Office, General, 28, 59

Posts, postal service, I 26-7

Pottery, prehistoric, 5, 9; Norman, $42-5$; Roman, $17-8$, 23-4 ; Tudor, 93-4 ; Stuart, II 2; importance of, $42-5$; beginnings of English industry, $\mathrm{x} 37 \mathrm{sqq}$.

Poultney, Sir J., 62-3

Powder tester, 197

'Prentices. See Apprentices

Prickets, 70-I

Printing, invention of, 48,55 ; - specimens of later, $88,124-5$

Prior, Matthew, 164

Prioress, Chaucer's, 68

Prisons, 96, 105, 235 sqq.

Prison relics, 235 sqq.

Puritans, $\mathrm{IO}_{4}, \mathrm{II}_{3}$

Purses, 187

QueEn Victoria Street, 6o Queen's Library, The, vii

RACE-MigRATIONS, $4^{\mathrm{I}}$

Raddle, Mrs., I 84

"Rake's Progress, The," I47
Raleigh, Sir W., 109

Ramrods, 197

Ranelagh Club, 228

- Gardens, I53, I67, I99, 227-8

Rapier, Tudor, 95

Rathbone Place, I I I

Reliquary, 42

Restitutus (Bishop), 29

"Reward of Virtue, The," 224

Reynolds, Sir J., I85

Richard Cour de Lion, 46

- II, 169-70, 192

Richmond, 95

Roads, packhorse, 92 ; Roman, I6, 29

Rocking-horse, Stuart, I 30

Roman boat, 2 I 8

Rosoman, 207

Rotherhithe, $36, \mathrm{I} 67$

Rotunda, the, at Ranelagh, 228

Roubillac, I5x, I65, 229

Royal George, The, 2 io-r

Royal United Service Institution, II3

Rowlandson, Thomas, $\mathrm{I}_{47-8}$

Ruffles, 97

Ruffs, I9o

Rupert, Prince, portrait of, 76

Rushholder, rog

Ruskin, quoted, 84

SADLER's Wells, 207-8, 226

Saex, 34

St. Andrew Undershaft, $96, \mathrm{II}_{4}$

St. Bartholomew's Hospital, 28,63 , II 5

St. Giles's, Cripplegate, $x_{20}$

St. James's, I 2 I, I 44

- Coffee-house, 200

- Palace, vii, 129

- - Park, 14, 129-130, 22 x, 230 sqq.

St. Laurence Poultney, 63

St. Martin's - in - the - Fields, I64-5

St. Patrick's Cross, I 36 
St. Paul's Cathedral, first built, $35,42-3$; rebuilt, $42-3$; steeple struck by lightning, ro3-4; model of, IO3-4; rebuilt, I35, I93-4

- - Churchyard, 38

- School, 63

St. Swithin's Church, 53

Salade (helmet), 5I

Salter ("Don Saltero"), $20 \mathrm{r}$

Saltero's, Don, 5I, 20I-2

Salting, Mrs., I 46, I 49

Salvage Corps, the London, 233

Samian ware, $17-8$

Samplers, 90, I 25, 2 I 4

Sandals, Roman, 23, 26

Sardinia Chapel, 233

Saxon pirates, 22, 33 sqq.

Sceptre, toy, I 87

Scissors, 87

Scold's bridle, 237

Scotchman, shop sign, I I 5

Scott, General, 225

Scramasax, 34

Scrivener's tools, I09-Io

Scrofula, 123

Seals, $72-3$

Sebert, 43

Sedan chairs, I 84-5

Selwyn, George, 225

Sergeant's Inn, 62, 2I 8

Sergeants of the Coif, 62

Serpentine, I 4, 230

Seven Bishops, I 70

Shaftesbury Avenue, I67

Shakespeare, 19, 76, 102, I6I

Sheaths, 5 I

Shepherd, Jack, 24I

Sheridan, R. B., 225

Sheriffs, duties of, 54

Shillibeer, I77-8, 223

Ships, model of, $136-7$

Shoes, I9I-3 ; mediæval, 59 ;

Tudor, 90. See also Sandals Shop front, Georgian, 2I 4-7

Shoreditch, 95

Siddons, Mrs., 204, 205-6

Signs, shop, I I 2, I I 5, 2 I 7, 2 I9
Silk industry in London, 221

Sims, Mr. G. R., 235

Skates, skating, I 2 7-9

Skull-cup, Danish, 38

Slip (paste on pottery), 44, I 12, I 47

Sloane, Sir Hans, 201

Sly House, The, 235

Smoking. See Tobacco

Snow Hill, 167

Snuff, 217

Snuff-boxes, I 47, I 56, I 58-9, I94

Snuffers, 69-70, 223

Somerset House, 98

Southcott, Joanna, $24 \mathrm{I}$

Southwark, 3I, 39, 63-4, Io3, I 32, I8I

"Southwark Fair," I 47

Spa Fields, I67

Spain, Philip of, Ioo

Spaniels, King Charles, I29, 230

Spectator, The, 79, 194-5, I98, 200-I

Spells, I Io-I I I

Spencer, Lord R., 225

Spinacuti's monkey, 207

Spoons, 77-8, Io 7 ; Roman, 27 ; Stuart and Commonwealth, I07; Restoration, I 25

Sprimont, Nicholas, I 48-9

Spurgeon, C. W., I 72

Spurs, Norman, $4 \mathrm{I}$; mediæval, 5I, 59

"Spy," 244

Stable Yard, vii

Stabler, Mr. Harold, 86

Staff, pilgrim's, 56 ; apprentice's, 95-7

Stafford House. See Lancaster House

Staffordshire pottery, I I 2, I 72I 73,206

Staple Inn, roo

Steele, Sir R., 79, I64, 201

Steelyard, The (place), 99 
Steelyard, Gresham's, 89, 97, 99, 107

- standard, 99

Stephen, King, 46

Stepney Green, I66

"Steyne, Lord," I69

Stow, John, I I 4-5

- quoted, 60, 62-3, 97-8, I0I, $\mathrm{IO} 3, \mathrm{IO}_{4}, \mathrm{IO}_{7}$

Strand, the, 99, 103

- Palace Hotel, 223

Stuart parlour, I I2, 233

Sun Fire Office, 233

Sundial, I25

Sunshades, I95

Surbiton, I03

Surrey Gardens, 223

Survey of London, Stow's, I 14

Sutherland, Dukes of, viii, I 5

Swift, 164

Swords, Celtic, I2 ; Saxon, 34 ; lobated, 4O-I ; mediæval, 48-5I ; Stuart, I IO

Sydenham, I75

TABARD Inn, 56

Tacitus, 29

Talbot Inn, 56

Tally-sticks, 223-4

Tangye, Sir R., I 6

- Collection, II6 sqq.

Tatler, The, 79

Tea, 2I3-4

Templars, Knights, 64

Temple, the, 64,218

- Bar, 54, 98

Thackeray, I69, I82-3, 24I

Thames, 6, 9, 14, 20-2, 30, $34,38-9,6$ I, 75, I I 7, I 27-9, I 36

- bridges over. See under names of individual bridges

- Embankment, I67, I7I

- Street, 56

- Tunnel, I75

Theatres, London, 76-7, 102, I 8I, 203 sqq.

Thomson, James, ${ }^{6} 6_{4}$
Thornhill, Sir James, 24I-2

Threadneedle Street, 40, 98

Thrift-boxes, 59

Tiberius Cæsar, I9

Tiger, sabre-toothed, 4, 9

Tinsel pictures, 206

Tobacco, use of, I09, I27, I 58I 59 ; -box, I25

Tokens, I23-4

Toll-houses, I64, I66

Tompion, Thomas, I35, I 58

Top, 1 I 0

Torches, 7 I

Tottenham Court Road, 226

Touch-pieces, I 23-4

" Touching for the Evil," I23124

Tower of London, 30, 53 ; first built, 43 ; model of, $43-4$, I03, 233

Toys, 40-I, 2I 4. See also under Games, Dolls, Top

Toys of Other Days, quoted, I6I, 209

Toy-shop, Georgian, 214-7

Trade cards, 223

Trafalgar Square, 167

Trained bands, II 7, I22-3

Tree, Sir Herbert, 206-7

Trunk, leathern, I25

Turpin, Dick, 238-4I

Tyburn (Tybourne), river, $\mathbf{r}_{4}$, 63

- "Tree," I 4, 236

Tyers, Jonathan, 229

Tygs, III

Tyler, Wat, 52-3, 6I

Typhus, outbreak of, IoI-2

UMBRELLAS, I95, 227

"Unaker," I 53

Uniforms, military, I 89-90

Urns. See Amphora, Wine jar

- cinerary, 25

Vanity Fair, 169, 182-3

Vauxhall Bridge, 228 
Vauxhall Gardens, 69, I 51, I 53 , I 99, 227-9

- Stairs, 228

Velocipedes, 2 I $_{4}$

Venetian glass-workers, 88,89

Venus dish, I4I

Vests, men's, I9o

Vicar of Wakefield, The, 188

Victoria, Queen, I9, 73, I 79, 2 IO, 22I, 233 ; her costumes, 209; dolls, 209; at Great Exhibition, 175; opinion of Stafford House, vii; opens new Royal Exchange, 99; riding-whip, 209; sketches by, I74, 209; Staffordshire figure of, I72 ; writingcase, I $7 \mathrm{I}$

- and Albert Order, 73, 210

- Memorial, 22 I

- Street, 167

Victorian Order, Royal, 73

Victory, H.M.S., 77

Virginia, I I 5

"Vue optique," I 74-5

Walbrook, I4, I8, 56

Wall, London, 19, 27-9, 3I, 60,237

Walpole, Horace, 163, 225, 228

Walthamstow lake-dwelling, 7

Walton, Isaak, his house, 234

Walworth (Lord Mayor), 53

Wandsworth, 38

Ward, Leslie, 244

Ware, I 25

Warming-pan, I 12

Warrant, for execution, roo-I

Watches, 143 , I 56-8

Watch house, 243

Watchmen, 243

Waterfowl in St. James's Park, I 29-30, 230-2

Watering-pot, I Io

Waterloo Bridge, Io, I67

- uniform, I8I-3

Watling Street, 29

Wax-reliefs, I35
Weapons, I96-7

Wedgwood, I4I

Weights, 223; Roman, 25; Stuart, 107. See also Steelyard

Wellclose Prison, 243

Wellington, Duke of, $\mathrm{I}_{74}, \mathrm{I} 82$;

his carriage, $183-4,217$

Wells, Lord, 6I

- Cathedral, I56

Wesley, John, I88

Wessex, 37

Westbourne (river), I 4

Westminster, I67; importance of, 46-7, I22, I44 ; jousts at, 88, Ioo ; finds at, 89

- Abbey, I04, I58, I7O, $2 \mathrm{II}$, 2 I 2 ; building of, $42-3$

- Bridge, I0, I64, I67

- Hall, I69-70

Wheat, 25-6

White, Sir Thomas, 98

- Tower, The, 43-4

Whitechapel, II 8

- bell-foundry, I26

Whitefriars, 60, 103, 105

Whitehall, I I 8, I 2 I

- Palace, II 3-I4

White's, 225

Whitmore, Sir G., I I 5, I 16

Whittington, Richard, 63

Wigs, I90-I, I 97-8

Wig-curlers (" pipes "), I09

Wilkes, John, 163,234

Wiil, The 85

William the Conqueror, 2I2;

builds Tower, 43; gives charter to London, 45-6 ; coronation, 46

- Rufus, I69

- III, I I0, II3, I79

- IV, I79; opens London

Bridge, I70

Will's Coffee-house, 199

Wills, John, 63

Wimborne Minster, 88, I 56

Winchester, 37, I09 
Windmills, 26

Wine-bottles, I 4 I

Wine-cooler, 75

Wine jar (amphora), r 8, 24

Witchcraft, I I0-I I

Woolwich, 103, 136

Worcester, Earl of, 62

Wren, Sir Christopher, I35, I $7 \mathrm{I}$

Wrotham ware, II 2
Wyatt, Benjamin, viii

Wynkyn de Worde, 48, 55

YEOMAN of the Guard, Ioo

York, Duke of (son of George III), viii

"Yorkshire Stingo, The," I77

ZECH, Jacob, I 57 



SMITHSONIAN INSTITUTION LIBRARIES

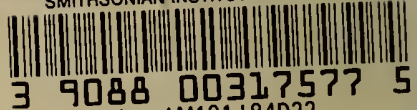

chm AM101.L84D22

The London museum / 